\title{
THE LIMITS OF CULTURAL POLICIES:THE CASE OF ART IN UZBEKISTAN
}

\author{
by
}

Kaven Baker-Voakes

A thesis submitted to the Faculty of Graduate and Postdoctoral Affairs in partial fulfillment of the requirements for the degree of

Master of Arts

in

European, Russian and Eurasian Studies

Carleton University

Ottawa, Ontario

(C) 2011

Kaven Baker-Voakes 
Library and Archives Canada

Published Heritage Branch

395 Wellington Street Ottawa ON K1A ON4 Canada
Bibliothèque et

Archives Canada

Direction du

Patrimoine de l'édition

395 , rue Wellington

Ottawa ON K1A 0N4

Canada
Your file Votre référence

ISBN: 978-0-494-83132-8

Our file Notre référence

ISBN: 978-0-494-83132-8
NOTICE:

The author has granted a nonexclusive license allowing Library and Archives Canada to reproduce, publish, archive, preserve, conserve, communicate to the public by telecommunication or on the Internet, loan, distribute and sell theses worldwide, for commercial or noncommercial purposes, in microform, paper, electronic and/or any other formats.

The author retains copyright ownership and moral rights in this thesis. Neither the thesis nor substantial extracts from it may be printed or otherwise reproduced without the author's permission.
AVIS:

L'auteur a accordé une licence non exclusive permettant à la Bibliothèque et Archives Canada de reproduire, publier, archiver, sauvegarder, conserver, transmettre au public par télécommunication ou par l'Internet, prêter, distribuer et vendre des thèses partout dans le monde, à des fins commerciales ou autres, sur support microforme, papier, électronique et/ou autres formats.

L'auteur conserve la propriété du droit d'auteur et des droits moraux qui protège cette thèse. $\mathrm{Ni}$ la thèse ni des extraits substantiels de celle-ci ne doivent être imprimés ou autrement reproduits sans son autorisation.
In compliance with the Canadian Privacy Act some supporting forms may have been removed from this thesis.

While these forms may be included in the document page count, their removal does not represent any loss of content from the thesis.
Conformément à la loi canadienne sur la protection de la vie privée, quelques formulaires secondaires ont été enlevés de cette thèse.

Bien que ces formulaires aient inclus dans la pagination, il n'y aura aucun contenu manquant.

\section{Canadä}




\begin{abstract}
This thesis chronicles the evolution of USSR cultural policy on paintings in Uzbekistan primarily from 1930 to1960. The author asserts that a gradual transformation in Uzbek paintings took place between these dates with fluctuations of influence accelerating in the post-World War II period and beyond. It is the first major post-Soviet study to consider the impact of Soviet cultural policies upon Uzbek painting's direction and imagery during the height of socialist realism. The study draws upon theoretical works of Edward Said and Stuart Hall providing an in-depth analysis of painters' interactions both within Uzbekistan and throughout the Soviet Union. The goal of the thesis is therefore to contribute to greater understanding of the way in which policy was interpreted and presented in the Uzbek SSR, while raising issues for future research on the subject.
\end{abstract}




\section{Acknowledgements}

I believe now having worked on and completed this project that I finally understand when peers have said that the thesis or research paper is as much a test in patience and perseverance as it is a joy to research and write. We are forced to find a balance between writing and - perhaps most difficult - time to reflect on the research and findings. Writing a thesis is not easy and it is not meant to be.

Along the journey we receive help from our advisor and others who selflessly give their time to help make our projects a success. I list only a few with the knowledge that there are countless more too numerous to name: to all I can only say thank-you.

My own advisor - Professor Jeff Sahadeo - I owe so much for not only serving as a great sage during this project, but also as one of the main reasons for my entrance into the program. Professor Sahadeo's continual support and recommendations especially in the initial stages of this thesis have been most invaluable.

I also have a debt of gratitude to my Theory and Methods graduate class who helped flesh out ideas and provided feedback and criticism for the project as it was being conceptualized. The professors who led that class - Piotr Dutkiewicz and Andrea Chandler served as guides for all of us in that room and I consider it a privilege to have been within that classroom setting with those two noted scholars.

Finally, I wish to thank the EURUS department as a whole for their willingness to raise an undergraduate student into a Masters candidate. I can only hope that this small contribution will satisfy the trust and faith shown to me throughout my studies. 


\section{Table of Contents}

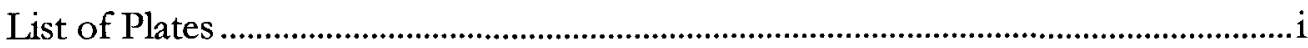

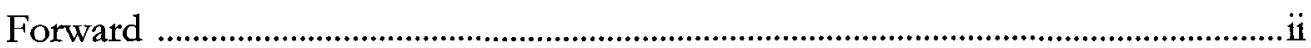

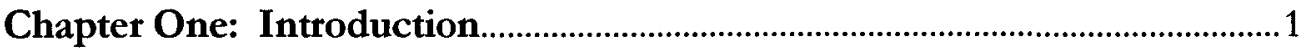

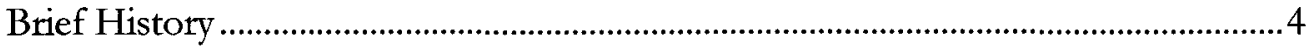

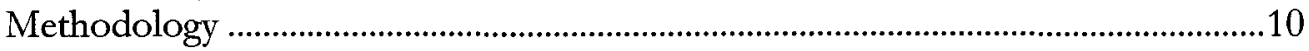

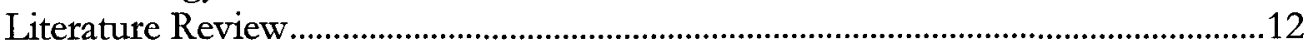

Formalism and Cosmopolitanism Vs Socialist Realism ......................................17

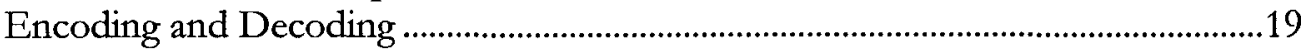

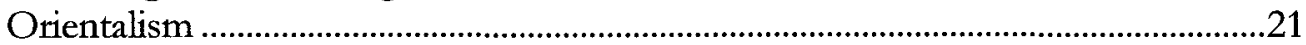

Chapter Two: Outside Influence and Exchange Pre-Conquest Period ......25

Nineteenth to Early Twentieth Century Influences...................................................31

Developments in the Late Tsarist Period ...................................................................34

Chapter Three: Early Russian Revolution Period .............................................37

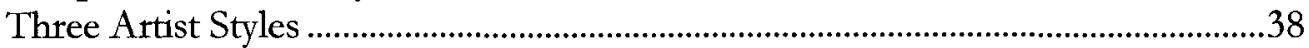

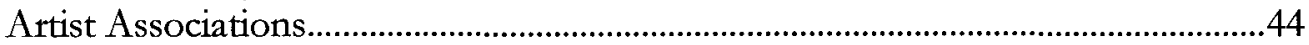

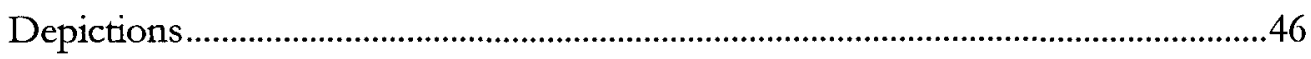

Chapter Four: The Socialist Realism Revolution 1930-1935 …....................50

Creating Socialist Realism .........................................................................................51

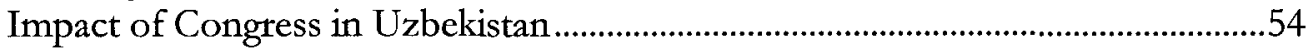

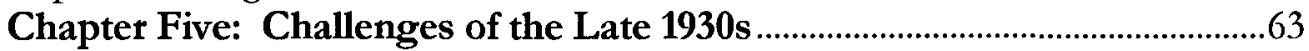

Artists Arrests and Promotion ...................................................................................63

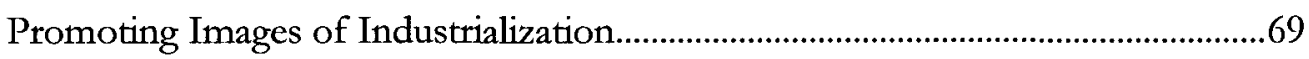

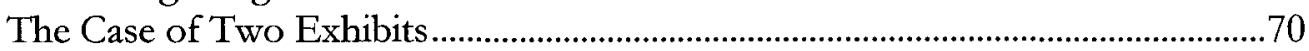

Chapter Six: From Moscow to Tashkent: Interactions During

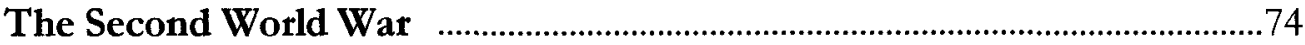

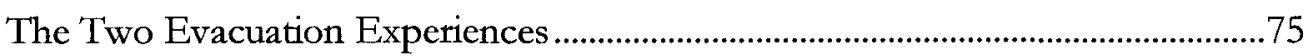

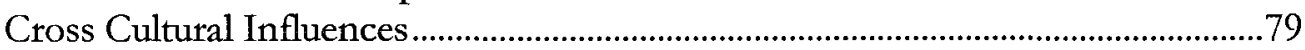

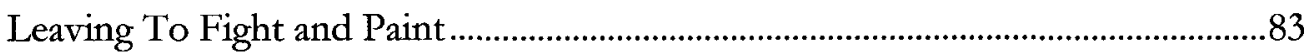

Chapter Seven: Zhdanov and the Anti-Cosmopolitan Campaign ..................87

Creating A New Art In Uzbekistan .........................................................................91

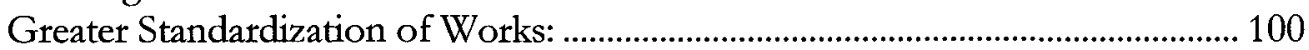

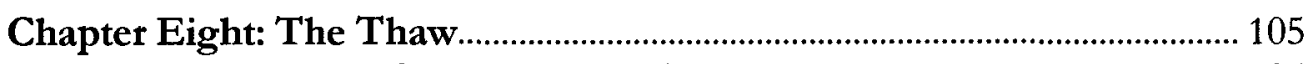

Changing Directions Before Stalin's Death:.................................................................. 106

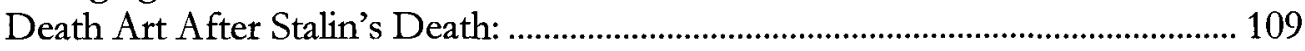

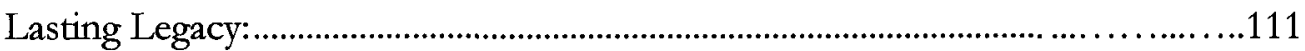

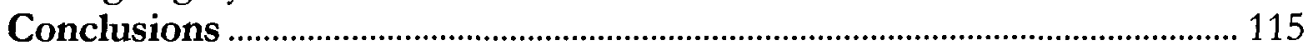

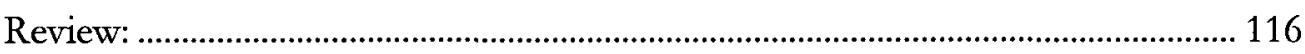

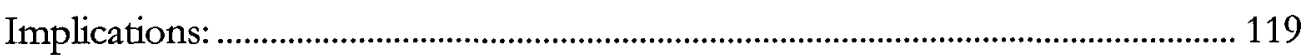

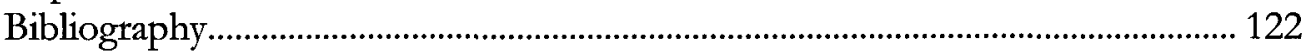

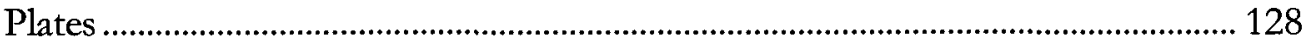




\section{List of Plates}

Figure 1 Untitled, Panel, Guache, Late 19th century to 20th

Figure 2 Tatevosyan Oragnes Karapetovich, Village, 1919

Figure 3 A Volkov, Cotton Girls, Oil on Canvas, 1939-1940

Figure 4 A Volkov. Artba (Uzbek Cart), Watercolour on paper, 1919

Figure 5 Ural Tansikbayev Crimson Autumn Oil on Canvas1931

Figure 6 Shamsroi Khasanova, Portrait of Matraba, Poetess of Kashgar, Canvas

Distemper, 1947

Figure 7 N.V Kashina, Lunch-time, Oil on Canvas, 1949

Figure 8 Abdulhak Abdullaev, A. Hidoyatov, in the Part of Othello, Oil on canvas, 1946

Figure 9 Ural Tansikbayev, Collective Farmscape Oil on Canvas, 1958

Figure 10 N.V. Kashina, Italy in the Khumsam (mountains in the Tashkent region), 1957

Figure 11 S.F Abduallaev, In the studio of Master Usman Zufarov, Oil on Canvas, 1958

Figure 12 N.V. Kashina, A Small Skull Cap, Oil on Canvas, Wax 1960 


\section{Forward}

In Canada, as in much of the modern democratic Western world, it is difficult for us to fully understand or comprehend government control and censorship in art. Art, by its very nature, has pushed the boundaries of social understanding as a commentary of our society for the better part of the last hundred and fifty years. Art in modern Western democracies has been rarely restricted by government in the manner and degree it was in the USSR and other communist states. Therefore, from a Canadian perspective, any interference or limitations that may be restrictive to art is considered repressive in comparison to our own experiences.

I would therefore encourage readers to look past the obviously restrictive wording of the policies of this regime that this paper discusses. Instead, I ask that the reader consider the broader implications of the implementation and expectations that the USSR governing elites had with respect to the obedience of subjects towards these policies.

Only by reviewing the artworks from the perspective of artists operating under the Soviet perspective and control can the reader truly appreciate the questions and answers which this thesis proposes.

Kaven Baker-Voakes 


\section{Chapter One: Introduction}

It's probable that never was the range of subjects and people so limited as in the 1930 s and 1950 s.

- Introduction from art exhibit catalogue "Agitation for Happiness." 1

The above quotation is from a notable 1994 art exhibition held in St. Petersburg, Russia and Cassel, Germany that presented one of the first post-Soviet evaluations of Soviet art from the 1930 s to 1950 s. The exhibit, cited in numerous papers and books as one of the largest and most complete of its kind, allowed outsiders a first glimpse into artworks produced during the height of Stalin's power. The exhibition featured an array of works, many of which served to capture the time period and the use of art as a tool of propaganda. The display even included the rarity of a porcelain sculpture with human figurines from Central Asia discussing Stalin's 1936 constitution. ${ }^{2}$ The highly political nature of this and other pieces was not limited to the medium of sculpture - similar undertakings would appear in paintings from the region as well. This thesis examines the Central Asian region of the Soviet Union, concentrating on Uzbek paintings that displayed this art form in the 1930-1960. It reveals a fascinating story, demonstrating how policies and events within the Soviet Union produced unexpected outcomes in paintings. This period marked the height of socialist realism. Unlike traditional or realist based art, socialist realism carried with it several major assumptions, with the foremost being the reasoning behind the creation of art. The 'purpose' of socialist art for the regime was to create an art which was understood by a wider audience by drawing on ideas familiar to the audience such as everyday activities. Moreover it was to aid in the

\footnotetext{
${ }^{1}$ David Ljunggren, "Art show dusts off works used to paint over Stalinism's cracks," 24 April 1994, Reuters News.

${ }^{2}$ Ibid.
} 
creation of a new citizenry who would have a greater understanding of the world in which they interacted.

This thesis asks, "To what extent did socialist realist policy affect paintings in Uzbekistan from 1930-1960?" It argues that the policies behind socialist realism were a set of varying, inconsistent ideas, in tension with each other over time and demonstrating that socialist realism's definition was not fixed. In so doing, it challenges popular conceptions of the period that places an emphasis on policy alone as the primary driver of art production in the region. Instead I argue that works of art were influenced by an array of factors ranging from officials, painters - both within the Union and abroad- then finally government policy. Over the course of this study my assessment actually rejects the notion of an authentic art form in the region. Instead, based on my own research on the region I find miniatures and then European styles were susceptible to changes over time creating a hybrid in the process. This pattern of blending works never really ceased, but continued into the socialist realism period. Further, the study will examine whether the guiding hand was truly the direction that Uzbeks had requested.

With respect to methodology, the main reason for selecting paintings was that much of the previous work conducted by scholars on Uzbek art during this period has concentrated almost exclusively on writing, music and dance. Aside from Bown, ${ }^{3}-$ who has mapped the entire non-Russian region's paintings ${ }^{4}-$ to my knowledge no

\footnotetext{
${ }^{3}$ Bown's work is one of the first evaluations of the "non-Russian" republics painters after the declaration of an independent Uzbekistan. See. Matthew Cullerne Bown, "Painting in the Non-Russian republics," in Art of the Soviets: Painting, Sculpture, and Architecture in a One-Party State, 1917-1992, ed. Matthew Cullerne Bown, et al.(Manchester: Manchester University Press, 1993).

${ }^{4}$ Khakimov's paper on art education in Uzbek is another contemporary study, however it is extremely limiting as the author contrasts the past (starting in the Tsarist period) to the present failing to address major historical periods in detail. See Akbar Khakimov "Art Education in Uzbekistan" in L. Joubert (ed.)
} 
comprehensive study in the post Soviet period has examined the whole of Uzbekistan's paintings and its relation to socialist realist policy between 1930-1960. Studies that have been undertaken concentrated on individual artists rather then taking a holistic approach to examination and were more often biographical in nature. My own study provides an unusual opportunity to contrast policy and art over this period. This study utilized different artists' works to demonstrate contrasting creative styles from those who interacted with each other during these years despite their stylistic differences. The thesis charts the lives of painters past a singular period demonstrating how their lives changed and were impacted by both policy and other artists alike. The benefit of taking a holistic approach is that I am able to draw greater general understanding of the period and determine if there were any unique experiences among painters.

The thesis consists of nine chapters: a brief background in the first chapter, then an examination of several time periods in the subsequent seven chapters with a final chapter summarizing the total paper. The intent of the writer is to provide the reader with a greater understanding of the topic and to encourage further scholarship in a field rarely examined. In order to put these themes into the proper context a brief history of major events at the turn of the century in Uzbekistan will anchor our discussion. Through this brief history, an understanding of major events and the correlation between paintings is established- enabling more detailed discussions throughout this study.

Educating in the Arts - The Asian Experience: Twenty-Four Essays, (Dordrecht, the Netherlands: Springer Science + Business Media B.V, 2008). 


\section{A Brief History of the Region}

Uzbekistan, an independent state as of 1991, is notable for its geopolitical position. The area, with cities on the Silk Road, was exposed to constant cultural influences both in trade and military terms throughout its history. Miniature painting-a type of art form to be discussed in this thesis - emerged as a result of these interactions blending influences from cultures in the region. These interactions became especially important during the "Great Game"-a battle for control between the British holdings in India and the Tsarist Empire in the Nineteenth Century. Russian and British agents vied for power in the important cities of Bukhara and Kokand with the Tsarist Empire eventually winning control of the region with its military campaigns of the late Nineteenth Century. During this period, people living in the region did not regard themselves as Uzbeks, but generally identified themselves by religious affiliation or by the town where they lived - that is, identity was more local and cultural-religious than nationalist in scope. ${ }^{5}$ In Tsarist Russia as well as the Soviet era, the administrative capital was placed in the trading centre of Tashkent. Tashkent served both as a base for Tsarist expansion and as an ideal city envisioned by planners. In fact, two cities were constructed side-by-side; this allowed for Euro-Russian visitors to compare their new "civilized" city with the old "backward" Tashkent ${ }^{6}$.

Small socio-political clubs and even a few informal Tsarist schools, which promoted Russian art, began appearing in the cities- notably in Tashkent, where the famous Khiva theatre was constructed in 1910. By the end of 1919 there were 177

\footnotetext{
${ }^{5}$ Laura Lee Adams, "Celebrating independence: Arts, institutions, and identity in Uzbekistan". (Ph.D. diss., University of California, Berkeley, 1999), 53.

${ }^{6}$ Jeff Sahadeo's study Russian Colonial Society in Tashkent 1865-1923, explicitly discuses the interactions within the city or rather cities. See Sahadeo, Russian colonial society in Tashkent: 1865-1923.

(Bloomington: Indiana University Press. 2007), 80-90.
} 
libraries, 97 clubs, and 172 reading rooms, in Turkestan. ${ }^{7}$ The opening of new institutions in the region was in part a result of a Tsarist policy of training a new intelligentsia within the colony. ${ }^{8}$ In 1924, the Soviets delimitated territories for each ethnic group that they believed existed in the region, including the Uzbeks. Its distance from Moscow during Soviet times meant central government policy enforcers had to often had to rely upon reports with few actually having visited the region for any given length of time.

Correspondingly, as a host of scholarly studies have pointed out the partitioning of the region into Republics was directly linked to the Soviet vision of nationalization. In dividing Central Asia into separate national groups-each with its own territory- the Soviets were forced to create or more accurately imagine identity markers, which would denote differences between the various groups. National costumes became important identifiers of nationality within paintings even though costumes did not always capture the realities of dress within the republic, often outdated and depicting images that advanced state goals.

This seemingly contradictory goal of defining peoples, while creating a unified state in fact played out throughout the entire history of the USSR. It combined with other themes - including the setting of Russians on a higher level compared to the "nonRussians."

Samarkand became the capital of a new Uzbek Soviet Socialist Republic from 1924-1930, thus explaining in part the influx of painters to the city over Tashkent. In 1930, Tashkent would become the new capital of Uzbekistan, and the fourth largest city in the USSR. The new capital also became a chief rival to Samarkand-the region's

\footnotetext{
${ }^{7}$ I.M. Muminova, Uzbekskoi SSR, (Tashkent: Institut Istorii, 1974), 293. (hereafter cited as UzSSR).

${ }^{8}$ Akbar Khakimov, "Art Education in Uzbekistan," 182.
} 
previously accepted centre of the arts, with many institutions based in Samarkand primarily due to its previous influence.

In spite of official rhetoric of recognizing other nationalities, in the mid 1920s the Soviet authorities initiated the Hujum campaigns, which aimed at eliminating the use of veils worn by Muslim women. ${ }^{9}$ The campaigns focused on Communist Party officials, whose wives, it was claimed, needed to unveil if they wished to continue with the Party. Some women quit the Communist party in protest, becoming targets during the Great Purges for refusing to follow the party line. Uzbek women given the choice between the Communist party and veiling overwhelmingly rejected the communist party. However, despite the fact that many women chose the veil, my research reports that paintings of this period only depicted women without veils, thereby supporting the myth of Uzbeks conforming and "progressing" as expected and in accordance with Soviet policy.

In keeping with the transformations of post-revolutionary society, collectivization campaigns also had a major impact on the Republic during the early 1920s, with cotton collection and industrialization sweeping the Republic. The Soviet collectivization campaigns that began in 1929 proved to be disastrous for the Uzbeks, not only in terms of their long term ecologically impacts, ${ }^{10}$ but also in terms of a human dimension with clashes between officials and Central Asians. Canals began being built across the country to irrigate farm fields so that the Republic could harvest cotton - or as it was referred to at the time "white gold". Besides canals other projects including the building of dams and

\footnotetext{
${ }^{9}$ Marianne Kamp, "Pilgrimage and Performance: Uzbek Women and the Imagining of Uzbekistan in the 1920s," International journal of Middle East Studies 34 no. 2 (2000): 267-273.

${ }^{10}$ The Aral Sea, one of the world's largest fresh water lakes, was effectively destroyed as water was diverted through canals that were constructed beginning in this period to water cotton crops. For a complete description of the events surrounding the Aral Sea disaster see P. P Micklin, "Desiccation of the Aral Sea: A water management disaster in the Soviet Union," 241: 1, Science (1988): 170-76.
} 
reservoirs were also built all connected to cotton production, with a final goal to make Uzbekistan the premier place for cotton production in the USSR. These developments coincided with the advent of socialist realism and officials encouraging the depictions of these changing "realities". The capturing of these events within paintings allowed for the Soviets to expound the benefits of the socialist system and their role in creating a new communist state. The cultivation of the valuable material remained a labour intensive industry. Subsequent analyses of cotton production would contain contradictory explanations, described as wholly inadequate and destructive or the great accomplishment and a demonstration of achievement and pride for the Uzbek people.

Furthermore, as the Soviet Union entered the 1930s the challenges of previous years began to surface. The results were attempts by the regime to establish common directions across the union combining a wide geopolitical union spanning massive territory. In art circles this meant first a 1932 declaration of unity amongst the various art organizations, creating singular artist groups, called unions.

These non-independent unions in turn each supposedly represented specific regions and specific art forms. One such union-the Writers Union-was able to consolidate faster than others and held a congress (1934) proclaiming Socialist Realism as the Soviet Union's art form. The other artistic mediums - including paintings - were forced to follow the newly declared art form. However, the discussions at that Writers Union congress suffered organizational problems, causing confusion in the application of socialist realism in the years that followed.

The 1930s art form was perhaps most importantly to be "nationalist in form, socialist in content." The national form was directly linked to the newly-created 
Republics, while the socialist content represented the union as a whole. In theory, artists were allowed to create works that contained national imagery, as long as it also contained socialist messages. The problem would be defining what precisely this meant and how it would be carried out. Like many statements the initial declaration of this USSR policy was vague allowing for a degree of interpretation both by officials and by artists themselves.

During the 1940s the Soviet regime promoted the idea of the friendship of the peoples (druzhba narodov). The phrase used by Stalin was part of a formalized campaign that aimed to promote a harmonious relationship between various nationalities within the Republics under a Soviet roof. ${ }^{11}$ Officials declared that all the nationalities within the Union had overcome past differences and that only mutual respect for one another prevailed. ${ }^{12}$ At official meetings symbolic paintings depicting delegates smiling and greeting one another as Stalin looked on became commonplace. The friendship is also important to note given its direct relationship to art - mainly the promotion of Russian works over Uzbek ones.

The efficacy of propaganda in achieving the regime's goals was evident during the Second World War. Over four hundred thousand Uzbek men fought. ${ }^{13}$ Artists were sent to the front to document the war efforts, and many did not return. In Uzbekistan during the war buildings were converted into factories, the country's populace was displaced, and the Republic also received an influx of refugees from Russian cities and Eastern European Soviet areas.

\footnotetext{
${ }^{11}$ Terry Martin, The Affirmative Action Empire: Nations and Nationalism in the Soviet Union, 1923-1939, (Ithaca and London: Cornell University Press, 2001), 339-344.

${ }^{12}$ Ibid., 339-344.

${ }^{13}$ Ibid., 339-344.
} 
In the postwar period soldiers returning from the front were met with a radically altered society. Economic and demographic conditions in the Republic were significantly changed, owing in part to an increased level of participation of women in the work force and an increased presence of people from other parts of the Union. In addition, the returning soldiers had gained greater language skills in Russian and closer ties to the Communist party. The artists who had travelled to document the war also reflected this increased interaction, with works that were closer to official expectations. Party ranks during the period swelled as a result of the newly arrived soldiers. The campaigns of modernization of cotton production began to take place in the Republic from 1950 onward. Tractors and machinery equipment become highly visible in the foreground of paintings, reflecting the changes of the era. Stalin's death in 1953 caused political shifts in Moscow, but the shift between the central leadership did not change rapidly overall. However, with the post-Stalinist "thaw" in the mid 1950s, Soviet relations with other countries began to improve. Khrushchev and other officials encouraged interactions with countries to the East of Uzbekistan in Asia and as well as with Africa. It was claimed that the various peoples could learn from the advances that had been accomplished within Central Asia and specifically in Uzbekistan's capital Tashkent. ${ }^{14}$ The promotion of development offered by the Soviets led to displays of Uzbek culture abroad with various arts especially dancers being sent to instruct in the Middle East and parts of Asia. ${ }^{15}$ The final result of the era was indications of increased levels of freedom for artists and citizens across the Union. The final period to be examined is 1953-1960, which includes two major events the first Stalin's death in 1953 and the second the all

\footnotetext{
${ }^{14}$ Adams, "Celebrating Independence."

${ }^{15}$ Ibid.
} 
Union show of 1960, which displayed some of the major art works undertaken in the 1950s.

\section{Methodology}

The construction of this thesis is based on a comparison between two sets of variables: 1) policies or statements of policies and; 2) paintings undertaken by select artists and the reactions to those works. This framework is based on the work of Stuart Hall, whose encoding and decoding methods will be discussed in further detail in the following sections. The study compares these two variable sets with an emphasis on the ways in which painters interpreted the meanings of the messages the regime sought to advance.

The selection of the specific artists is based on a determination of major Uzbek artists of the time, whose works are currently accessible through museums. My own visits to the Nukus Museum, Samarkand Museum and Tashkent Fine Arts Museum all contributed to the selection process of both artists and artworks discussed. The visual inspection of the pieces was necessary since this paper discusses colour as a major component of the criticism and praises of Uzbek works. It also allowed for my own independent evaluations of the paintings. Further, my time at the Nukus museum allowed for consultation of an extensive library devoted exclusively to the subject of Uzbek art. Many of the books from that library have been instrumental in this thesis's construction since they are not readily available in North America.

The final determining factor that led to artists' selection was based on a combination of the above criteria and documents, as well as books published at the time. The primary artists I selected are Pavel Benkov, Alexander Volkov, Ural Tansykbaev, 
Usto Mumin, Mikhail Kourzin, Organes Tatevosyan, and Bahram Hamdam. These painters are identified as representatives of the visual arts of the Republic, whether from Uzbekistan originally or having journeyed to the Republic. ${ }^{16}$ In addition to being prominent at the time they were highly influential either through direct instruction or indirectly guiding artists in the major centers of the country. Despite their positions of prominence the artists who I have selected often faced periods of extreme criticism. The preservation of these artists' works, when undertakings of their peers were destroyed, was due in no small part to the importance that the works held at the time. Among this primary group of painters, Volkov and Benkov in particular illustrate successes and challenges experienced by artists throughout the thirty year period. Besides these primary artists, I also make note of other creators throughout this study. Often students of these influential painters, they include-but are not limited to - S.F Abdullaev, Shamsroi Khasanova, Kaydalova,V. Fadeev, L. Addullaev, Karahan, and Abdulhak Abdullaev. Besides paintings at the galleries of Uzbekistan and Russia I also made use of a variety of primary materials found in publications directly relating to the artists. These publications, printed nearly exclusively by Uzbekistan's Artist Union, were common following the death of an artist and incorporated items ranging from letters, correspondence, awards and personal reflections. The books also contained commentary from other artists who knew the painters and their own recollections and stories involving them. These documents along with the paintings were used throughout this study as examples of the reaction to the various policies and were imported into the modified Stuart Hall framework to be discussed shortly.

\footnotetext{
${ }^{16}$ The painters Pavel Benkov, Usto Mumin and Mikahail Kourzin all journeyed to Uzbekistan from other locations, primarily in Russia.
} 
The thesis also utilizes written policy, party official speeches or statements instead of only citing policy. I have undertaken this approach for several reasons, the first being that actions were undertaken often due to these particular speeches. The second reason is the lack of a concrete singular policy to cite. The historian Shelia Fitzpatrick has observed that many Western and Soviet historians alike have been "puzzled" at how party officials claimed to have mandates over culture. ${ }^{17}$ These claims of power were made even when nothing was actually published or ever recorded, which allowed for such statements. ${ }^{18}$ In my own research I have noted this occurrence in books or magazines of the time which reference Stalin without citing specific times, places or documents when he made alleged guiding statements.

The importance of speeches and statements greatly influenced my own approach to the research, as I cite commentary by officials or critics rather than exclusively documents. As I will discuss over the course of this thesis Soviet statements could become policy and be used as a personal political tool.

\section{Literature Review}

The major questions associated with the study of socialist realism have focused on two main aspects; first, how exactly it functioned: and, second, the art it produced. The success of the policy in most cases is assumed. In my study of both of these questions, I have taken a more contemporary approach of an unfixed definition of socialist realism, instead viewing each definition given by an official as its own time-specific event. This approach allowed for a nuanced understanding of socialist realism policy and did not, in contrast to other works, create a fixed definition.

\footnotetext{
${ }^{17}$ Shelia Fitzpatrick, The Cultural Front, (Ithaca and London: Cornell University Press, 1992), 138. ${ }^{18}$ Ibid.
} 
Most studies of socialist realism in art originate from the Soviet period such as Istoriia iskusstva narodov sssr (The History of the Art of the Peoples of the USSR) by Vemarha and Zehgr and The Art of Soviet Uzbekistan by Umarov and suggest that a sudden change occurred within art between 1932 and 1934. The authors note, among other changes, that more historical and heroic figures began appearing in Uzbek paintings. ${ }^{19}$ These books, published in the USSR, not surprisingly give the impression of a successful socialist realism policy, which the Soviet Union was responsible for producing. They cite examples of "progress" appearing in the paintings, mainly cotton production and farming- as modern methods of painting are introduced. These works in fact downplay the existence of a set policy that was directing the Republic at the time instead making it sound as if the changes were spontaneous and natural. Nonetheless they do acknowledge a guiding hand from Moscow, which according to the accounts only provided the direction which the Uzbeks had requested.

The writing understandably produced similar results among later scholars of the period, who emphasized the controlling nature of Moscow in Uzbekistan. This influence can be observed in writings of authors such as Akbar Khakimov, a contemporary Uzbek writer who has pushed for the concept of a successful Soviet policy toward art. Khakimov has argued that art from the 1930-1980s reflected the wishes of the state, as works and instruction were adjusted to suit dictated policy acknowledging at the same time that some limited artistic freedoms were exercised.$^{20} \mathrm{The}$ socialist realist policy, according to Khakimov, was therefore successful in both its application and results. Similarly, Khomutov's article, "Painting and Drawing of Uzbekistan" argues that the

\footnotetext{
${ }^{19}$ Umarov Adulakh Rashidovich, The Art of Soviet Uzbekistan, (Leningrad: Aurora Art Publishers, 1972), 28 and $U z S S R, 397$.

${ }^{20}$ Khakimov, "Art Education in Uzbekistan," 182.
} 
natural development of art in Uzbekistan was interrupted with the advent of socialist realism and did not reemerge as a nuanced, or substantively different, expression of its former self until after the collapse of the USSR.

Meanwhile, scholarship from outside of the Republic has produced slightly varied results. Mathew Cullerne Bown's study of non-Russian Republics describes the way painters were able to circumvent some of the desires of the state in the non-Russian Republic. He discusses a number of painters from various Republics. The result is a number of sweeping statements. The first concerns his contention that "the Muslim Republics had no tradition of Western-style figurative art." ${ }^{21}$ The problem is that Bown ignored the possible interactions that could have occurred prior or even during the Tsarist period. A second point Bown argues is that the war period had limited impact on paintings in the country. Similar to my own conclusions, he points to the 1950s as the key turning point in creating "homogeneity" ${ }^{22}$ However, Bown's study does not speak to important debates and tensions that existed in the period. My own study aimed to address this shortcoming of scope by sharpening the analysis to only one Republic: Uzbekistan. The result is a further elaboration on some of Bown's own conclusions, as well as several new ones based upon closer inspection of works.

In contrast to Bown, Edward Allworth's work on Uzbek literature has demonstrated how nuances are important in our understanding of how policy was implemented. The works draw our attention to the role that local elites played in the successful implementation of policy and how nationalist policies, such as the "Friendship of the Nationalities" intermeshed with the desires of socialist realism. Allworth discusses

\footnotetext{
${ }^{21}$ Bown, "Painting in the Non-Russian republics,"145.

${ }^{22}$ Ibid., 151.
} 
how elites were successful at persuading officials of the challenges that faced literature. Allworth's own reading of the events seems to be that Uzbeks opposed or created in literature a counter movement from the Soviet model. In part, this is based on a coherent understanding of Uzbek identity, which Allworth assumes, but of which I am not entirely convinced. Nevertheless, his work is helpful in establishing the importance of nuance, which compared to other works, is dealt with in far more in-depth. It provides key dates for events, which are severely lacking in other studies that examine socialist realist events. This study borrows the idea from Allworth's works that generalized assessments, such as Bown's on Volkov, can give a false picture of the events of the period. By discussing certain individual's lives over a prolonged period, we can gain a greater idea of the interactions between local artists and policy.

More recent studies conducted by Mary Doi, Laura Adams and Tomoff have pointed out that while the Soviets created national culture within the Union as a whole; they also created a uniquely indigenous interpretation of the policy. These conclusions closely link to my own examination, which aims to examine the localized art forms. Doi studies the changing nature of dance in the Soviet and post Soviet eras and its evolution, or in her words, "elaboration, nationalization and standardization". Elaboration was the discussions of the types of dances, while nationalization was the promotion of the idea that a national form existed throughout the Republic. Finally, standardization was the introduction of specific learned techniques that would define dance within certain regions and by certain characteristics. Doi's study notes how regional variations were categorized by the Soviets, including such categories as Bukharan and Fergana. These regional categories were connected to the nation-building exercises that the Soviet were engaging 
with during the period. Although my own study does not find evidence of highly localized categories of specific styles it does find evidence of specific identity constructs based on imaginings of "Uzbek" appearances and habits.

Studies of music have also drawn similar conclusions concerning a classification of Uzbek music styles. Tomoff writes about the Soviet identification of four distinct regional styles: Khorez Bukhara-Samarkand; the Fergana Valley; Tashkent and Surkhandaria-Kashkadaria. ${ }^{23}$ The styles were according to Russian musicologists distinct in sound, but would have all been classified as folk music melodies. Even Paul Stronski's description of rooms based on Uzbekistan's six major regions in the Navoi Theater in Tashkent seems to suggest a desire to further classify different components of the Republic. ${ }^{24}$

Tomoff's work Uzbek Music's Separate Path: Interpreting "Anticosmopolitanism" in Stalinist Central Asia, 1949-52, which examines the impact that Soviet policy had on Uzbek music, argues that the artists pursued different interpretations of the policy using it to promote indigenous forms of music. The promotion of indigenous music caused concern for officials in Moscow since they believed the local Uzbeks were promoting the incompatibility between the West and the East. ${ }^{25}$ The result of the promotion by local elites of the dated forms and the nationalized concept was a push by Moscow for the standardization of music to use Doi's terminology.

\footnotetext{
${ }^{23}$ Kiril Tomoff, "Uzbek Music's Separate Path: Interpreting "Anticosmopolitanism" in Stalinist Central Asia,1949-52," The Russian Review, Vol.63, No.2 (April 2004), 224.

${ }^{24}$ Paul Stronski, Tashkent Forging A Soviet City 1930-1966, (Pittsburgh: University of Pittsburgh Press 2010), 165.

${ }^{25}$ Tomoff, "Uzbek Music's Separate Path," 240.
} 


\section{Formalism and Cosmopolitanism versus Socialist Realism}

Throughout the thesis, I use the terms cosmopolitanism and formalism, which were employed at the time by various state officials to describe painting methods that did not fit the described socialist realism. Formalism was used to describe non-conforming art primarily from the early 1930 s to the mid 1940 s, while cosmopolitanism 26 came into use in the late 1940s continuing until the mid 1950s. Formalism for the Soviets was conceived as being a personally based abstract art with form rather than content emphasized. The art with its emphasis on an individual's interpretation meant that a painter's perception was independent of social or political factors.

State officials as previously discussed State officials desired to create a form to educate the masses and instill revolutionary sentiments, as such creations needed to follow a strict guideline to fulfill these goals. The formalists' abstract form meant that they could not align with those policies, which sought a more conservative form mimicking Russian art of the past. Vladimir Kemenov, a Soviet art critic and one of the proponents of Socialist Realism, would write:

A formalist uses all possible means to distort the pure image of the Soviet people who engage in building communism. A formalist deforms, distorts the face...conducts a horrible dissection of the face and body of the human being. This program of militating ugliness is clearly an insult to people (and) in our society. ${ }^{27}$

Perhaps what is most interesting in the statement is that it specifically cites the need for a clear image of the face and the body. The distortion of the face for the Soviets would fail to demonstrate the reality that they hoped to portray of happy and smiling

\footnotetext{
${ }^{26}$ The term used was used in the 1940s by the Soviets to denote foreign (capitalist) styles in artworks, which were outside of Socialist Realism aims.

${ }^{27}$ Maria Bulanova and Alla Rosenfield, Soviet Disunion: Socialist Realist \& Nonconformist Art, (Minneapolis, MN: Museum of Russian Art, 2006), 21.
} 
citizens. ${ }^{28}$ The comments were directed against avant-garde painters, whose works would fail to present the ideal Soviet man.

The Soviets, therefore, issued the threat of reprisals for a lack of conformity via its various government bodies detaining and arresting artists and banning work that did not conform to its vision. The attack on formalist painters in the early 1930s laid the groundwork for much of the criticisms of cosmopolitan art in the late 1940s to early 1950s. Some scholars such as Tomoff in fact use the terms interchangeably since they argue the result was the same.

In contrast to formalism, the unsanctioned art of cosmopolitanism was part of a much broader form of criticism. Officially, cosmopolitanism-as the term suggestsreferred to artists of a worldly outlook with influences from abroad. However, unlike its contemporary connotations the Soviets feared its citizens were undermining the Soviet project. Unofficially, as many researchers have noted it was veiled anti-Semitism. ${ }^{29}$ Starting definitively in 1948, although small campaigns have been noted in the past, Stalin and other officials launched attacks against the "anti-patriotic" cosmopolitan interlopers in their midst. ${ }^{30}$ Stalin captured the goals best in his famous statements linking Jewish nationals and the United States, claiming Jews were spies for the Americans. As a result Jews associated with cultural institutions ranging from theatres to film productions were disproportionately targeted compared to other Soviet citizens.

\footnotetext{
${ }^{28}$ The paintings of smiling citizens were less common in the early 1920-1930s works in Uzbekistan than in the 1960s.

${ }^{29}$ Tomoff, "Uzbek Music's Separate Path," 212.

${ }^{30}$ Ibid., 212-114.
} 
Other artists, who also fell under the category of cosmopolitanism, were those who allegedly promoted nationalism over the socialist agenda. ${ }^{31}$ In Uzbekistan, the campaigns seemed to have been focused on this group in particular, with musicians and writers specifically targeted. This is not to suggest that Jewish citizens were not targeted as well. Max Penson, one of the more important photographers in Uzbekistan, left his profession in the post world war period out of fear. During the anti-cosmopolitan campaigns, accusations were made against cultural institutions that they were only promoting music and literature from the fourteenth century or earlier, at the expense of contemporary work. Interestingly, no mention is made to miniature art works or other past visual art forms, although references to patterning and primitive undertakings can be clearly found in Soviet officials statements from the period. These statements (along with the negative consequences of them) defined the late 1940s. The theoretical elements discussed in this chapter will be used as part of the analysis in the following chapters.

\section{Encoding and Decoding}

The cultural theorist Stuart Hall's seminal work on encoding and decoding was instrumental in most of this theses' construction. Hall's work addresses primarily our interpretation of events and examines the filters that are used to describe the particular event that leads to its interpretation. Hall's notion of communicating differs substantially from more traditional forms, which argue a linear path of message sender and receiver exists. Hall instead explains the path follows the encoding of the message, sending of the message, receiving of the message and the decoding of the message.

\footnotetext{
${ }^{31}$ Tomoff, "Uzbek Music's Separate Path," 212-214.
} 
The "source" or encoders undertake their own discourse, which includes the way they want an event ${ }^{32}$ or message interpreted. ${ }^{33}$ The idea, along with the event, is then sent through a different medium to the respective audience. The initial encoding step is important to understand, but this thesis' primary interest is in the decoding. Hall proposes three possible outcomes for decoding of the "moment" or event. The first decoding outcome, called the dominant or hegemonic position, is when the interpretation of the message is made in the intended way by the reader or viewer. The person believes what they are told and does not question the validity of the statement. The second is called the oppositional, where the idea or message is opposed and rejected by the audience. The third negotiated position would be when the idea takes on localized characteristics or is becomes multifaceted as it splinters in its various meanings. The understanding of the message is not always the desired idea or an opposition to it, but rather can lead to a dual understanding of it. ${ }^{34}$

Hall's original theory was used to describe forms in media, specifically television and the method of interpreting events or arguments as they occur. I have therefore changed the variables slightly to suit this thesis, using the issuing of policy by means of the described speeches as the specific encoding event and the decoding levels the interpretations of both artists in the form and subject of paintings and critics assessing those paintings. The result is a viewing of how the policy was decoded by individual artists over the described periods and a method for gauging the effectiveness of policy in determining outcomes. It also provides an avenue to evaluate whether changes within

\footnotetext{
${ }^{32}$ Hall refers to the event as the "moment" thus highlighting its importance as a fixed event.

${ }^{33}$ Stuart Hall,"Encoding/decoding," in Culture, Media, Language, ed. S.Hall et al. (London: Hutchinson 1984), 135.

${ }^{34}$ Ibid., 136 .
} 
paintings were a result of the policy or another variable such as interactions amongst artists.

\section{Orientalism}

Orientalism as a term was used long before it was discussed by Edward Said, who redefined and expanded it into a theory in his seminal work Orientalism. Orientalism prior to Said's work was known among scholars of art history as a specific form of paintings undertaken primarily by French painters ${ }^{35}$ of the "Orient" or a place deemed as "exotic". The paintings depicted the "Orient" as a mixture of foreign animals, buildings, brightly dressed people and often women in limited attire or sensual portrayal. Said credits those early paintings as part of the inspiration for his study on the subject. ${ }^{36}$ Said's thesis was that the concepts of an Orient or East have been contrasted to the West throughout literature to prove the superiority of imperial power and western culture. The work Orientalism drew primarily upon literary examples, although Said referenced other forms of expression that have been utilized in subsequent studies that examine this issue.

For Said:

Orientalism was ultimately a political vision of reality whose structure promoted the differences between the familiar (Europe, the West, "us") and the strange (the Orient, The East, "them". This vision in a sense created and then served the two worlds thus conceived." Orientals lived in their world "we" lived in ours. ${ }^{37}$

The concept of us vs. them serves as a powerful unifying concept that allows the participants of a specific group to imagine the similarities connecting them by contrasting

\footnotetext{
${ }^{35}$ Similar observations have been made concerning Russian art and its depictions of Central Asia, especially with the artists such as Vladimir Vereshchagin. Although I would add that Vereshchagin's paintings, from the few that I have viewed in various galleries, lack the sensual undertones which Said has identified as being an integral part of the French works.

${ }^{36}$ Edward W. Said, Orientalism, (New York: Pantheon Books, 1978), 118-119.

${ }^{37}$ Ibid., 43-44.
} 
those traits against those of another perceived group. Said's idea was that a particular political dimension existed setting it apart from past ideas especially when coupled with the linkages to literary production. The result was a completely new lens for interpreting colonial actions, arguing that they reinforced and allowed for the power structures of dominance. Authors have since applied the theory as a way of examining other examples of colonialism that include studies of culture pertaining to the Tsarist and Soviet periods. These Eurasian studies have included discussions pertaining to Uzbekistan.

In her dissertation, scholar Laura Adams uses orientalism to explain how Uzbek culture was used by the Soviets as a selling approach inside and outside of the Soviet Union of an "exotic" cultural form. Adams also describes in detail how the contemporary Russian government skillfully cultivated the notion of the exotic previously used by the Soviets to advance their new agenda. Adams' research demonstrates that cultural elites ${ }^{38}$ have simply exchanged the name "socialist" with that of "nationalist". Adams" work is referenced in my study in examining the usage and utility of the "exotic" label by Uzbek artists as a means of self-empowerment and to thwart constant changing rules of censorship. Conversely, my own study also examines the way censors used the imaginings of the exotic to advance their own agenda of shaping what continues to be a form of cultural interference.

\footnotetext{
${ }^{38}$ Adams defines the term as including those who "a) received higher education in the arts (either in performance, administration, or criticism) or in cultural studies (such as folklore); and b) who are now or were during the Soviet period employed professionally in the arts or culture." in Adams, "Celebrating Independence." 8.
} 
Similarly, Anthony Shay explicitly cites Said in his evaluation of dance arguing that much of the genderization ${ }^{39}$ of dance within Uzbekistan, Egypt and Iran was the result of the European narrative of the exotic east. Soviet policy in Shay's account was a complete reorientation of dance to fit European standards creating western classical ballet styles, while making links to sports, martial arts and work. It emphasized the role of women in dance to fit European expectations for a sensual woman, while limiting men's roles as dancers based on different gender conceptions. Shay draws links between more traditional forms of dance involving males in Egypt, Syria and Uzbekistan and its challenge to European mores. Shay explains that the European interpretation of male dancers was to view their involvement as having homosexual undertones. Instructors in each respective country set out to feminize dance and bring it into line with European ideals, which included satisfying the need for the exotic through dress and dance movement. Shay's work will be used in my discussion of the Soviet evaluation of painters Usto Mumin, whose depiction of bachas caused considerable challenges for the Soviets. It is also used as a framing device to understand the gender dimensions and cotton picking within Uzbek paintings.

Orientalism's extensive use within the study of the period can be explained in part because the concepts of "us" and "them" mirrors the terms employed at the time by Soviet officials: "Russians" and "non-Russians." I also link to the Orientalist mindsets terms that include "backward" and "primitive" each serving as ways of reinforcing differences placing the Russian nationality at a higher cultural level. The term primitive can be used as an artistic style description, but when it is referenced in this study, was

\footnotetext{
${ }^{39}$ Shay uses the term is to describe the assignment of particular behaviors or characteristics to a specific gender. See Anthony Shay, "Choreographing Hyper masculinity in Egypt, Iran, and Uzbekistan," Dance Chronicle 31 no. 2, (2008): 211-238.
} 
always as a euphemism for being underdeveloped or backward often appearing alongside one of these words. It was regularly used by the Soviet artistic leadership to describe art (non-Russian) that they opposed, including miniature art works. Interestingly, the term "primitive," (primitivist) was also used by some Uzbek artists as a tool by appealing to imagined elements of their Republic.

The usage of the terms backward and primitive can be closely linked to the urgency for modernization in the region, as a key goal for the Soviet Union. The goal was to create a successful Soviet Republic, which would provide economic benefits to the Union. It justified Soviet interference in art forms ranging from paintings to theatre, but also extended well beyond cultural policy affecting technology, architecture, and everyday life. Artist's works in turn were used as a means to reinforce those changes through the use of Socialist Realism. The thesis will now begin with a discussion of miniature artworks in chapter one, followed by a chapter describing early $20^{\text {th }}$ century Uzbekistan. Then the subsequent chapters will discuss the 1930-1960s, followed by a brief conclusion and discussion. 


\section{Chapter Two: Outside Influence and Exchange in The Pre-Revolution Period}

The traders of the Silk Road changed the style of elite dress in Italy; someone buried Chinese pottery in 15th-century Swahili graves. I have heard it said that the bagpipes started out in Egypt and came to Scotland with the Roman infantry. None of this is modern,

- Kwame Anthony Appiah ${ }^{l}$

In order to understand the way Uzbekistan's culture was impacted during the Socialist Realist period, it is necessary to first examine how paintings were affected in the past. Although it is tempting to consider the notion of an authentic, untouched, uninfluenced culture, this chapter argues cultural appropriations occurred continually throughout the region and during the conquest by imperial Russia. An examination of the artworks that existed prior to 1865 will allow the reader to understand both the significance and differences in cultural influences that occurred in the early twentieth century and into the Socialist Realist period. During this chapter I will make direct connections between the art forms of the fourteenth to nineteenth century and the 19301960s works, on which this paper concentrates.

In Central Asia, cities situated on the Silk Road served as nexuses of cultural appropriations. Cultural exchanges shaped and developed paintings, in particular miniatures, drawing upon developments in the major city centres of Samarkand and Bukhara. Examining the pre-Soviet period presents greater understanding of artistic image construction throughout the region, which is needed to understand how the Soviets challenged or changed these previous works. In this study of miniatures I will directly

\footnotetext{
${ }^{1}$ Anthony Kwame Appiah, Cosmopolitanism: Ethics in a World of Strangers (New York: W.W. Norton, 2006), 4 .
} 
challenge the popular narrative put forward during the Soviet era that Russians and Soviet artists were solely responsible for introducing figures to the region. ${ }^{2}$ The notion that

Before the revolution imitative painting was practically unknown to the region because the Koran forbids to create images of living beings. For many centuries the artistic propensities of the people vent in different kinds of decorative applied and monumental arts...the European system of plastic arts, the arts...has therefore been unknown to the peoples of the Soviet East. ${ }^{3}$

In Central Asia two main painting forms existed prior to the tsarist conquest: gouaches and miniatures. Gouache works date to at least the twelfth century, while miniatures date to the fifteenth century and perhaps even earlier. The two works are drastically different. Gouache works appear on the exterior of buildings or else are placed as insets into walls. Gouache almost exclusively incorporated floral designs on buildings and were undertaken with a limited palette of three colours: green, blue and red. Miniatures in contrast measured approximately $14 \mathrm{~cm}$ in height and $11 \mathrm{~cm}$ in width, completed on paper often in books or scrolls, including a rich variety of colours featuring human figures and animals. The medium and subject matter of these forms will be examined further since they are the closest to the future canvas and paper works.

The exact origin of miniature art is unknown, although several authors have argued it developed from somewhere between Central Asia and China in the pre-Islamic period, and thereby reasonably developed as an art form incorporating a combination of several painting forms. Persia and China each influenced styles which featured specific representations of their subjects, most notably in depicting people in greater detail and

\footnotetext{
${ }^{2} U z S S R, 201$.

${ }^{3}$ Nigora Akhmedova, U. Tansykbaev : Selected works: Introductory section (Moscow, Sovetsky Khudozhnik Publications, 1989), n.p.
} 
unnaturally elongated. As Islam spread throughout the region, miniature art changed by incorporating full scenes of stories associated with the Koran. In later periods miniatures appeared in the Ottoman Empire (roughly fifteenth century), India and several small empires in the region.

The purpose of the miniatures were rather complex; Ismailova argues that painters tried to create an idea, rather than a "the concrete event". An example would be one miniature's depiction of a rather complex set of events involving the defeat of Sultan Jalal Ad-Din by Chinghiz Khan, where the picture not only depicts the defeat, but also the pursuit and capture of the Sultan. "It is a simple yet elegant interpreted composition of a legendary subject," explains Ismailova. ${ }^{5}$ Meanwhile Robinson argues "they are pictures with a story," ${ }^{, 6}$ - which is another way of describing the lack of a clear time and place for a specific event. This is important to note because many of the later twentieth century paintings influenced by miniatures also incorporated story elements. These influences set apart Uzbek artists from their Russian and Soviet contemporaries who all placed emphasis on specific events rather than a non-linear story.

It is my opinion based on authors' writings $^{7}$ that the best definition of a miniature would be: a small two dimensional painting, which contains a story that is not necessarily based on a specific historical moment or event. However, the miniatures incorporate

\footnotetext{
${ }^{4}$ E.M. Ismailova, Oriental Miniatures of Abu Raihon (Beruni Institute, Tashkent 1980), 15. ${ }^{5}$ Ibid., 23.

${ }^{6}$ B. W. (Basil William) Robinson, Persian Drawings from the 14th through the 19th Century (New York: Shorewood Publishers, 1965), 13.

7 Five commentaries, written by Robinson, William Lilly, F.R.Martin, Pygrachenhova and Ismailova were examined. Each provided an evaluation of Central Asian miniatures on the question of: "What do they represent?" The common elements identified included stories with links to religion and mythology rather than identifiable places or a people.
} 
elements of a recognizable time and place such as clothing or buildings. ${ }^{8}$ This incorporation of local elements explains why a Central Asian miniature can be distinguished from an Ottoman or Persian miniature - since the dress and buildings were different between regions - and thereby confirms the presence of a pre-Russian-Soviet, regional art style developed in Central Asia with specific identifying features of Uzbek artists.

Prior to the sixteenth century, miniature art had developed into eight basic styles with several variations within those styles. ${ }^{9}$ The paintings were rarely signed - an element which seems to have continued into the paintings by some later Uzbek painters. If they were signed, as a rule they were also dated and placed on the last sheet of the complete manuscript. ${ }^{10}$ The miniatures themselves were always done in specific placement on the page often with calligraphy on the bottom or in the top corner of the page to assist the reader in identifying the specific work. Later in the paper, we shall see this element carried into paintings with signatures and dates both lacking.

Asian-based miniatures of this period tended to be more time-consuming to produce and significantly more expensive than European manuscripts, because printing presses were forbidden by governing or religious leaders in these locales (which meant each had to be done exclusively by hand). ${ }^{11}$ Therefore, Asian miniature art was produced in limited numbers, similar to the early medieval folios of Europe. The cost of production and materials also meant patronage needed to come from the wealthier of society, and the

\footnotetext{
${ }^{8}$ G.A. Pygrachenhova i Zi Raximova, Sredneaziatskie Miniatiura, Tashkent: Glanaia redktsiia zhtsiklopedii, Gafura Guliamaiiu, 1987. 9. (hereafter cited as $S M$ ).

${ }^{9}$ Ibid.,6.

${ }^{10}$ Ibid. 6.

${ }^{11} \mathrm{~F} . \mathrm{R}$ (Fredrik Robert) Martin, The Miniature Painting and Painters of Persia, India and Turkey from the 8th to the 18th Century (New Delhi: B. R. Publishing, 1985-1912), 36.
} 
product was not affordable to the general public. For example, in the Ottoman Empire, the grand Vazir Muhammad Pasha (seventeenth century) gave an artist 1,000 gold pieces as a "gratuity," 12 while as late as the nineteenth century Central Asian miniature artists could still sell their works in book form for more than 10,000 pounds of wheat. ${ }^{13}$ Local rulers, due to the costs, often constructed specialized workshops with masters training the students in an apprentice-type fashion. ${ }^{14}$ Consequently, due to this highly integrated practice, miniature art was virtually inaccessible outside of higher-ranking members of the Uzbek courts and cultural producers.

In terms of execution, miniatures differ in their early appearance from European art, which include three dimensions as opposed to the two dimensions found in miniature art. Poliakova explains using the example of the depiction of a pond: "European art would represent the pond with a trapezoid or oval, while a miniaturist would depict it as square or round." 15 The artist's interpretation resulted in a completely different looking pond, although both would be recognized as such by their respective cultures. Miniatures also differ significantly from European art in their earlier forms (pre-nineteenth century) by rarely using techniques of light and shade, but rather flat representation.

The area now called Uzbekistan was considered an important centre for the creation of miniatures, where two distinct schools emerged in the region from the fourteenth to sixteenth centuries, paralleling changes in Persia. In 1336, as Amir Temur ruled Samarkand, various art forms flourished, including an entirely new form in

\footnotetext{
${ }^{12}$ Martin, The Miniature Painting and Painters of Persia, India and Turkey, 107.

${ }^{13}$ Edward A. Allworth, Central Asia, 130 years of Russian dominance: A historical overview, (Durham NC: Duke University Press, 1994), 524.

${ }^{14}$ Ibid., 36-39.

${ }^{15} \mathrm{SM}, 8$.
} 
miniatures now called the Timurand or Timurid School. The miniatures in this style combined further use of colour and were more detailed than in the past. They also contained Chinese influence and a "pre Mongol" patterning influence seen in the miniatures from the "Baghdad school,"16 as William Lillys describes it.

In the earlier period there is considerable evidence of influence from China, with painters from the region sent to visit China's imperial court. ${ }^{17}$ The result of those exchanges can be found in a catalogue of a 1930s exhibition in London, UK, describing a miniature volume from the Fifteenth Century that was on display. ${ }^{18}$ The volume literally charts a progression containing Chinese works, "a number of hybrid works, half Persian and half Chinese," along with examples from the "borderlands of Central Asia."19

European influence can be noted as taking place even during this early period. Williams, a researcher of primarily Persian miniatures, has hypothesized that as early as 1403 - when Gonzalez de Clavijo, a Spanish Ambassador, visited Samarkand - he may have left images which served as inspiration for a depiction in a miniature produced shortly afterwards, that of a dragon battling Sikandar (Alexander the Great). ${ }^{20}$ More concretely, during the Fifteenth Century Italian painting styles were noted as having influenced some of the designs in Samarkand miniatures, as well as the subject matter. ${ }^{21}$ The reverse of cultural influence on European works likely also occurred, but that point exceeds the limits of this thesis.

\footnotetext{
${ }^{16}$ Refers to a style of painting from the area around Baghdad in the $13^{\text {th }}$ century, which, according to Williams incorporated very bright colouring with complex patterning.

${ }^{17}$ Laurence Binyon, Basil Gray, and J. V. S Wilkinson, Persian miniature painting, including a critical and descriptive catalogue of the miniatures exhibited at Burlington House, January-March, 1931. (New York: Dover Publications, 1971), 57.

${ }^{18}$ Ibid.

${ }^{19}$ Ibid.

${ }^{20}$ William Lillys, Robert Reiff, and Emel Esin. Oriental Miniatures; Persian, Indian, Turkish. (Rutland, Vt:C.E. Tuttle Co., 1965), 54.

${ }^{21}$ Ibid., 31 .
} 
In the city of Bukhara, another school formed some 100 years later in the Sixteenth Century. Elena Poliakova argues that the figures begin to be larger, more rounded and heavier in comparison to the previous forms which were elongated. ${ }^{22}$ Specifically, Poliakova notes that figures come to have narrowed slanting eyes with the mouth moving closer to the nose. These miniatures also allowed for a three-dimensional element, a significant change as discussed earlier since most miniatures do not have this facet. Finally, colours become bright, illustrating changes in Central Asian court clothing of the time. These associations of bright colours become important since they continue to serve as a lens for viewing artworks during the period of socialist realism.

\section{Nineteenth to Early Twentieth Century Influences}

Despite these two important schools, the number of Central Asian miniatures was still small in comparison to the number produced in Persia. Their appearances were also more susceptible to changes due to their proximity to Tsarist Russia. In the Eighteenth and Nineteenth Century miniature art began to show signs of change and representations of everyday life began appearing. ${ }^{23}$ The everyday paintings included vignettes of people engaging in trade or street scenes. Although none of the authors offer explanations as to why this change occurred I believe it could be related to European influence. This is based on the fact that the structure, composition and backgrounds all began to change in miniature pieces as well. Similar changes occurred in the same period in Persia and the Ottoman Empire as European influences on miniatures began to occur in no small part due to increased interactions along the Silk Road.

\footnotetext{
${ }^{22}$ Ibid., 58.

${ }^{23}$ E.M. Ismailova, Oriental Miniatures of Abu Raihon, 17.
} 
Miniature art in the contemporary Uzbek area were a part of these changes, particularly regarding the subjects of their paintings. One large plaster panel (Fig 1) I observed in Tashkent's Fine Arts Museum - dated the late nineteenth century to early twentieth century - included figures instead of the previously mentioned formal designs. In this panel, two figures (and possibly a third) are shown watching boats on a bridge near a building which appears to be a mosque. Interestingly, one of the boats included in the panel is a steamboat, with a smoke stack clearly visible. The undamaged parts of the figures are simplified in their features and incorporate limited facial features or detail and are similar in many ways to the miniatures of the late nineteenth and early twentieth centuries. There is almost certainly influence stemming from China in the depictions of the people standing on bridges, a common theme in Chinese paintings also performed on large scales. Moreover, the panel also incorporates European influence specifically its focus on an everyday event similar to the miniature artworks of the past century. The panel most importantly incorporates a European perspective with its positioning of boats in the background and foreground. The result is a true hybrid between European, Chinese and miniature works on a large scale, with in my own opinion an emphasis on the European.

In his examination of architecture in Central Asia, Allworth explains that during later modernization campaigns of buildings in Central Asia (1940s), under the influence of Socialist Realism, buildings were plastered and then "superficial outlines of the art of the miniatures" were placed on them. ${ }^{24}$ The early twentieth century panel observed in Tashkent was almost certainly an early example of one of those plastering attempts. The result, as Allworth argues, and I agree, was a complete reversal of the intention of the

\footnotetext{
${ }^{24}$ Allworth, Central Asia, 130 years of Russian dominance, 525.
} 
miniature, which were meant to be small. By placing them on buildings and within the interiors, the Russians were allowing for the consumption of the miniature in a mass form. This meant reorientation of the works from an individual observation into a mass spectacle. It provides an early example of the how the Central Asian art discussed in this chapter would be re-imagined in later periods.

The influences and exchanges prior to Tsarist control of Tashkent provide a framework with which to evaluate some of the future influences and changes. Central Asian miniature art underwent significant changes whether from European, Persian or other's influence, as it incorporated elements from other art works. The influence was not directed, but carefully reflected, gradual, and continual changes in contrast to the Socialist Realist period.

However, this chapter's observations have most importantly established that a form of figure painting did exist in the area prior to direct Tsarist or Soviet influences. Although this is not surprising, it definitively contradicts the later Soviet claims of the absence of figures in Central Asian art. The miniatures were, given the expenses, relegated to only the select few, which meant the populace would not have had access to them - allowing the Soviets to argue that their paintings were the first of their kind. As I will discuss in the subsequent section, the Russian conquest of Turkestan and the occupation of Tashkent brought with it several changes: mainly the introduction of easels, new paints and European instruction. I will also discuss in the following chapters how the Russians and then Soviets completely changed the cultural value of these past works (miniatures) as decorative art forms by defining them as folk art, while "real" art was to be displayed and viewed by the masses. 


\section{Developments in the Late Tsarist Period}

Artworks by the late nineteenth century were rapidly changing in the area now called Turkestan predominately under Russian control following the 1960s conquest of the region. The influences from Russia ranged from the artistic styles to new art supplies and materials, and particularly in art school instruction. The intention and influence was relentless from the late 1880 s to the changes that continued into the $1930 \mathrm{~s}$.

The increased European influence in the 1880s meant artwork for the first time began to be completed on easels, differing from miniatures which had always been done on flat work spaces. A shift in the kinds of paints and other materials occurred at this time: oil paints, watercolours, and canvases were introduced, although not entirely uniformly throughout Central Asia. In the Karakalpakstan region of Uzbekistan, canvases were not common until the $1960 \mathrm{~s}^{25}$ suggesting that the shift away from more traditional forms of art was gradual and highly dependent upon locale. It may also serve to explain why most of the artists in the 1920-1960s tended to congregate in one of two cities: Tashkent and Samarkand. These centers would have provided greater access to art supplies, which had proven to be a problem even as late as the 1920s with major educational institutions in the region, such as the Kazan school (located in the city of Kazan in contemporary Tatarstan), experiencing low supplies for their students. ${ }^{26}$

The end of the nineteenth and early twentieth century saw Central Asian urban residents painting scenes of mountains, still life, and for the first time people in a nonminiature method and style. State secondary schools were founded by the imperial

\footnotetext{
${ }^{25}$ This assertion is made by the Nukus Art Gallery on visitor display boards in the gallery on the history of art in the Karakalpakstan region.

${ }^{26}$ Soyuz Khudozhnikov Uzbekistana, P.P Benkov 1879-1949 Vospominaniia Perepiska (Gafura Guliama, 1981), 42 (hereafter cited as P.P. Benkov 1879-1949 VP).
} 
regime in 1890s Tashkent with instructors coming from Saint Petersburg and Moscow. The instructors taught Russian and European styles of painting and drawing, often having students copy works from European and Russian masters of the past century. ${ }^{27}$

Nevertheless, a substantial separation existed between the local population and the Russian one, with "most" of the students coming from rich and wealthy Russian families. $^{28}$

These new instructors brought with them ideas from the Avant Garde movements - including cubism, impressionism, and other forms underway in those major cities. The result was a range of painting and teaching styles. Nickolai Karahan, a future influential painter in the Republic, observed in 1923 that at least five teaching methods were being undertaken at the Tashkent Art College alone. ${ }^{29}$ According to Karahan, the techniques ranged from decorative art or "fairy tale world" art to methods influenced by Matisse and Picasso serving as one of the few examples that a true range in painting and painting techniques existed in the period. ${ }^{30}$ Unfortunately, Karahan does not give any suggestions as to the ethnic composition of the classroom, but it is safe to assume given the time period the majority were Russian. This inflow of artists from across the Tsarist Empire and their accompanying styles would continue until the advent of socialist realism, when the artists and the reasoning for coming to Uzbekistan changed.

Miniature art had significantly diminished due to a gradual decline through the late ninetieth and early twentieth century, due to diminished patronage and value. ${ }^{31}$ Local

\footnotetext{
${ }^{27}$ Khakimov, Art Education in Uzbekistan, 182.

${ }^{28}$ Ibid., 181.

${ }^{29}$ Mastera iskusstv Uzbekistana Karakhan (Tashkent: Izdatel'stvo literaturyi iskusstva imeni gafurliiama 1978), 7 (hereafter cited as MIUz).

${ }^{30}$ Ibid.

${ }^{31}$ Allworth, Central Asia and 130 years of Russian Dominance, 524. and E.M. Ismailova, Oriental Miniatures of Abu Raihon, 16.
} 
financial constraints were severely impacting the region at the time. Nevertheless, miniaturists still continued miniatures as an art form into the early 1920 s, with older painters continuing the technique, but without younger apprentices to carry on the traditions. The new art styles, techniques, and depictions, being encouraged by Russians visiting and residing in the region, were attracting younger people - many of whom received financial backing from their families. The change in style may have been directly linked to finances, since a change in style could potentially result in furthered status or prestige. The miniature techniques during the period also underwent changes besides the previously-described movement toward wall paintings. They were also being rendered in a changed format and onto canvas.

Roughly forty years prior to Karahan's aforementioned descriptions of the fairy tale drawings (1874), lithograph printing was introduced into the region via Persia by Seyyid Muhammad Rahim II of the Khanate of Khiva ${ }^{32}$ (located in current Uzbekistan's south west). Until this time, according to Allworth's account, the Southern Central Asian region had no lithographic or printing facilities. ${ }^{33}$ Thus, even within the Tsarist period, the influences to Uzbek art were not exclusively Russian. The most important impact was not necessarily the images that were produced, but the speed with which they could be produced and the utilization of printing within books. Similar to Turkey - which had seen the introduction of its printing press in $1727^{34}$ - it added to the decline of the time and labour-intensive miniature art form. It also allowed for a future avenue of expression for Uzbek art to unfold, which became essential during the period from 1930-1960.

\footnotetext{
${ }^{32}$ Allworth. The Modern Uzbeks, 117.

33 Ibid.

${ }^{34}$ Lillys, Reiff, and Esin, Oriental Miniatures; Persian, Indian, Turkish, 77.
} 


\section{Chapter Three: Early Russian Revolution Period}

During the lead up to the Russian Revolution, as previously mentioned, artistic styles had begun to expand in range and variations. By 1917, avant-garde movement had blossomed, even trying to assert dominance in the art world following the Revolution. ${ }^{1}$ In response, a counter movement emerged, drawing upon nineteenth century realist ideas: this group has since been referred to as Socialist Realist. ${ }^{2}$ Lenin in 1919 sided with the socialist realists, "characterizing them [the Avant-gardes] as the revolt of the "insanely overfed" bourgeois intelligentsia." State support would officially flow to the Socialist Realist painters, although the avant-garde movement was far from being defeated, with artists still arguing for their particular works until the creation of the Union of Artists in 1932 and conceding after the state's official adoption of socialist realism in 1934.

These struggles among artistic styles for dominance were occurring as Tashkent's status turned "mythical" during the late Tsarist period. ${ }^{4}$ The city's population, unlike its peers, grew during the Russian civil war with refugees arriving from famine hit areas of the Volga region. ${ }^{5}$ Artists, who were either expelled or faced expulsion in Moscow or other areas during the period, looked to the Uzbek city as a sanctuary. Its distance and potential promise (especially among the avant-garde artists) led to a mass influx of painters from other areas during the early post-revolution years between19191925. The result was that the arriving painters, many of whom would also be instructors at higher learning, successfully established three major artistic styles realism, avantgarde, and a hybrid between indigenous forms and modern styles.

\footnotetext{
${ }^{1}$ Bulanova and Rosenfield, Soviet Disunion, 12.

${ }^{2}$ Ibid., 13.

${ }^{3}$ Ibid.

${ }^{4}$ Sahadeo, Russian Colonial Society in Tashkent, 224.

${ }^{5}$ Ibid., 224-225.
} 


\section{Three Artists, Three Styles}

Pavel Benkov, a realist painter, provides an example of one artistic path chosen by émigrés arriving in Central Asia. Benkov created realist works based on European training methods and served as a source of Russian and European influence. His involvement in key events throughout this thesis warrants a discussion of his background and reasons for coming to Uzbekistan. Benkov, like other painters at the time, wanted to escape the artistic disputes underway in Russia concerning what form art should take in the new Union. Turkestan (Uzbekistan) offered a distance from tensions in the postrevolution art world, allowing those artists who arrived in the country to continue exploring their artistic expressions with limited criticism. Benkov's own style was more conservative and realist based, having been schooled in Russian classical art work during his five years at the St. Petersburg Academy of Arts (1901). He had studied under D. N. Kardovskii, a realist painter famous for his historically themed canvas. His time with Kardovskii is cited as having the greatest influence on his work. ${ }^{6}$

Benkov would later go to Kazan, and eventually began teaching in $1909 . \mathrm{He}$ presented a different teaching style, encouraging his students to generate their own ideas and unique works. His students, later recalling his teaching abilities, spoke of his genuine interest in the encouragement of art. One typical story of the period spoke of Benkov's input and advice to a student during nights after the student was finished his work at the local municipal government. ${ }^{7}$ The teaching style and his enthusiasm for developing and

\footnotetext{
${ }^{6}$ Soyuz Khudozhnikov SSR, Ministerstvo Kultury Uzbekskoi SSR, P.P. Benkov 1879-1949, Katalog, Moscow: Soyuz khudozhnikov uzbekskoi SSR tsentralnyi dom Rabotnikov Iskusstv, 1961, n.p. (hereafter P.P Benkov 1879-1949 catalog)

${ }^{7}$ P.P. Benkov 1879-1949 VP,189.
} 
encouraging discussion about art is important to note because it is the opposite of teaching approaches taken later during the Socialist Realism period.

Benkov's teaching style also contrasts to earlier periods of art instruction given by past Russian art teachers, who discouraged students from exploring and discussing new approaches and techniques. This openness and innovation also put him at odds with teachers at the Kazan school, where he had previously taught. Although Benkov objected to the "formalist" art his colleagues taught he was angered by a threat to close down the Kazan school and exclude students if teachers did not align with the newer teaching style, even writing a letter in protest to the threats. ${ }^{8}$ He left for Samarkand shortly after the dispute, but not before being recognized as a National Artist of Tatarstan. Benkov is a representative of one of the "schools" of art founded at the turn of the century in Uzbekistan. Arriving in Uzbekistan after the Russian revolution in 1924, he later helped in the establishment of a highly influential art school in Samarkand, which eventually became Samarkand Art College - influencing several generations of Uzbek artists and leaving his mark of realism on the Republic.

The school, according to one student, produced more than just a group of artists; it produced a group of professionals who would commit their lives to the arts. ${ }^{9}$ Many of the instructors, including Benkov, were closely linked through study and previous instructions at other schools in the region - in particular the Kazan school, a relatively new learning institution founded in 1895 under the direction of the Imperial Academy of Arts. The Kazan school's connection to the academy and its difficult selection process gave it a certain prestige, explaining why many of the future instructors could be linked

\footnotetext{
${ }^{8}$ Ibid., 42-43.

${ }^{9}$ Ibid., 185.
} 
to the school. Originally, its connections to the Imperial Academy would result in an emphasis on classical works. However, shortly after its opening it underwent similar experiences as peers in Moscow or Leningrad, producing a range of avant-garde or realist students.

Besides the realist painters epitomized by Benkov, avant-garde artists exemplified by Mikhail Kourzin also arrived in the Republic. Kourzin makes for an interesting case mainly because of his international travels. Kourzin, originally from Barnaul (Southern Russia), like Benkov also attended the Kazan school (1908), but emerged with a different teaching and painting style. Upon graduation, he left for the Moscow School of Painting, Sculpture and Architecture to continue his studies. He spent time learning in private studios in Moscow, before going to Tashkent along with a number of artists in 1919 - each identifying with a form or expression of the avant-garde. After a little more than a year he travelled to Moscow, teaching at the prestigious VHUTEIN ${ }^{10}$ school for a time before once more returning to Uzbekistan in 1924. At this point he stayed for a longer period, working as an instructor in Samarkand and within a number of fields ranging from newspaper printing to theatre.

Kourzin's famous works contained imagery with references to social inequalities in capitalist society, as in the painting Capital -presently believed to have been completed sometime around the early 1930s. This painting stood out among the pieces which I was able to observe at the Nukus museum, since it obviously did reflect the usual subject matter of other paintings from the same period. What differentiates Kourzin and

\footnotetext{
${ }^{10}$ The VHUTEIN was a major higher technical art institute in Moscow, with affiliated locations in St.Petersburg/ Leningrad. Its students and instructors included many of the major Russian avant-garde painters.
} 
the group of avant-gardes he represented was that they continued painting in styles begun in other locations.

Alexsandr V.Nikolayev provides a third example of the direction artists took during the period, mainly blending indigenous concepts with European works.

Nikolayev's studies began in the Russian-based Sumsk military school in the early 1900s, but it was his attendance at the Second State Free Art studio in Moscow, where he studied under the famous painter Kazimir Severinovich Malevich, that most influenced him. He maintained a friendship with Malevich, who would become a heavily-censored painter by the Soviets, until the latter's death in 1935. Nikolayev's own studies were put on hold during the revolution. After the partitioning of the region into Republics he was sent as part of a group to study the Central Asia region and produce ethnographical works.

In recalling his arrival to Samarkand Nikolayev would state:

My arrival in Samarkand was a decisive factor in my creative work for some years. I was struck by the fantastic nature of the East which charmed with the unusualness of its tenor of life and decorative art ${ }^{11}$

Although Nikolayev's emphasis on decorative art was likely connected with a romanticism for the region, his complete change in behavior suggests a much more profound personal impact. He changed his name to Usto Mumin, meaning "resigned master" in Uzbek, converted to Islam and even learned the Uzbek language. His decision contrasted with many teachers at the time, such as Benkov, who taught classes in Russian, while his actions set him apart from the avant-gardist painters.

${ }^{11}$ R.V. Eremeh et al., A.V. Nikolayev (Tashkent: Garfur Gulyam, Fiction and Art Publishing House, 1982), 27. 
Unquestionably, Nikolayev's life brings to mind the same life decisions that the famous French Post-impressionist painter Paul Gauguin undertook. Gauguin lived in Tahiti for a number of years with the local Tahitian population, partaking in activities helping to repel European advance. The parallels are not coincidental. In a letter penned in his early years Nikolayev explained that he had hoped to duplicate Gauguin's experiences in Tahiti by immersing himself in Uzbek culture. ${ }^{12}$ This makes Nikolayev perhaps one of the most interesting cases at the time in how influences of culture and policies impacted an artist.

Even prior to the official changing of his name, Nikolayev worked under the pen name Muninbek, likely as a way of eluding possible criticism since expectations at the time were for Europeans in the region to produce realist styled paintings. His appreciation of art must have been obvious in his early years. V.L. Vyatkin, a famous archeologist active in Samarkand at the time, sensing "a true connoisseur of art," decided to give Nikolayev miniature manuscripts from Persia and Central Asia. ${ }^{13}$ This is likely one of the major avenues for his miniature inspiration, as Nikolayev set out copying the works, eventually graduating to creating his own two-dimensional variations melded with European styles.

The works attracted considerable criticism even during the early period and eventually led to his imprisonment (1935), shortly after the beginning of Socialist Realism (1934), a point to be discussed further in the proceeding chapters. Nonetheless, like other artists he still participated in the promotion of the Soviet State. Throughout his early years in the country, he created "propaganda and education posters," which

\footnotetext{
${ }^{12}$ The Desert of Forbidden Art, DVD, Pope Amanda \& Geogiev Tchavdar. 2010, (USA: Desert of Forbidden Art LLC). (hereafter cited as The Desert of Forbidden Art).

${ }^{13}$ Eremeh, et al. A.V. Nikolayev, 30.
} 
idealized and provided a reinforcement of many Soviet signs of progress, notably cotton picking. ${ }^{14} \mathrm{He}$ also created illustrations for books critical of past governments in the region suggesting that he understood that an artist's experimentations needed to be tempered by the pragmatic need to receive state financing.

Similar to Usto Mumin's work artist Tatevosyan Organes Karapetovich's early painting is known to be influenced by miniatures, exemplified in his work Village (Fig.2), done in 1919. The spatial placements in Village, the rendering of the figure and the perfect symmetry are both hallmarks of miniatures. The animals in the top left corner of the canvas are also perfect representations of earlier miniatures.

Tatevosyan and Usto Mumin's works were in many ways similar to the intent of the miniature style that I observed on the earlier described wall panel in Tashkent's Fine Art Museum, mainly a change in size and medium. By expanding and resizing the pieces, the artists were once more changing the personalized elements that had been originally intended within the genre. Size, as the namesake of the miniature painting form suggests, was principally important, but as previously established was not the only defining element of the painting style. Tatevosyan and Usto Mumin's works still maintained connections to miniature works by following the tenants of placement and story. Their own insertion of other European elements suggests a blending of traditional Central Asian works with new outside influences. The art now created by these painters in Uzbekistan was meant to be viewed and convey messages to everyone, for everyone. Past miniatures were created as private and with a not-so-subtle message of recognizing the owner for his wealth and prestige. Hence, this was moving the miniature artworks into more European standards of ownership, where mass viewing of art in galleries or on

${ }^{14}$ Eremeh, et al. A.V. Nikolayev, 35. 
walls was the intent. At the same, this movement away from recognizing the owner aligned with some of the socialist goals of creating works for mass consumption.

\section{Artist Associations}

The artists who belonged to the realists and the avant-garde movements were usually affiliated with large artist organizations, which had local chapters in major Uzbek cities. The affiliation with groups was vital since, as previously discussed; even learning institutions faced challenges in acquiring supplies. One such organization which represented the realist style was the Association of Artists of Revolutionary Russia (AARR), a state-supported group that had chapters across Russia and in Uzbekistan, with its major centres located in Moscow and Petrograd.

The Association's stated declaration was:

to accurately portray for humanity the greatest moment in history in its revolutionary upsurge. We will document the present: the everyday life of the Red Army, of the workers, peasants, revolutionaries and heroes of the labor front. We will show the true picture of reality, not some abstract notions that discredit our Revolution in the eyes of the world proletariat ${ }^{15}$.

In many ways, members of the Association of Artists of Revolutionary Russia were the precursors to the socialist realism ideal, since they aimed at constructing a reality which was the reflection of workers and incorporated heroes of labour into the works. The last statement concerning the rejection of abstract notions was clearly aimed at contrasting and distancing itself from the avant-garde movement. The result was that many of the scenes completed in the period incorporated scenes of workers often building or creating. In the case of Uzbekistan this meant depictions of workers preparing to farm or dig canals, while at the same time displaying images of market places and debilitated buildings.

\footnotetext{
${ }^{15}$ Bulanova and Rosenfield, Soviet Disunion, 14.
} 
Benkov was the unofficial head of the group's vanguard in the region (joining it early in 1922) and participated in exhibits which were organized to showcase the realist styles. One such exhibit was organized in 1928 in Tashkent, showcasing 16 artists and 261 works from Tashkent, all of whom belonged to a local branch of Association of Artists of Revolutionary Russia. ${ }^{16}$ Artist groups during the period were important in providing artists with the opportunity to display work. Nationality was not a basis for membership within the Association of Artists of Revolutionary Russia, unlike other creative organizations such as the Red Spark in Kyrgyzstan open exclusively to Kyrgyz writers. This meant that despite the name of Revolutionary Russia, Uzbek painters were permitted to join the group. This lack of separation explains in part the close association amongst the painter community since ethnic background did not pose an issue.

Another major association active in the period was the "Masters of the New East," also based in Tashkent. It included prominent painters such as Usto Mumin. The group's participants were still permitted membership in the Association of Artists of Revolutionary Russia branch despite the clearly marked differences between painters. The "Masters of the New East" were full of artists whose works were "abstract notions" as the official Association of Artists of Revolutionary Russia declaration would define them. An article about Masters of the New East appearing in the contemporary magazine San'at (The Uzbek word for art) states that it enabled "creative dialogue and relevance of exhibition activity." ${ }^{, 17}$ Certainly, we know from Benkov's experience in Kazan the reason some painters were leaving their previous locales in favour of

\footnotetext{
${ }^{16}$ Iskusstvo Sovetskogo Uzbekistana (Tashkent: Nauchno-issledovatelskii institut iskusstvoznaniia UzSSR, 1957), 71. (hereafter cited as ISUz).

17 "Masters of New East" in Global Artistic Process," Accessed August 12, 2010, http://www.sanat.orexca.com/eng/3-4-05/master.shtml.
} 
Uzbekistan was to avoid the conflict between avant-garde and realist groups. I believe if the painters had started to argue amongst themselves, they would have generated much of the conflict they had sought to avoid.

\section{Depictions}

Despite the differences that existed between artists in the 1920s and 1930s nearly all painters living in Uzbekistan regardless of style or nationality undertook studies of certain subjects, usually corresponding to imagery associated with the region and often supporting the state. For example, tea houses were depicted in paintings heavily from 1920-1930. Paul Stronski has argued Uzbek tea houses were important social spaces to the Soviets, with some establishments regarded as being part of the so-called "proper" Soviet culture. ${ }^{18}$ Soviet officials initially viewed teahouses as ideal social locations which could serve as meeting places for discussions of Soviet ideology. ${ }^{19}$ This explains why the paintings that depicted them were never subject to criticism. In fact, the paintings of teahouses enjoyed widespread official and international praise. Volkov's The Red Teahouse (1924) won the main prize at a Paris exhibition, while the lesser-known artist Bahrom Hamdami's Red Teahouse (1937) was regarded as "among the finest achievements of Uzbekistan painting. ${ }^{, 20}$ The works satisfied many of the stereotypes of the exotic and reinforced the two world's concept, allowing the viewer to enter the "East" world.

\footnotetext{
${ }^{18}$ Stronski, Tashkent: Forging A Soviet City, 64.

${ }^{19} \mathrm{Tbid}, .64$.

${ }^{20}$ Nigora Kultasheva. "The Art of Bahrom Hamdami." Accessed August 12, 2010. http://www.sanat.orexca.com/eng/3-09/nigora_kultasheva.shtml.
} 
However, this praise changed and Uzbeks were instead criticized for spending too much time drinking tea. ${ }^{21}$ The Uzbek image was compared to the idealized Russian who was hard working. ${ }^{22}$ In fact in 1937, the same year Bahrom Hamdami painted his fine achievement of Uzbek painting, "Russian delegates" at the Architects Union linked teahouse establishments to brothels. ${ }^{23}$

The tea house paintings served the dual purpose of reinforcing the stereotypes that had been ascribed to the region, while showing progress had been made with the use of symbols of the revolution. The works intersected between the need to view imaginings of Uzbek culture and in a contradictory fashion the desire to create the idealized space for the new citizen. Given this the Soviet conclusions of an idle work force in contrast to the hard working Russians were hardly surprising. As Said notes by placing separations in this case the stereotype as the starting points of policy "the result is usually to polarize the distinction- the Oriental becomes more Oriental and the Westerner more Western- and limit the human encounter between different cultures, traditions, and societies." 24 Consequently, even if the teahouses had succeeded in creating this idealized space the painter would have still needed to draw upon stereotypes.

One painting completed by Kourzin that I observed in Nukus, for example, depicts a number of Uzbeks sitting and drinking tea looking to be talking, others are lounging looking to be asleep, while a prominent painting of Lenin is situated in the top center of the canvas. An observer of the painting would conclude that the building was a place of relaxation and rest, but where serious political matters could be discussed as

\footnotetext{
${ }^{21}$ Stronski, Tashkent: Forging A Soviet City, 64.

${ }^{22}$ Ibid.

${ }^{23} \mathrm{Ibid}$.

${ }^{24}$ Said, Orientalism, 44-45.
} 
one's gaze is constantly redirected to Lenin by the tea house's support beams. The painting displayed visually the Soviet hope for its Uzbek citizens, who would gradually absorb socialist ideas and casually discuss issues of the day. However, these aspirations could never materialize because as the sleeping individuals showcased Uzbeks spending too much time in the establishments. The gradual discontinuation of teahouses in paintings paralleled many of the negative associations of the tea houses. By the late 1930 s, none of the major painters I examined were depicting teahouses.

This chapter has discussed painters prior to the advent of socialist realism and argues that a diverse range in styles and subjects existed within Uzbekistan. However, artists within Uzbekistan were not merely the receivers of influence; rather the reverse seems to have occurred with painters such as Usto Mumin who was personally affected by the art of the region. The result was a flourishing of styles and without any particularly sanctioned method. The interactions among the artists and painters associations in fact demonstrate that the painters were open to experimentations and individual interpretations. This would change radically in the 1930s when art shifted into an atmosphere of control not only for the artists, but for the students of the painters as well. 


\section{Chapter Four: The Socialist Realism Revolution 1930-1935}

Jack Chen, a British student, arrived in Moscow in the autumn of 1927 to take up studies in art and discover the differences between and the Soviet Union and Great Britain. The young student visited a number of art schools in the city, noting, similar to Nickolai Karahan's 1923 comment on Samarkand art, that instruction was not uniform in the era before socialist realism. ${ }^{1}$ Chen reported that in regard to teaching, "the methods of approach [are] not the same in all institutions. It depends on the teachers, the traditions of

the school. ${ }^{2}$ He also reported that art was being contested within academic circles, especially between painters in Moscow and Leningrad. ${ }^{3}$ The comments reinforce the idea that this disagreement between artists was not limited to Uzbekistan, but unlike in Russia the differences in approaches were less heatedly contested as demonstrated by the Kazan school and the exodus of painters from these areas.

The 1930s was a turning point for painting across the Soviet Union, reaching to the Uzbek SSR. ${ }^{4}$ The Soviets created major cultural changes within this decade that would recast not only painting, but culture as a whole in the USSR. The decade began with many of the same challenges that faced artists in the $1920 \mathrm{~s}^{5}$ The Communist Party may have officially supported the realist method for artists to follow, but associations and their affiliated artists could still continue to follow their particular vision of art. $^{6}$

Organizations like the Association of Artists of Revolutionary Russia may have had more

\footnotetext{
${ }^{1}$ Jack Chen, Soviet Art and Artists (London: Pilot Publishing, 1944$), 17$.

${ }^{2}$ Ibid.

${ }^{3}$ Ibid.

${ }^{4}$ Paul Sjeklocha, and Igor Mead, ,Unofficial art in the Soviet Union, (Berkeley: University of California,1967), 40; Bulanova and Rosenfield Soviet Disunion,12.

${ }^{5}$ Bulanova and Rosenfield. Soviet Disunion, 12.

${ }^{6}$ Ibid.
} 
influence than others in Central Asia, but as the previous chapter has established their ranks were packed with painters, such as Usto Mumin, whom realists would have regarded as avant-garde. Teaching styles during the early period were diverse, especially as in Uzbek cities, students learned from instructors who themselves disagreed over art forms. A student attending an art school, for instance, could receive instruction from both Benkov and an avant-gardist such as Kourzin.

Politically, this situation was problematic for the Soviet Union's Central Committee leadership. It is important to recall it was trying to further its economic control and authority during this period. Art lacked a focus on building a communist state at a time when the party was pushing for further economic control and working to solidify its authority. In addition, as Shelia Fitzpatrick's study has noted from the late 1920 s to early 1930 s, there were genuine concerns among the populace that the intelligentsia were unfairly privileged. Hence, the Cultural Revolution underway in the first part of the 1930s also served in "creating the new Soviet intelligentsia,", while officials played a balancing act of not criticizing these cultural producers too greatly. By 1932 , it was clear to Stalin and a small group of advisers ${ }^{8}$ that a definitive singular direction was needed to solve among their problems the disagreements that existed between realist and avant-garde artists. This led them to create socialist realism during a Politburo commission from April to May $1932 .{ }^{9}$

Shortly after the commission, the Central Committee put forward a decree called the "Reorganization of Literary and Art Institutions." The decree established that there

\footnotetext{
${ }^{7}$ Fitzpatrick, The Cultural Front, 118.

${ }^{8}$ Stalin, Kaganovich, Potyshev, Stetsky, and, perhaps most importantly, Ivan Mikailovich Gronsky, a journalist and leader of the organizational committee of the Writers Union, were amongst the group. See , Katerina Clark, et al., Soviet Culture and Power, 163.

${ }^{9}$ Clark, et al., Soviet Culture and Power, 163.
} 
was to be only one artists union per cultural form, effectively banning all other organizations. Certain groups such as the previously discussed Artists of Revolutionary Russia dominated the local union's memberships. However, despite this development, socialist realism as a policy would not become official until after the August 1934 Writers' Congress. ${ }^{10}$ The 1932 declaration simply states that artists would be required to show life with "artistic realism."11 Therefore, understanding the discussions that took place during the Writers' Congress are essential despite them being in a different art form since they represent the origins and the overall difficulties in applying socialist realism over the decades to come. In Uzbekistan, the connection to the Writers' Congress played out in the difficulties of combining a nationalist art form with socialist content.

\section{Creating Socialist Realism}

The discussions at the 1934 Writers' Congress highlighted a central disagreement that became apparent in following years - mainly whether one "clear set of tools" should be developed union-wide. The problem lay directly in how delegates at the conference were interpreting the new policy, allowing it to meld with the creation and encouragement of the nationalities. The result (as this section demonstrates) based on comments during the congress was that socialist realism was to be established based on Russian art works, although not officially in the early period.

The congress established several key points, among them a somewhat vague working definition of socialist realism. Writers were to create works that would demonstrate the "spirit of socialism" while representation of collective workers was also agreed-upon. The celebration of heroes also emerged as an agreed-upon theme. The

\footnotetext{
${ }^{10}$ Bulanova and Rosenfield, Soviet Disunion, 13.

${ }^{11}$ Sjeklocha, and Mead, Unofficial Art in the Soviet Union, 43.
} 
Congress revealed the first signs of the conflict between imposing a set of ideas and letting art flow naturally. At the Congress A. I.Stetsky, an important writer and speaker, declared:

Many of us try to be too clever about socialist realism. Socialist realism is not some set of tools that are handed out to the writer for him to make a work of art with. Some writers demand that they be given a theory of socialist realism complete in all its details. ${ }^{12}$

This statement acknowledged the lack of a set or clear policy, while revealing that some writers had been pushing for such a form of socialist realism. It also reveals that the writer - and by extension, artist - is required to pursue their own view point of socialist realism since it is "not some set of tools" to be given. Stetsky further confirms this when he states:

We are told that we must show socialist realism, there is only one answer which we can give here... socialist realism can best be shown in those works of art which Soviet writers produce. ${ }^{13}$

Therefore works that were created based on the spirit of socialism and displaying examples of collectivization elements could be deemed as examples of socialist realism. However, as it was also stated during the congress no resolution was passed which forced any artist to follow a particular path. ${ }^{14}$

Another important theme at the conference emphasized that there was in fact a correct art form mainly based on Russian works. Delegates did not state early Russian art's superiority clearly as such, but rather cited it as an example to aspire towards, unlike in later periods (1940s) where it was clearly stated as the correct method. The basis of these discussions seemed to be rooted in conversations from the tenth state congress of

\footnotetext{
${ }^{12}$ Maxim Gorky et al., Soviet Writer's Congress 1934: The Debate on Socialist Realism and Modernism in the Soviet Union (London: Lawrence and Wishard, 1977), 265.

${ }^{13}$ Ibid.

${ }^{14}$ Ibid., 265-267.
} 
the USSR (1922), where the concept of two groups - Russians and non-Russians - was significantly developed. The Russians were considered the advanced group, and the nonRussians deemed backward. The division between Russian and non-Russian was evident at the 1934 Writers Congress. An artist (writer) named Gusev told the Congress "that having worked with Uzbeks he was convinced of their work's lack of talent, the insincerity of their attitudes, and the rottenness of their literary milieu." ${ }^{\text {15 }}$ The implication for Uzbek paintings was that miniature artworks were deemed inferior compared to Russian classical realist works. The notion of Russian superiority only became more explicit in following years. Although perhaps the number of delegates explains more clearly the position that Central Asians held, with 41 delegates arriving at the congress compared to over 600 from across the Union. ${ }^{16}$

Following the congress, in October 1934, the Council of Peoples Commissars (CPC) of the Uzbek SSR immediately announced that it would provide funding to promote the creative work of painting that featured enterprises and farms. ${ }^{17}$ The funding reflected the new direction decided at the congress with the spirit of socialism and the promoting of industry as the primary functions of artworks. The CPC's concentration on farms in particular is interesting mainly due to the problems that were occurring at the time. 1934 proved to be one of the worst years for cotton yields, so much so that the authorities had to use larger amounts of chemical fertilizer to ensure a better harvest. ${ }^{18}$ Besides issues with cotton the country was also just starting to recover livestock, which

\footnotetext{
${ }^{15}$ Clark et al., Soviet Culture and Power: A History in Documents: 1917-1953 (New Haven: Yale University Press, 2007), 177.

${ }^{16}$ Allworth, Central Asia, 130 Years of Russian Dominance, 380.

${ }^{17}$ Iskusstvo sovetskogo Uzbekistana 1917-1972, (Moscow: sovetskii khudozhnik, 1976), 82. (hereafter cited as ISUz 1917-1972).

${ }^{18}$ Allworth, Central Asia, 130 Years of Russian Dominance, 289-290.
} 
had noticed a massive drop-off only two years before at the height of the collectivization campaign. ${ }^{19}$ The $\mathrm{CPC}$ also announced it would provide separate funds for paintings to be displayed in the upcoming "10 years of Uzbekistan exhibit" (1936), which given the timing included expectations for similar undertakings. ${ }^{20}$ The timing of the two funding announcements clearly demonstrates that the newly-envisioned socialist realist project was to be a lasting movement in the Republic.

However, just as the congress revealed disagreement over the extent to which members could dictate socialist realism and its connections to nationality, the preceding years in Uzbekistan would be equally confused, allowing for alternative interpretations of socialist realism to emerge.

\section{Impact of Congress in Uzbekistan}

Whether artists started to undertake socialist realism in Uzbekistan immediately is unclear based on existing sources. According to a Soviet book on Uzbek art published in 1957 by 1932 "many artists" were on the path of "socialist style realism" - an interesting feat considering the USSR had only started to undertake the socialist direction and it had not even been officially declared at that point. ${ }^{21}$ Another Soviet book also written in 1974 discussing Uzbek art from the 1930s describes it as displaying a "realistic map of life", that is adhering to the realist aesthetics. ${ }^{22}$ The latter book published in Tashkent, unsurprisingly similar to its earlier 1957 counterpart, emphasized success since an unsuccessful policy would have demonstrated flaws in Uzbekistan's development. Yet, according to many other sources including a document on the discussions of the third

\footnotetext{
${ }^{19}$ Allworth, Central Asia, 130 Years of Russian Dominance, 289-290.

${ }^{20}$ Ibid., 82.

${ }^{21}$ ISUz, 80.

${ }^{22}$ UzSSR, 398.
} 
session of the Academy of Arts (1949), Uzbekistan was a place of concern where decorativism or primitivism was still prevalent. ${ }^{23}$ The apparent contradiction was not unique to paintings; literature and other forms of creative expression also witnessed similar confusion. ${ }^{24}$ The art movements of the previous 1920 s and their influence in the early 1930s in part explain this interpretational challenge.

As discussed, in the 1920s Uzbekistan's art could be grouped within three artistic styles: avant gardist, realist, and a new hybrid style combining methods of the avantgarde and the regional miniaturists. The avant-garde painters aimed to continue pursuing artistic expressions with high degrees of abstraction, while the realists pushed for images based upon technical skills of representational depictions. The third group sought to harmonize traditional Central Asian forms into a more modernized art style. Artists debated what form and direction "art" should take in an emerging, modern Republic. The artists working in each of these stylistic directions knew each other and often worked together at the same schools. The lack of a dominant influential artistic movement meant that during this period (1920-1932), all three styles were presented to the public.

The experiences of painters living in 1930s Uzbekistan provides evidence of this triad and showcases the extent to which socialist realism spread. The ideal example of the duality is provided by Alexander Volkov, a prominent Uzbek painter born in the Fergana valley to parents of both Uzbek and Russian origin, and schooled in St. Petersburg (19061908), provides. Volkov, aware of the impact of the 1932 decision to create an official

\footnotetext{
${ }^{23}$ Sessii akademii Khudoznestv SSR, Tretiia, Sessiia Voprosy Teorii I Kritiki, (Sovetskogo Izobrazitel'nogo Iskusstva, 24 ianvaria - 1 fevralia 1949, (Moscow: Izdatel'stvo akademi khudoznestv, 1949), 129. (hereafter cited as SAsr).

${ }^{24}$ For a discussion of the contradictions within literature see Edward Allworth's discussion in The Modern Uzbeks, Chapters 5,9 and 15. For discussion of this same phenomenon in music see Tomoff Kiril Uzbek Music's Separate Path: Interpreting"Anticosmopolitanism" in Stalinist Central Asia, 1949-52, and Alexander Djumaev. "Musical Heritage and National Identity in Uzbekistan." Ethnomusicology Forum 14 no. 2 (November 2005) (43-50).
} 
Artist's Union, decided to switch his works to avoid possible scrutiny. Shortly before the official declaration of social realist art in 1933 he told an Uzbek newspaper:

Although I am changing my artistic approach I don't want to lose the rich tones and colourfulness that characterizes my earlier work. I want to create simple, bright pictures reflecting contemporary life that people... understand. ${ }^{25}$

Volkov began changing his artwork to incorporate industrial elements. The works still contained the rich colours that he had sought, but also showed common signs of labour and industrialization, which socialist realism required (Fig.3). They were a celebration of the Soviet state that could be easily understood by a mass audience. His depictions of the 1930s showed images of collective farming in particular, which included tractors and perhaps most importantly a mixture of women and men labouring together.

However there is more to Volkov's earlier 1932 works. His statements after the adoption of socialist realism point clearly to his full intent and his clever reinterpretation of socialist realism, taking advantage of the lack of definition. In 1935, Volkov discussed his work as follows:

The painting of the East is built chiefly on the primitive and on a painterly, decorative beginning. This is the basis of my work. Elaborating works of primitive flatness, I have introduced a whole system of triangles and other geometric forms and arrived at the depiction of man based on the triangle, that being the simplest of form ${ }^{26}$

At the time Volkov had finished a series of paintings began in 1932, which incorporated industrial themes, later praised by Soviet critics as describing the "Soviet

\footnotetext{
${ }^{25}$ A. Volkov, "My zdes' tol'ko kochevinki," 41.

${ }^{26}$ Bown, "Painting in the Non-Russian republics," 144.
} 
reality."27 The East, for Volkov, was his Uzbek Republic and the earlier works were quite literally a system of triangles as displayed below in the painting Uzbek cart (Fig. 4). Volkov's description of the East as having been built on primitive and decorative beginnings warrants further discussion. According to Bown's interpretation of the quote it represented a clever way for Volkov to use the past Russian imaginings of the East as a way for him to continue painting in a less rigid fashion. ${ }^{28}$ Critics at the time specifically targeted decorative $\mathrm{e}^{29}$ works and so by tying them to the "national" definition of art Volkov would provide himself some protection allowing for his continued artistic experimentation. As his 1933 statement indicates, Volkov did not want to lose the "rich tones and colourfulness" of his past works.

However, Volkov's description extended beyond his own benefit and would be used to support the early works of other painters including Ural Tansykbaev and Nikolai Karakhan and even to an extent Usto Mumin. Volkov's reference to "primitive flatness" was almost certainly a link to miniature art, with its previously mentioned twodimensional representations. The positioning of these works as part of Uzbek culture allowed for works by these painters to continue with the depicted blended designs for a time at least. Most of the works by these painters would by the end of the Second World War have dropped miniature influences.

After 1934 Volkov's work did change, but he "benefited from the certain degree of creative lee-way grated to artists in the Republics," paintings within the Republic that were "national in form". The important mantra at the

\footnotetext{
${ }^{27}$ Gregor Gallery, The Volkov Dynasty, (Washington, Gregor Gallery, 1997), 7.

${ }^{28}$ Bown, "Painting in the Non-Russian republics,"144.

${ }^{29}$ See Bulanova and Rosenfield Soviet Disunion.

${ }^{30}$ Gregor Gallery, The Volkov Dynasty, 7.
} 
time of "national in form socialist in content" was meant to convey the idea that Soviet culture was to incorporate local or nationalized elements, while at the same time subscribe to socialist aims of unification. The combined form would in turn create a new socialist art that would be socialist realist.

Volkov's works shift into a more formulaic style and began to incorporate images of cotton, landscapes, workers and daily life. Volkov's Cotton Girls (Fig.3), completed in 1939-1940 depicts the picking of cotton, for example. The painting is a rarity even for Volkov with its inclusion of smiling people, although its clear depictions of people's faces were a hallmark of his works at the time.

Other pieces by Volkov painted during the period incorporated construction sites, workmen building structures or cotton cultivation. Soviet critics at the time interpreted them as "grotesque formalism" although he was still permitted to continue painting them. "Grotesque formalism" was a reference to the work's supposed ugly depictions of the Uzbeks - which was not acceptable, since it "distorts the pure image of the Soviet people who engage in building communism." ${ }^{32}$ The pure image the Soviets had envisioned was based upon their expectations of what Uzbeks were supposed to resemble and from Moscow's position these works did not comply with their own imaginings. Hence, despite the efforts to show Uzbeks contributions to building communism these works were viewed critically.

Another major painter during the period was Ural Tansykbaev, an Uzbek artist who was born in Tashkent. In 1928, he had studied at a small school in Penza, a city near Moscow; there he learned the traditions of Russian realism from instructors I.

\footnotetext{
${ }^{31}$ Ibid., 8.

${ }^{32}$ Bulanova and Rosenfield, Soviet Disunion, 21.
} 
Goryushkin-Sorokopudov and N.Petrov. Although his work does carry some influence from his instructors during this time it has been argued that it had greater influence from Western European artists such as Gauguin. ${ }^{33}$ Like Volkov, Tansykbaev's influence from European painters was grounded in some exposure to European artists. After his studies the painter travelled to Moscow visiting museums, notably the Museum of Modern Western Art. ${ }^{34}$ It is during these visits that his appreciation for Western-European artistry flourished and was likely the greater source for inspiration, even over his previous studies.

Tansykbaev returned to Uzbekistan in the 1930s where he undertook works which were bright and simple interpretations of scenes ranging from abstract gatherings of people to landscapes. One of the more significant pieces completed in 1931, Crimson Autumn (Fig.5), demonstrates a clear influence from European techniques and is likely one of the sources for the connections to Gauguin's bright works. The work is one of the clearest examples of hybrid imagery in Uzbekistan art combining styles from multiple sources.

In 1932, he became a member of the Union of Artists of Uzbekistan. On September 24, 1934, his works gained prominence at one of the most significant exhibitions of the time, held in Moscow when he was credited as being "the leading Uzbek colourist. ${ }^{, 35}$ The comments can be viewed as part of a general lag in the enforcement of the new socialist policy, which had only been declared less than a week before. Given the timeline and comments made during these exhibits artists such as

\footnotetext{
${ }^{33}$ Akhmedova Nigora, Ural Tansykbaev: Selected works of Soviet artists - Introductory section (Moscow: Sovetsky Khudozhnik Publications, 1989), n.p.

${ }^{34}$ Ibid.

${ }^{35}$ Akhmedova, U. Tansykbaev :Selected works, n.p.
} 
Tansykbaev were able to display their works without criticism, despite a policy that directly challenged their work's existence. This allowance was due in no small part to the continued efforts by Volkov to link to the Russian imaginings of the East.

The works the Soviets started to promote were a reflection of the new policy. Tansykbaev's more famous works of the period including "Emancipation of Women" and "Nomadic" are worth noting mainly due to their subject, which corresponded with expectations at the time of Uzbekistan. The depiction of women as being freed by the Soviets also started to fit into the socialist "reality" even during this early period. However, there was disconnect between what the Soviets wanted to demonstrate and what had transpired. The hujum, as previously discussed, backfired with many women still wearing their veil even after the campaigns. Nevertheless the works were criticized because they did not fit the realist styles that were being encouraged. His works attracted so much attention that the State Museum of Oriental Cultures purchased two of his paintings in 1934 and included them in one of its an exhibitions entitled "Art of Soviet Russia" to be opened in Philadelphia in December later that year. ${ }^{36}$

Tansykbaev's praise was short lived. Soon after the declaration of socialist realism, his works began to attract criticism. Similar to other Uzbek painters, the recurring criticisms by critics of the time was that the colour usage was too bright. As one biographer of Tansykbaev has written, "to some northerners the dominant colours of

\footnotetext{
${ }^{36}$ M.V. Miunts et al. Ural Tansykbaev: vospominaiia dokumenty, (Tashkent: Gafura Guliiama, 1988), 42. (hereafter cited as Ural Tansykbaev: Vospominaniia),27.
} 
Tansykbayev's works seem too sugary." ${ }^{.37}$ Soviet critics felt that Central Asian "reality" could never appear in a bright or colourful representation.

Tansykbaev, along with N. Karahan, were two of the more notable artists for their canvas colours during the period. Soviet Artist K.F. Huon, upon examining their works at the previously mentioned Moscow exhibit (1934) concluded in an orientalist view that they had made valuable contributions to "international" art, which depicted the "colourful east." ${ }^{\text {38 }}$ This fixation on the colours of canvases seems to be a primary attraction of Uzbek art during the period up to and including part of the Second World War. In the pre-socialist realism period, use of colour was something to be admired and to be celebrated as the previous comments suggest. After socialist realism was declared, it began to become the main focus of criticism regarding most paintings from Uzbekistan.

As Said writes a major component within the Orientalist's outlook is the need to identify the Orient, as a colourful place in contrast to a bland "grayish tonality" associated with Europe..$^{39}$ Art critics from the 1930s, who lived in Uzbekistan, did not report such issues. Therefore a difference did exist between reviewers in Moscow or Leningrad and viewers in Uzbekistan. This is exemplified by the art critic V.Chepelev writing in the 1930s who argued:

What unites these young masters artistically ${ }^{40}$ : it is a firm realistic, broad handling of the form and constant attention to the problems of colour. To a great degree the tonal schemes are decorative though this does not deprive the image of the clarity of outline and meaning. For all individual distinctions, each artist bases his method on a wholesome, joyous view of the world. ${ }^{41}$

\footnotetext{
${ }^{37}$ Akhmedova, U. Tansykbaev: Selected works, n.p.

${ }^{38} \mathrm{MIUz}, 12$.

${ }^{39}$ Said, Orientalism, 185.

${ }^{40}$ The statement was made in reference to a review on the works of the members of the New East, which included Volkov and Tanskbaeyev among others.

${ }^{41}$ Akhmedova, U. Tansykbaev :Selected works, n.p.
} 
V.Chepelev's description of a broadly understood form and realistic elements within the works of the period was the most important point for him within the artwork. The review from a critic in the Uzbek SSR downplays the importance of the colour's "tonal schemes" and "decorative" nature. Chepelev's emphasis instead is on the "realistic" and its "clarity of outline and meaning," differentiating him from critics who resided outside of Uzbekistan. The ranges of colour schemes were not an issue so long as the form could be understood. The artists after all had imbued their works with a "wholesome, joyous view of the world" celebrating the virtues of the socialist system that the Soviets wanted. The statement is also markedly different from Volkov's musings linking the styles to the region. Chepelev does not mention the East, only suggesting what local painters were attempting to undertake within their works, a counter assessment of the ideas of socialist realism. It provides in my assessment the best evidence that a localized interpretation of socialist realism existed, one where form and clarity of meaning were more important for the painting than a concentration on colour.

Thus the 1930s established the beginnings of socialist realism. Fault lines concerning its possible limitations were already appearing. Tansykbaev would continue with major displays of his work in international galleries, as a result of the lag in enforcement of the policy. Volkov would reposition his own works to ensure that not only he, but other painters would benefit from leeway based on Russian imaginings of Uzbekistan. Finally, Chepelev would offer another interpretation of socialist realism positing an emphasis on clarity of meaning and form rather than colour. In the next chapter we will examine further the ramifications of this early development of socialist realism. 


\section{Chapter Five: Challenges of the Late 1930s}

In his seminal analysis of the late 1930s historian J. Archibald Getty has argued that the Stalinist purges were not uniform and cannot be viewed as a single event. ${ }^{1}$ The implications of this were important since they contrasted to other historical accounts that argue a single plan directed from above was responsible for the terror. ${ }^{2}$ Instead Getty's work demonstrated the party was a "disorganized and cumbersome machine", with conflicts over the direction of the USSR making "large-scale political violence possible and even likely." ${ }^{33}$ These tensions over future directions were apparent within paintings and the politics of art in Uzbekistan. They led to the rather confusing removal of paintings from galleries and the arresting of artists in the Republic, often with very little explanation for the actions. The Soviets at the same time began promoting the importance of galleries located in Europe through sponsored trips. This chapter argues these measures can be understood as ways of influencing and creating a new definition of art on an All Union level, compared to a localized regional understanding.

\section{Artist Arrests and Promotions}

In 1935, Usto Mumin was arrested for his artwork and its non-conformity with official doctrine, thereby striking a temporary blow to the artist's movement, which had aimed to harmonize the indigenous art forms with more traditional European artistic methods. The painter had been open to harsh criticism for his works, which depicted bocha or bacheh, young Uzbek boys who acted as dancers. Bachehs were highly problematic for the Soviets, since they clashed with Soviet notions of gender and gender

\footnotetext{
${ }^{1}$ Getty, J. A. A, Origins of the Great Purges: the Soviet Communist Party Reconsidered, 1933-1938. (Cambridge: Cambridge University Press. 1985), 6.

${ }^{2}$ Ibid., 198.

${ }^{3}$ Ibid.,206.
} 
roles. Bachehs, being difficult for the Soviets to define or understand, ${ }^{4}$ led officials to simplistically identify them as homosexual dancers. ${ }^{5}$ Homosexuality, taboo in the USSR, prompted officials to arrest Mumin on a visit to Moscow. Nevertheless, his sentence only lasted several months. He was soon released and made an "extensive report of the state, needs and prospects of popular art" to the Organization Committee of the Artists Association of Uzbekistan. ${ }^{6}$ The contrast between arrest and the writing of a report, several months later provides the first evidence of the haphazard nature of the period.

Confusion over the application of socialist realism becomes even more apparent with the censorship of artists, who, it seems, were painting in different, but presumably more acceptable styles than Usto Mumin. During this early period of Social Realism these different styles presented a challenge for determining if they complied with socialist realism, since the artists works helped guide the policy. Benkov's work "Waters" was removed from Moscow's Tretyakov Gallery, as were several of his other works from galleries across the USSR. ${ }^{7}$ Another realist painter and instructor originally from Russia and active during the time, L. Bure, also saw some of his works removed from gallery spaces. ${ }^{8}$ Therefore the decisions to limit or exclude paintings from gallery spaces were not based upon a set criteria at least not based on styles. The answer may be that the works were discarded in favor of depictions that more closely resembled state promotions at the time such as farming.

\footnotetext{
${ }^{4}$ In his study of Soviet dance Shay suggest bachas fit the definition of "bisexual" citing historical descriptions, with the young men desired and engaged in relationships with both sexes. See Anthony Shay, "Choreographing Hypermasculinity,"240.

${ }^{5}$ Ibid.,211-238.

${ }^{6}$ R.V. Eremeh et al., A.V. Nikolayev, 28.

${ }^{7}$ P.P Benkov 1879-1949 VP, 163.

${ }^{8}$ Ibid.
} 
Mikhail Kourzin, the previously discussed avant-garde painter and member of the artists of the New East, was arrested in 1936 and accused of violating the artistic aesthetic of the regime. He spent ten years in Siberia for subversive activity. At the time, his works were highly critical of capitalist society, but were also highly abstract, resembling works by German painters, which explains why the paintings attracted the attention almost immediately of government censors. However, his art was only part of the issue that attracted the attention of officials in Moscow. The justification for his arrest actually came from rumors that he had threatened to overthrow the government in Moscow. It was based on a story that had circulated at the time that Kourzin had told painters that they needed to kill Stalin and overthrow the government. ${ }^{9}$ The threat was likely a trumped up charge, since corroboration was limited for the accusation. Volkov, who had known Kourzin from his involvement in the New East was pressured to testify that Kourzin's activities were anti-Soviet, a fact that was not known until recently. ${ }^{10}$ Following Volkov's testimony Kourzin stated he was intoxicated during his anti-Soviet activities. ${ }^{11}$

The events of the mid-late 1930s were not limited to specific artists, with whole exhibits targeted throughout the Soviet Union. A 1935 exhibit in Tashkent displaying paintings from many major contemporary $\operatorname{artists}^{12}$ had most of its works destroyed with no explanation. An account of the exhibit only states that many works did not survive, but does not provide further details. ${ }^{13}$ Local newspapers reporting on the

\footnotetext{
${ }^{9}$ The Desert of Forbidden Art.

${ }^{10}$ Ibid.

${ }^{11} \mathrm{Ibid}$.

${ }^{12}$ The exhibit lists a number of painters. Bahram Hamdam, Alexandre Volkov, N. Karahan,Tansykbaev and a few minor artists are also mentioned, including V. Markova. Curiously, the exhibit fails to provide full list of the number of participants, which was often the highlight in exhibitions during the Soviet Union before even listing the art works displayed.

${ }^{13}$ ISUz 1917-1972, 88.
} 
exhibit generally complained about many of the works, "in particular the colour," 14 which was likely described as too bright and may have played a contributing role in the destruction of the work.

As painters were being imprisoned and works destroyed, artists were left asking themselves: what was deemed acceptable? The Soviets answered by creating the Central Arts Committee (1936). The Committee, created by Platon Kerzhetsev, received ultimate authority over all forms of art in the USSR, although in practice like in previous periods its policies could be overridden by Stalin. The committee reinforced most of the established elements of socialist realism and began to create local committees including the Organization of the Artists' Association of Uzbekistan.

The increased promotion of socialist realism led the Soviets to fund a major study trip for young Uzbek art students in 1936 to go to Moscow and Leningrad to visit museums and learn about Russian and European masters. Tansykbaev and Hamdam were listed as having participated on the tour, while other names are not given. ${ }^{15}$ The goal was evidently for the students to learn about the past realist painters and transpose that knowledge into their own work. Tansykbaev's own writings from the period, which I examined, contained no reference to the trip. This may be in part due to the fact he was travelling extensively throughout the Soviet Union at this time. His artworks during the period seem to tell reflect this fact. He begins during the late 1930s undertaking landscapes, the genre which eventually replaces his previous works. Landscapes, as a more accepted art form, may have contributed to this move.

\footnotetext{
${ }^{14}$ Ibid,.88.

${ }^{15}$ Ibid,.89.
} 
However, despite the trips that were being provided to some painters, on the whole, we know the funds flowing to the artists inside the Uzbek Republic were extremely limited during the late 1930s (1936-1937). The newly formed Union of Artists of Uzbekistan, based in Tashkent, functioned on a local level to facilitate the spread of socialist realism throughout the country, providing an ideal example of this lack of funds. The Artists Union's resources had only a building on Pushkin and Gogol streets that had four rooms, two of which were offices. ${ }^{16}$ Although this building's location was important functionally, the space was inadequate. The group was reduced to creating makeshift exhibits described as taking place in the hallways during the evenings with capacity reached with the artists and their wives. ${ }^{17}$

The implications of having these state funded trips while there was a lack of funding for artists in the Republic must have been confusing, perfectly illustrating Getty's described wonky political machine. The Soviets would fund travel to learn about the artwork that the state wanted undertaken, but then return them to inadequate spaces to either conduct or show works. There was a message to artists mainly that the European cities with their galleries were more important. An official must have clued into the mixed messages, eventually, since funds began to suddenly flow to artists' organizations in the Republic.

On May 20, 1938, Uzbekistans'Council of People's Commissars and its central committee enacted measures to "promote the arts in Uzbekistan". ${ }^{18}$ These measures included studio training provided by the newly formed Union of the Artists of Uzbek

\footnotetext{
${ }^{16}$ P.P Benkov 1879-1949 VP, 172.

${ }^{17}$ Ibid., 172.

${ }^{18}$ Ibid,.182.
} 
SSR. ${ }^{19}$ In contrast to the previous periods students and artists were to be granted studios instead of the confined spaces previously given. The new measures also called for an advanced training studio to be opened in Samarkand, through that would not be opened until the summer of $1949 .{ }^{20}$

The 1938 Uzbek SSR measures coincided with the rise of a young Soviet star in Moscow, Andrei Zhdanov, who emerged as the premier lieutenant of Stalin's cultural advisors. ${ }^{21}$ Although the relationship between Stalin and Zhdanov is complex, and while Zhdanov developed his own theories and beliefs concerning the "correct" way of conducting art, he was nevertheless constantly changing his own views to suit those of Stalin. This is particularly true during the post World War II period. ${ }^{22}$ However, during the thirties and early forties Zhdanov would have limited time to directly impact the paintings, although he made many declarations against what he called "non-patriotic art" prior to the outbreak of the Second World War. These declarations would have implications for art in the Republics, as it furthered the definition of art and the type of painters the Soviets aimed to promote.

At the Eighteenth Party Congress in Moscow (1939), Zhdanov praised the creation of a new intelligentsia and efforts towards creating new cultured citizens, ${ }^{23}$ which could be linked to developments such as the 1938 Uzbek resolution. Officially, the party would promote and support artisans who had or could rise from lower classes. ${ }^{24}$ This was done as the party criticized the previous generation. The goal was to

\footnotetext{
${ }^{19}$ P.P Benkov 1879-1949 VP, 182.

${ }^{20}$ Ibid.

${ }^{21}$ Clark, et al, Soviet Culture and Power, 212.

${ }^{22}$ Ibid., 254-263.

${ }^{23}$ Fitzpatrick, The Cultural Front, 178.

${ }^{24}$ Ibid.
} 
encourage and replace the cultural leaders that were being targeted across the USSR during the purges, with a younger generation. However, this formation of rising class could only happen in certain geographical areas and only if the artists were undertaking works that dealt with permitted subjects.

\section{Promoting Images of Industrialization}

The key goal of creating works that supported the regime continued in the period. Fyodorov-Davydov, an art critic at the time, would write "now it is important that the changing aspect of the country, all the new features that appear in its life be perceived and reflected as poetical aesthetic values." ${ }^{25}$ Paintings would need to showcase the "changing aspects of the country" explaining why there seems to be an emphasis in artworks depicting mass spectacles ${ }^{26}$ of technological and social development. The funding and state support was provided to those artists that emphasized the spectacle experience.

The building of the Fergana Canal specifically became the focus of a contingent of artists including Organes Tatevosyan and Bahram Hamdam sent by the Artists Association of Uzbekistan committee to document the project. The project started in the summer of 1939 and involved over one hundred-fifty thousand workers mostly unpaid Uzbeks, who dug the hundred and sixty-eight mile canal in forty-five days. ${ }^{27}$ News reels and mass photography campaigns captured the project. Photographs captured the masses of people involved within the project rather than concentrating on individuals. In a letter

\footnotetext{
${ }^{25}$ Ginsbury, Ural Tansikbayev, 8.

${ }^{26}$ I define mass spectacles as large undertakings meant to show case Soviet achievement. The Fergana Canal fits the category since the project employed a massive number of people and was heavily documented by film, photographs, and paintings.

${ }^{27}$ Allworth, Central Asia 130 years of Russian Dominance, 294.
} 
written at the time concerning the Fergana Canal project officials claimed "art has helped to dig the canal." 28

The paintings that emerged from the project presented a similar depiction that focused on unnamed masses, but in a slightly altered manner. Paintings depicted workers mainly in a similar fashion and emphasized the goal of moving towards a commonpurpose, the industrialization of Uzbekistan. Despite "hardships" and grueling hours that ensued over many of the construction programs, ${ }^{29}$ the paintings never depicted any of these challenges. Instead these showed only the success of the construction projects. Soviet promotion of these works points to the state's desires to emphasize the progress that was being made in the Republic and the successful building of communism.

\section{The Case of Two Exhibits}

The state of art within Uzbekistan by the end of the decade can be summarized by two exhibits: the All Union Exhibit (Moscow) and the National Art Exhibition (Tashkent), which both took place in 1940. The pieces that were included and those that were excluded demonstrated the kind of paintings deemed acceptable and which artists were permitted to display at an all-union level as opposed to the national level.

The National Art Exhibition, which took place in Tashkent, included over 100 artisans. In order to guarantee that enough works could be displayed, the definition of what could be considered art was expanded to include "folk art" items ranging from leather, textiles to wood carvings. ${ }^{30}$ It reflected in part Zhdanov's and other officials' promotion of the arts from non-traditional intelligentsia, but it also reflected the fact few painters would have been present. The expansion of the definition of what constituted

\footnotetext{
${ }^{28}$ ISUz, 97.

${ }^{29}$ Allworth, Central Asia 130 years of Russian Dominance, 294.

${ }^{30}$ ISUz, 93-95.
} 
fine arts nationally contrasts sharply to the All Union Arts exhibition in the same year. The All Union exhibition's major theme was the image of the Soviet man and was exclusively open to more traditional European interpretations of visual arts. This meant significantly lower participation with only 50 painters partaking in the event in total, including an unknown number from Uzbekistan.

A partial explanation for the different approaches can be found in art historian Susan Reid's evaluation of the Moscow exhibition Industry of Socialism. The exhibition originally conceived in 1936 - was slated to open in 1937 , but due to the denouncements of some of the show's participants would not actually open until 1939. A central debate within that exhibit's construction concerned the definition of art, whether to include textile, ceramics and other forms of art. Some artists such as Mariia Nazarevskaia and Evgenii Katsman argued in favor of including textiles specifically since they argued they contained "figurative elements."31 Reid notes that by marginalizing art forms in particular textiles and illustrations for children's books, the Soviets "relegated" those art forms predominated by women to the domestic sphere, feminizing them in the process. ${ }^{32}$

The definitions of the arts allowed for the institutionalization of Orientalist power structures. The prioritized art form at the Union level would be paintings and on the national level it could be textiles, miniatures and lithographs. All Union displays could show "art", while displays in Uzbekistan could show "national" or "Uzbek" art. As Said would describe it, "[T]his vision in a sense created and then served the two worlds thus conceived. Orientals lived in their world "we" [Soviet] lived in ours.",33

\footnotetext{
${ }^{31}$ Susan Reid. "All Stalin's Women: Gender and Power in Soviet Art of the 1930s." Slavic Review 57, no 1 (1998): 161.

${ }^{32}$ Ibid., 162 .

${ }^{33}$ Said, Orientalism, 118-119.
} 
For Uzbekistan, the resulting designation of art meant significantly diminished representation at All Union events. Iskander Ikramov, one of the active book illustrators of the period, was marginalized from All Union exhibits. His works were shown in 1930 as part of Uzbek literature at the Central House of Writers and internally in Uzbekistan. However, he would not be permitted to join the Uzbekistan Artists Union until 1959, becoming the head of the group at the same time. Similar to other book illustrators his works were not considered to be art by the All Union definition and therefore were marginalized.

Although no exact numbers are given for participation at the 1940 All Union exhibition, only five pieces were actually discussed in the official account of the exhibition from an Uzbek perspective. ${ }^{34}$ The low numbers suggest that there was a limited number of Uzbeks, who jurors deemed were capable.

Benkov was among the artists permitted to participate with his painting of a farmer, while V Kaydalova-a lithographer who had completed a work of the Central Asian poet Alisher Navoi-also participated. ${ }^{35}$ The lithograph in fact won second prize at the exhibit for Kaydalova's "realistic" portrayal of the poet, ${ }^{36}$ an odd description considering Navoi had died in the Fifteenth Century. It may, be that the lithograph depicted the way officials idealized or imagined the poet. ${ }^{37}$ In contrast, a work submitted by Tansykbayev of the poet undertaken in a miniature style was excluded from the

\footnotetext{
${ }^{34} \mathrm{ISUz}, 100$.

${ }^{35}$ Alisher Navoi was a fourteenth century poet, who the local Uzbek intellectuals in the late 1930s began to re-imagine as the founder of Uzbek writing. For a complete account see Allworth's discussion in Modern Uzbeks, 223-231.

${ }^{36} \mathrm{ISUz}, 100$.

${ }^{37}$ This is difficult to judge because I have not seen the lithograph in question and can only speculate based on the juries' description of the work as "realistic".
} 
exhibit by the jury since it failed to "follow the path of compliance". ${ }^{38}$ Despite the juries" dismissal of Tansykbayev's work, the piece still demonstrates that artists continued to paint in a non-realist style and be considered for submission to official exhibits, even if the works failed to receive official standing.

Kaydalova's works would always be accepted among the juried art exhibitions of the later part of the decade regardless of location whether in Moscow, Tashkent or Samarkand. Kaydalova's largest series of lithographs were mainly of streets in Tashkent, capturing examples of the advances within the Soviet city and served as propaganda of the virtues of the Soviet system. They were displayed even late into the Khrushchev period as officials showcased the benefits of the Soviet system to visitors from abroad. Kaydalova's lithographs had captured the ideal formula for visual arts of the period. The works needed to show progress, but in a realist fashion.

Therefore the late 1930s played a significant role the furthering the definition socialist realism and by extension in defining arts in Uzbekistan. The works of painters would need to conform to this increasingly limiting definition of artworks. Painters from Uzbekistan were permitted to continue working in non-socialist realism styles, but their paintings would not be accepted at a Union level - limiting their opportunities for exhibition. However, the implications for these changes would materialize immediately with art policy in the Republic becoming less rigorous, as the threat of war loomed.

${ }^{38} \operatorname{ISUz}, 100$. 


\section{Chapter Six: From Moscow to Tashkent: Interactions during the Second World}

\section{War}

I hope that you will not regard Tashkent as a room to wait out the end of the war, but that it will be a native home for you, which you will remember for the rest of your life.

- Khamid Almidzinhan, head of the Uzbek Union of Writers to dramatist Aleksander Deich. ${ }^{1}$

The focus of resources and concerns toward military needs during World War II limited the state's ability or willingness to persecute artists who were producing artwork outside of established norms. This allowed artists in the Soviet Union, including those in Uzbekistan-to produce works, for example, ones similar to those in Europe or North America at the time. Rather than constituting art that was radically different either stylistically or in subject matter, Soviet wartime works served more as documentation of the war and sometimes as propaganda. Although lacking the same level of scrutiny as previous periods, the war period nonetheless led to future scrutiny of Uzbek arts. It created the circumstances that allowed for the eventual construction of key artistic institutions of learning and marked the beginning of increased interactions between Uzbek artists in the major cities of the Republic and other areas of the Soviet Union. The barriers that had existed due to geographical distance, creating a degree of separation between regions, were altered significantly during the war - allowing for direct exposure between amongst the various Soviet painters.

\footnotetext{
${ }^{1}$ Rebecca Manley, To The Tashkent Station: Evacuation and Survival in the Soviet Union at War (London: Ithaca and Cornell University Press, 2009), 246.
} 
The lack of official scrutiny and any artist's records during the war makes the study of this period problematic. Records that officially documented the exhibits are extremely limited. Informal records of official meetings, individual recollections, and secondary source data nonetheless provide evidence that the exhibits did take place, which in itself is significant. These sources reveal that artists' experiences were starkly different from the daily struggle of city residents and evacuees, as will be discussed throughout this chapter.

\section{Two Evacuation Experiences}

In 1941-1942, as the German army advanced into the Soviet Union, a large portion of the population from cities in the USSR, particularly in its Western sections were moved to areas in Central Asia. Students and staff working in Soviet art institutions were evacuated from a number of Russian cities to Tashkent. Many artists who were relocated expressed a desire not to leave for the Uzbek SSR due to safety and food supply fears spread amidst rumors of what lay ahead for them in Tashkent - a city portrayed as backward, even though more desirable than other Central Asian cities. ${ }^{2}$ According to a written account before the war by Isaak Bakhamatov, "[T]ashkent is overflowing with refugees, overflowing with writers, overflowing with artists, overflowing with Muscovite factories, organizations and educational institutions." Given the description and its apparent connections to Moscow, an evacuee might assume that the Soviet Central Asian city would provide an easy adjustment.

The evacuees upon arrival in Tashkent were met with issues ranging from housing space to obtaining permission to remain in the city. Many who had family or friends who

\footnotetext{
${ }^{2}$ Stronski, Tashkent: Forging A Soviet City, 95.

${ }^{3}$ Manley, To The Tashkent Station, 160.
} 
lived or had evacuated there followed them, and Tashkent was inundated by the numbers of people it received. Although many arrived with documents and jobs valid for the city they were turned away and forced to travel elsewhere in the Republic. Other citizens resorted to illegally staying in Tashkent avoiding night patrols, which were deployed to remove illegal inhabitants. ${ }^{4}$

Arriving artists received much better treatment than their fellow Uzbek colleagues. Most of Tashkent's art institutions were cleared of their former occupants, becoming workspaces and homes to elite groups, such as the Moscow-based Writer's Union. ${ }^{5}$ The local artists who were forced out of these workspaces often had to relocate outside of Tashkent or to an entirely different city, often Samarkand. The buildings of Tashkent's academic institutions that were not used to house the new arrivals were otherwise converted into factories for the war effort.

Tashkent's treatment of different artistic fields was particularly interesting and demonstrates a hierarchy in the arts. Perhaps most telling of the kind of favoritism that was shown to the arriving artists was that of Anna Akmatova, a famous poet whose work had been banned by Moscow after a series of events that included her husband's alleged involvement in an anti-Bolshevik plot. Despite her controversial reputation, she was provided with space in Tashkent, albeit only after the intervention of fellow writer Lydia Chukovskaia. Her accommodation seemed to illustrate that at least part of the criteria for lodgings in the city was dependent upon having appropriate political and societal connections. ${ }^{6}$ Thus there was a pecking order concerning who would be given priority

\footnotetext{
${ }^{4}$ Manley, To The Tashkent Station, 191-194.

${ }^{5}$ Ibid., 92.

${ }^{6}$ Ibid., 158 .
} 
for space and housing. Evacuated artists clearly went to the head of the line, while local artists were given less serious consideration.

However, not all of the art organizations or individuals transitioned smoothly into the city, as a conflict of interest existed between officials in Moscow and those in Tashkent. ${ }^{7}$ For example Alexander Fadeyev, the chairman of the Writer's Unionobtained permission for himself and a list of writers to relocate only after sending a telegraph to Tashkent shortly after the announced evacuation. ${ }^{8}$ In contrast, the Muscovite Theatre of the Revolution which arrived without making the same arrangement was "initially denied registration". ${ }^{9}$ Despite assertions at the time that officials were trying to "preserve the inviolability of local theaters", ${ }^{10}$ the reasoning for rejections can be explained as relating to the overall problems experienced during the relocations, which ranged from housing to food shortages.

Meanwhile in Samarkand, many of the major artistic groups arrived from abroad -including the Russian Academy of Fine Arts, the Moscow Art Institute, and the Kiev and Kharkov Art Institutes. Since personal connections to other artists played an important role in relocation, Samarkand and its large artist community made it an ideal place for evacuees. The Registan - the centrally located building in the heart of the city became the home for many of the arriving artists: particularly those from the Kharkov Institute. Artists such as Volkov provided a home for former pupils arriving from Tashkent who were forced from their workspaces.

\footnotetext{
${ }^{7}$ Manley, To The Tashkent Station, 156.

${ }^{8}$ Ibid.

${ }^{9}$ Ibid.

${ }^{10}$ Ibid.
} 
Benkov, in his role as the head of the local artist union, was able to interact with many of the newly arrived evacuees and institutes and often participated in events organized by the groups. Although many of the same problems existed in Samarkand as in Tashkent, it seems from an artist, standpoint that conditions were moderately better when compared to Tashkent. Classes continued for the newly arriving pupils and several graduations took place before the war's end. ${ }^{11}$ Hardships nonetheless affected artists. Benkov fell seriously ill during the period and fortunately recovered, while the now famous Russian sculptor Ernst Iosifovich Neizvestny-who was studying at the time in the city, nearly died of typhus. ${ }^{12}$

Despite the hardships faced by the populace in wartime Tashkent and Samarkand, the Soviets still tried to promote arts and culture. As Stronski notes, newspapers continued their efforts to promote culture in Tashkent throughout the war "at least in rhetoric." ${ }^{\prime 13}$ However, the number of exhibitions of paintings undertaken in this period suggests there was more support than mere rhetoric. In fact, painting exhibits seemed to have flourished during the war. Two large exhibitions took place in Tashkent: one in 1943 and a second, entitled Art of Uzbekistan - 20 Years (1945). Several exhibits also reportedly took place in other areas of the country, totaling roughly twenty-five. ${ }^{14}$ However, the justification for these exhibitions was likely with the goal of promoting the war effort in much the same way as poster art was being used in Europe. This is also based on evidence of a genuine desire to use the arts to provide a degree of relief for the

\footnotetext{
${ }^{11}$ Leon, Centaur: The Life and Art of Ernst Neizvestny, 37.

${ }^{12}$ Ibid, 37.

${ }^{13}$ Stronski, Tashkent Forging A Soviet City, 130-134.

${ }^{14}$ ISUz 1917-1972, 176.
} 
populace. In that same period Uzbek dancers were dispatched to entertain soldiers ${ }^{15}$ and provide mental relief.

The previously mentioned 1943 and 1945 Tashkent exhibitions attracted artists, who had presented together in exhibits before the war: Tansykbaev, Benkov, Volkov, Tatevosyan, Ufimtsev, Karahan, and Kashin. The exhibits also included some of the country's new generation of painters who would contribute to the future production of art works including Kovalevskaya, L. Abdullaev and A. Abdullaev. There is also mention of the participation of a number of painters from Moscow, Leningrad and Kiev, although no names are given besides V.Rozhdestvensky. ${ }^{16}$ Unfortunately, there seems to be a gap once more in the records of the works displayed at the shows. The artists assembled at the exhibits perfectly capture the war period and its impact on Uzbek painting. A new generation of painters being displayed alongside many of their former instructors signaled that a generational shift was beginning. This generational shift was toward the stylistic influences of the evacuated artists, whose work was changing the young painters.

\section{Cross Cultural Influences}

During the war period, and as a result of the influx of a variety of Sovietevacuated artists, a cross-pollination of culture extended beyond paintings. Artists, whether locally based or part of evacuated institutions- began exchanging ideas and influencing each other's works. During the Second World War the interactions meant that some Soviet musicians adopted Uzbek styles and techniques. ${ }^{17}$ Theatre interactions

\footnotetext{
${ }^{15}$ Doi, Gensture, Gender, Nation, 29.

${ }^{16}$ ISUz1917-1972, 176.

${ }^{17}$ Tomoff, Uzbek Music's Separate Path, 219-22.
} 
meant playwrights from other parts of the Union were producing works co-written with Uzbeks. ${ }^{18}$ Similar developments can be seen in the creation of this period's paintings. Artists, such as Shamsroi Khasanova, often recognized as the first official female painter in the Uzbek Republic, received instruction from evacuated artists including M.Shemyakin, and V. Rozhdestvensky ${ }^{19}$ Khasanova, who had been previously trained by Benkov and Volkov, incorporated elements of miniature art into her work, as she painted portraits often of famous Uzbek female poets. In the opinion of S.T. Inamova-a contemporary Chairman of the Women's Committee of Uzbekistan, the instruction given to Khasanova accounted for the "complex and contradictory development of her creativity. ${ }^{20}$ This contradictory nature can be observed in her pieces throughout the evacuation period and beyond, as she would undertake works that could be either miniature-styled or realist. Her Self portrait reflects influences from realism, but her 1947 Portrait of Matraba, Poetess of Kashgar ${ }^{21}$ completed after the war is an obvious example of contemporary miniature.

Similar to previous works such as Usto Mumin, Khasanova's paintings were not simply copies of older Central Asian miniatures; instead they "synthesized with the pictorial traditions of Paul Gauguin." 22 The result was a grouping of works which were clearly not socialist realist in design. This would cause some level of criticism in the postwar period. However, likely due to her position as Director of the Arts Museum of

\footnotetext{
${ }^{18}$ Manley, To The Tashkent Station, 221.

${ }^{19}$ Dilbar Saidova, "Pearl of the Uzbek Art - artist Shamsroi Khasanova," accessed March 5, 2011. http://www.sanat.orexca.com/eng/1-05/pearl_of_art.shtml. ${ }^{20}$ Ibid.

${ }^{21}$ The work during the de-Stalinzation period, the brief period when artists were permitted a greater degree of freedom, was displayed in Montreal in 1967. Unfortunately, she would not live to witness this success, dying in 1956.

${ }^{22}$ Dilbar Saidova, "Pearl of the Uzbek Art - artist Shamsroi Khasanova."
} 
Uzbekistan and the contradictory nature of her own work, she was able to continue painting. This could have been a reflection of limited showings of her works since despite being listed as part of the "young generation",23 of Uzbek artists I was unable to find any mention of her works being displayed at major exhibits until after her death.

Institutionally the influx of artists led to a number of changes-including efforts to "develop" the arts in the Uzbek SSR as art organizations originating outside of Uzbekistan, worked to create similar institutions to their home cities. The development was geared to replicating the styles that were currently being undertaken in cities such as Kharkov. Still, impacts would not be felt immediately. The opening of the Institute of Theatre in Tashkent in 1944 provides one such example. The Institute's opening was important to note since ten years later it would house an art school that would develop a curriculum based on the Russian academic art school model as part of a formalized teaching method that began in the post world war period. ${ }^{24}$

However, not all evacuated institutions were pleased with interactions between their previous students and the local populace. For some, such as S.G. Nevel'shtein, director of Leningrad's Repin Academy of the Arts ${ }^{25}$ changes were problematic especially when they impacted the "quality" of an institution. During a 1942 meeting of the school, based in Samarkand, he expressed this much in stating:

It is obvious that, after evacuation, our School began to lose its character as a modern school. Our staff has thinned out. The contingent of students is not what it was in Leningrad... We must reexamine all plans in order to raise the spirit of the students.... We have departed from the standards of the school by not fulfilling our

\footnotetext{
${ }^{23}$ Rashidovich, The Art of Soviet Uzbekistan, 28.

${ }^{24}$ Akbar Khakimov, "The Problem of Utopia in the XIX-XXI Centuries Art of Uzbekistan," Accessed March 5, 2011, http://sanat.orexca.com/eng/1-10/akbar_khakimov.shtml.

${ }^{25}$ The institution was also locally affiliated with a Samarkand-based school, but the above description and this discussion concerns the school that was evacuated from Leningrad.
} 
goals. There is no real creative leadership in any of our classes... The teachers must raise their qualifications and strive for membership in the Union of Artists. ${ }^{26}$

The statement echoes many of the general sentiments at the time concerning the state of arts institutions. Only thirty-five students from the Repin academy had enrolled between 1943 and $1944^{27}$ and instructors were obviously disillusioned by the quickly diminished enrollment from over one hundred. However, there is also an underlying subtext with the statement of the need to "raise qualification" of teachers in the same paragraph of losing one's character. S.G. Nevel'shtein believed that exposure to Uzbekistan had lowered the abilities of instructors at this "modern school." Samarkand had infected the instructors, lowering their ability to teach the modern socialist realism method.

Despite these remarks most comments from evacuated painters were positive and praised the Uzbeks for hospitality and generosity. According to an account by artist Grigori Ulko, as a show of thanks for the hospitality shown to evacuated artists who lived in Samarkand during the war, many gave their works to the local artists' union. ${ }^{28}$ However, the head of the local union, Benkov, did not wish to take responsibility for the expensive works. So he created a commission to provide justification for their destruction, and then set fire to them. ${ }^{29}$ The unfortunate disposal of these pieces has deprived modern researchers of a record to see if any of those artists changed their own works either in subject or style in way that would have deviated from established styles. But this systematic destruction seems to demonstrate two realities: a lack of resources similar to other periods, and the lack of interest shown for the works themselves. In terms

\footnotetext{
${ }^{26}$ Leon, Centaur: The Life and Art of Ernst Neizvestny, 37.

${ }^{27}$ Ibid., 35-37.

${ }^{28}$ Bown, "Painting in the Non-Russian republics," 152.

${ }^{29}$ Ibid., 152.
} 
of explanations as to why Benkov destroyed the works I can offer two, though it is important to note Benkov's health issues likely factored into both. During the war period his health declined significantly, a point that he acknowledged in his correspondence during and after the war. His decision to burn the works could have been due to his disagreement with their composition, possibly not in line with socialist realism: but this explanation is unsatisfying given what we know of Benkov. It is more likely, given the time he spent with the artists, that Benkov did this as a deliberate attempt to save the artists from possible persecution by Soviet bureaucrats. If their works had "strayed from the path" as the previous discussion suggests, then the burning of the works could have been a measure of protection both for him and the artists.

\section{Leaving to Fight and Paint}

Although many artists stayed in Uzbekistan during the war period, others such as Organes Tatevosayan and Ural Tansykbayev would leave to paint the war effort in different areas, returning with changed works appearing highly realistic and aligned with state expectations. Meanwhile, Bahram Hamdamn-H. Mansurov, a fellow student painter -was killed, with the consequential impact of the war being a tragic reduction in the numbers of painters, in particular the younger generation.

Tatevosayan, whose paintings in previous years had been highly criticized for their exotic nature and style, enjoyed sudden praise for his works created during the war, which served as eyewitness accounts of some of the battles. His works, according to one source, demonstrated the "bravery" of the Soviet soldier. ${ }^{30}$ Tatevosayan's war creations were significantly different from those of his previous years. Consider his previous works such as Village with its influence from miniatures. The war's works featured not only

\footnotetext{
${ }^{30} I S U z$ 1917-1972, 165.
} 
soldiers, but were of a markedly different new painting style. Though most demonstrated the reflections of a changed painter, they now looked remarkably similar to other works of the period.

Meanwhile, Tansykbayev's work in the period began to take on the landscape perspective, which he would continue to use in the 1950s and the 1960s. This style, unlike previous works which incorporated abstraction, was far more realistic in depiction and from a vastly different perspective. His series On the Roads of War consisted of fifteen works, mostly small in size and completed on canvas and cardboard. ${ }^{31}$ The materials used for the series, like the works done by other artists during the war, were completed on lower quality art supplies; as a result many did not survive. Based upon historical writing, the pieces depicted a mixture of war landscapes and captured the powerful images of the war outside of Moscow with dark grays. ${ }^{32}$ Other works which have survived from the period depicted themes of labour and production-starkly contrasted from earlier works-which ranged from stylized imagery of Uzbek life, to bold shapes and design that have been compared to Paul Gauguin's work. Although as Ginsbury's study of Tansykbayev's paintings notes:

[He] never painted power stations, factories, transmission lines or oil derricks at close range, but made then an organic part of the distant background where the antennas and derricks seems a fine cobweb etched against the sky or the foliage, and the construction sites and factories merge into a harmonious coloristic whole with the far flung expanses of the surrounding lands ${ }^{33}$

The attempts by the artist to integrate structures into the landscape suggest image construction at the time emphasized the romantic view of an unspoiled land. The reality

\footnotetext{
${ }^{31}$ Ibid., 176.

${ }^{32}$ Ibid.

${ }^{33}$ Ginsbury, Ural Tansikbayev, 5.
} 
was far from the case. In the years leading up to the war, as previously discussed, artwork portrayed a land changing and modernizing with mass industrialization in areas ranging from Fergana to Tashkent, led by the local resources of cotton, coal and oil production. I believe one way of viewing these works is to realize artists had to retreat into a safe and acceptable art form, which would not upset state censors. The retreat could also be a reaction to wartime experiences. Regardless, the result was that like many of his peers the painter was conforming to the art that was pushed by the State.

However, despite the painters' contributions, most of the works that depicted the Second World War front undertaken by Uzbek painters would not actually be painted until the mid 1960s and 1970s as historic canvases or memorialized records. A retrospective on artists of the Second World War cements this view with many of the painters who also served in the war painting works during this later period. The Tashkent exhibition was entitled The First Republic Exhibition of Works by Artists of the Great Patriotic War (1984) and claimed to be the first of its kind to incorporate a mass showing of Uzbek artists' war works. ${ }^{34}$ Most of the works displayed homecomings, but others displayed clear depictions of battlefields in Moscow. The works displayed in the catalogue were nearly all in realist style and celebrated the Soviet victory.

The legacy of the war period in Uzbek art can be summarized in two ways: first, the influence on both Uzbek and Russian painters; second, the contrast of artists' experiences to the general populace. Clearly, Uzbek painters' exposure to colleagues from other areas of the - Soviet Union whether in Tashkent or on the battlefield - was to

\footnotetext{
${ }^{34}$ Soyuz khudoznnikov Uzbekistana SSR, Pervaiia Respublikanskaia Vystavka Proizvedenii Khudoznnikov-Uchastnikov Velikoi Otechestvennoi Voiny,(Katalog), (Tashkent: Gazety Fruhzevets, 1984), n.p.
} 
have a lasting impression. It provided an opportunity for a further melding of styles, but simultaneously allowed, as the following chapter will discuss, for the future dissemination of socialist realism via painters or institutions that chose to stay in the city. As a result, a new wave of formalism emerged and the new style of post-war period of Uzbek paintings would materialize. 


\section{Chapter Seven: Zhdanov and the Anti-Cosmopolitan Campaign}

According to an untitled report following the Second World War, recovery of art and literature within the Uzbek SSR was well underway by $1951 .{ }^{1}$ Problems still plagued the Republic: an important retrospective showing of unnamed artists' works in 1947 from the Second World War had to be held in a former department store, likely due to limited space. $^{2}$ Artists were forced to share studio space and several painters fell ill because of poor living conditions. People in their twenties looked much older, wrote artist V. Urmanchi, recalling the condition of youth in the cities. ${ }^{3}$

One explanation for older looking youth might have lain in the condition of the evacuation cities, which had been overburdened. Infrastructure had been improved to handle the population inflow, but many projects had yet to be completed. ${ }^{4}$ The result was that cities like Tashkent became perfect disease incubators, with incomplete sewage pipes and unsanitary housing. ${ }^{5}$ Given these conditions it is hardly any wonder that artists, like other civilians, faced significant hardships.

However, despite these issues inundating the Republic's artistic community, the author of the previously mentioned untitled report Comrade Beria ${ }^{6}$ added that Uzbeks are increasingly embracing themes that demonstrate progress of the Soviet state and

\footnotetext{
${ }^{1}$ V. Veimarn, Izobrazitenhogo Iskusstva Uzbekskoi SSR, Zhivopis, Skulptura, Grafika, Vystavki, (IanvarFevral Iskusstva, 1952)1-11, 34. (hereafter cited as IIUz) 34.

${ }^{2}$ P.P Benkov 1879-1949 VP,171.

${ }^{3}$ Ibid., 170 .

${ }^{4}$ Ibid.

${ }^{5}$ Stronski, Tashkent: Forging A Soviet City, 148.

${ }^{6}$ The report does not state who this Comrade Beria was, although given the time period and the casual usage of the name it was likely Lavrenty Beria. Bown has noted that Beria did have influence on art during the 1930s period at least in Georgia, where a group of painters were influenced. See Bown, "Painting in the Non-Russian republics,"145. I have also found references to Beria's influence on painters in Georgia in 1935, when he was credited with playing "a big role" in art developments in the republic. See SAssr, 24.
} 
communism. ${ }^{7}$ The report notes a shift towards conforming to socialist realism that began within the post-war period in Uzbekistan and reflected an increasing level of interaction between officials in Moscow and other areas of the Union. The shift began with a movement to discredit certain existing artists, while moving to promote the "good and the best" found in patriotic and everyday themes rendered in realist styles. In the context of the developing Cold War the race to prove Soviet superiority in all spheres, including culture, became a priority. Thus the increase of interaction between Moscow and farflung regions was not limited to paintings, but represented a broader campaign within the arts as the central leadership began to exert its visible influence across the Union.

In 1945 , shortly before the end of the war, officials began revealing what would characterize the period until Stalin's death in 1953 and even beyond. B.G. Gafurov, then first secretary to the party in Tajikistan, spoke of the "backward intelligentsia" in the arts who threatened youth, thus undermining Soviet efforts in cultural activities. ${ }^{8}$ The problem, according to Gafurov, lay in the failure to recognize the need for "special preparation" in art activities. ${ }^{9}$ Gafurov's comments can characterize the general approach the Soviets would take following the end of the war. The claim of a disruption among youth by existing, older artists would be used in a number of Central Asian and other Republics to justify further involvement of Moscow and the removal of many party officials. The arts needed "special" assistance from the Soviet capital to ensure that images showcased Soviet successes to the rest of the world and art's ability to connect with every citizen.

\footnotetext{
${ }^{7}$ IIUz, 34.

${ }^{8}$ Rakowska-Harmstone, Russia and Nationalism in Central Asia, 263.

${ }^{9}$ Ibid.
} 
The appointment of A. A. Zhdanov as the chairman of the USSR and chief of cultural organizations in the Soviet Union cemented the direction arts were to follow. The period is sometimes referred as the Zhadanovschchina or Zhdanov doctrine period. According to Zhdanov, art was broken into two categories: imperial or socialist. Imperialism was to be avoided at all cost as it represented the art of capitalism, while socialist art was a mixture of everyday and patriotic themes summarized as a conflict between "best and good". Zhdanov's interpretation of art was running in conjunction with a socialist realist art campaign.

Zhdanov wanted artists' work to depict the future Soviet state. The ideal was not merely to record the present, but to make an effort to inform the public of the supposed virtues and triumphs of the Soviet system. As Zhdanov phrased it, artists had to follow the pace of change and the development of Soviet culture or else "become redundant."10

The Zhdanov doctrine prioritized Russian culture over others in the Union.

During a meeting of writers and the Party Executive in Leningrad Zhdanov declared "The best traditions of Soviet literature are the continuation of the best traditions of Russian nineteenth century literature." $" 11$ The continual idealization of Russian art would increase in the years ahead, with Zhdanov also urging writers, and by extension artists, to "sharply criticize" peers for failing to include sufficient ideological elements within their works. ${ }^{12}$ The encouragement of open criticism of other artists work allowed for the fostering of campaigns against "formalist artists" - those who believed in art for art's sake. It also

\footnotetext{
${ }^{10}$ TSK KPSS. and Andrei Zhdanov. The Central Committee Resolution and Zhdanov's Speech on the Journals Zvezda and Leningrad, Trans. Felicity Ashbee and Irina Tidmarch (Royal Oak, Mich: Strathcona Publishing, 1978), 65.

${ }^{11}$ Ibid., 63.

${ }^{12}$ Ibid., 64
} 
allowed for the creation of a new threat to the arts posed by so-called cosmopolitism artists, who allegedly supported foreign styles over Soviet ones.

The establishment of the USSR Academy of Arts in 1947 allowed for a concentrated campaign against both formalism and cosmopolitism across the union. In Uzbekistan, the artist Alexander Volkov, sensing the changing tide, abandoned his position in the Artists' Union of Uzbekistan and virtually ceased his painting - although not before writing in a journal entry "life beat me but I won't surrender. To every blow I will answer with a work of art." ${ }^{, 13}$ Volkov continued painting without official status as an artist within the Republic. The Uzbek Artist Union explained Volkov's sudden absence from exhibitions as relating to health concerns. The Union's ostracizing of Volkov was necessary as he was a constant reminder of the past art and the competencies of indigenous painters. His unwillingness to conform and acts of defiance, including quitting his position before he could be deposed, must have frustrated officials.

A museum committee in Moscow proposed sometime during the late 1940 period to "keep one of the painter's works for future reference, one for the storage room and destroy the rest." 14 The action was never carried out. Instead, like many artists of the time his work was quietly removed from inventories. ${ }^{15}$ The reported destruction had the opposite effect with many of his works carefully saved because of the presumed destruction of the rest. Following Volkov's death in 1957, after nearly ten years of criticism and ostracism, his work began to be recognized once more and he was recast as an important Uzbek artist, a reputation that has continued today.

\footnotetext{
${ }^{13}$ A. Volkov, "My zdes Tol'ko kochevinki," 47.

${ }^{14}$ Ibid.

${ }^{15}$ Ibid.
} 
Other painters who were part of 1920s artist movements were also targeted. Mikhail Kourzin, the painter who had been imprisoned in the 1930s was once more harassed. In 1946, he had returned to Uzbekistan and lived in Bukhara for two years without incident, struggling to survive. Following the cosmopolitan campaigns Kourzin was banned from Uzbekistan and sent to Krasnoyarsk for his past actions. Hence the actions of officials were not influenced by artworks, but rather past actions that artists had partaken or allegedly partaken.

\section{Creating a New Art In Uzbekistan}

In the immediate years following World War II, there was a clear process of marginalizing of specific artists and the artistic styles they represented, with selective elevation of other artists' influence. Instruction was a key element that Soviet officials were concerned with, aiming to directly change the way art was taught in order to stem potential deviations from a particular style and subject in the future. The experiences of Benkov and Volkov during this period exemplify two opposing paths of artists and the Soviet influence.

As part of the shift towards Zhdanov's doctrine in 1947, Alexander Gerasimov ${ }^{16}$ would become president of the Academy of Arts for the Soviet Union. Gerasimov was known as one of the more devout followers of Zhdanov, and was notorious throughout the Union for his aggressive tendencies and attacks against non-policy sanctioned art. He also enjoyed special favour from Stalin and is sometimes referred by art historians as "Stalin's painter". Even prior to socialist realism, the young Gerasimov criticized his peers, calling them "aesthetes" for favouring avant-garde art instead of what he

\footnotetext{
${ }^{16}$ For a complete biographical discussion of Gersaimov see Matthew Cullerne Bown, "Aleksandr Gersaimov" in Art of the Soviets: Painting, Sculpture, and Architecture in a One-Party State, 1917-1992, ed. Matthew Cullerne Bown, et al.(Manchester: Manchester University Press,1993), 122.
} 
considered to be the best art work, which was primarily Russian realism. ${ }^{17}$ Privately and perhaps contradictorily he in fact painted non-sanctioned art (nudes) from the 1930s to 1940s, but those works were never displayed publicly and little was known of their existence until after the Soviet Union's collapse. ${ }^{18}$

Similar to other artists, Gersaimov was part of the evacuation from Moscow going to Tbilisi for a brief time, explaining perhaps in part his later emphasis on art from the Central Asian and Caucasus Republics. Gerasimov articulated his stance on the arts in the Republics as needing further guidance, which, in keeping with the times, meant Russian tutelage. In his inaugural 1947 speech, he "urged artists in all the Republics to study above all the great realist heritage of Russian art." ${ }^{\prime 19}$ Gerasimov also began to take an interest in Uzbekistan and its prominent painters including Alexander Volkov - telling one of the congresses sarcastically, "look, I am almost the same age as Volkov, surely he could do at least one painting in his life" ${ }^{20}$ Clearly, Gerasimov viewed paintings outside of a realist style as pointless and Volkov's works in particular with contempt for their deviations from policy. By devaluing the works in such a direct way, Gersaimov highlighted Moscow's vision for the arts. Gerasimov's comments were as much reflections of his own beliefs of what constituted art as much as they were reflections of a lack of conformity within Volkov's work. These attacks were similar to denunciations of other artists in the Central Asian Republics by Gerasimov and were meant to illustrate that the artist's works were out of favour among the officials who defined the arts.

\footnotetext{
${ }^{17}$ Bown et al., Art of the Soviets, 123-124.

${ }^{18}$ Ibid., 176.

${ }^{19}$ Ibid., 25.

${ }^{20}$ A. Volkov, "My zdes Tol'ko kochevinki," 47.
} 
In the post-war period, the majority of criticisms launched against artists was directed against those who were most prominent, but not in compliance with the approved styles of the Soviets. The shift in approved art and artists can be traced back to the Zhdanov resolution. That resolution specifically targeted famous Soviet writers such as Anna Akmatova. Satym Ulug-Zade - chairman of the Tajikistan's Writer Union was deposed from his position during this time, ${ }^{21}$ while in Uzbekistan the country's top composers were the primary victims, most losing their positions. Volkov, as a leading artist in the Republic and teacher would logically be a potential target for eventual criticism, especially given past accusations of formalist tendencies.

If we consider that only a year prior Volkov had been honoured with the title of the "People's Painter of Uzbekistan" and had been able to display his works in the AllUnion Still Life Exhibition, the shift seems odd. Moreover, it highlights the speed with which censors could suddenly change their views of an artist. Although it is true Volkov had been accused of formalism in the past, it is a drastic change from a respected artist to one singled out as an example of a painter who was without merit. This suggests the influence one or two officials could bring to bear on any single artist. The implications of this being that a high-ranking Soviet bureaucrat's or artist personal views on art could at times trump actual art policies or positions in the Soviet Union. Moreover, it demonstrated the importance that Volkov held within the Uzbek art scene and provides insight as to why he was targeted.

Alexander Gerasimov's attacks against Uzbek painters continued in keeping with the repressions of other artists during the time. In fact he made a rare journey to

\footnotetext{
${ }^{21}$ Rakowska-Harmstone, Russia and Nationalism in Central Asia, 256-257.
} 
Uzbekistan with the expressed purpose to "establish order" in the country. ${ }^{22}$ His arrival and vocal denouncements frightened artists who had been associated with Volkov, including Mikhail Kalontarov. Kalontarov, a former student of Volkov, went so far as to burn all of his works out of fear of reprisals. ${ }^{23}$ His works are no longer accessible as a result, thereby leaving no record of how Uzbek art may have been developing that so concerned Gerasimov.

Another significant official, Boris Veiman, was also vocal in this period; in a speech on the Tasks of the Soviet Visual art of the National Republics he told the group that:

In some republics Transcaucasia and Central Asia there is a widely-held idea that the national particularity of the Soviet art of the Eastern peoples consists of decorativism... But decorativism as a method is formalist and has nothing in common with the tasks of Soviet art. Decorativism does not allow Soviet actuality to be correctly represented in art. ${ }^{24}$

Veiman's fixation on decorativism and formalism is important. Until now, many Uzbek works were landscapes, scenes of everyday life, and some depicting the socialist realism aims. Although it was true that artists such as Volkov had experimented with other artistic forms, he, like many other artists in the country, had abandoned those styles at the same time as most painters in the Union. However, the need to draw upon decorative patterns or images fit perfectly into the image construction of the region. It also reinforced the notion that modernization was not fully completed and that more work was needed to transform art into a Soviet form, thereby justifying renewed attempts to create socialist works to exemplify the Soviet reality.

\footnotetext{
${ }^{22}$ A. Volkov, "My zdes Tol'ko kochevinki," 47.

${ }^{23}$ Ibid., 47.

${ }^{24}$ Bown et al.. Art of the Soviets, 149.
} 
These comments paralleled Soviet attempts to reinforce the idea of a shared history between the Russians and the Central Asians and Russia's seemingly inevitable role in cultural development. In Tillett's analysis, Soviet historians writing at the time tended to emphasize cultural ties within the "Soviet family" finding connections between the peoples of the region. ${ }^{25}$ Ancient Khorezm, a publication that won a Stalin prize, went further - arguing Central Asian art had been interrupted by invasions by Persian, Arab and Turkish influence. ${ }^{26}$ Historiography, just like paintings, needed to note the recent progress that had been made under the leadership of the Russian people. ${ }^{27}$

As a result of the increased scrutiny and Soviet belief of a need for Russian leadership, artists such as national artist (painter) R. Akhmedov, who had been schooled in Leningrad, began arriving in Uzbekistan to teach what some authors such as Khakimov refer to as "formal instruction," bringing with them what can be deemed as a second wave of direct teaching in styles and subject. ${ }^{28}$ The developments, Gerasimov declared, were part of a long waited "dream" of formalized teaching methods, which if possible would have resulted in the creation of manuals for everything from painting to songs. ${ }^{29}$

However, despite the push for uniform instruction, the Soviets were never able to carry out the goal of a mass publication of manuals, which even Gerasimov admitted was simply not possible. ${ }^{30}$ The publication of books on Uzbek artists seemed challenging enough for the Soviets to achieve. One film-maker would state, recalling an art exhibit in Uzbekistan during the era, that books on Uzbek painters were scarce if they existed at

\footnotetext{
${ }^{25}$ Lowell Tillett, The Great Friendship: Soviet Historians On The Non-Russian Nationalities, (Chapel Hill: University of North Carolina Press, 1969), 100.

${ }^{26}$ Ibid., 104.

${ }^{27}$ Ibid., 86.

${ }^{28}$ Khakimov, Art Education in Uzbekistan, 182.

${ }^{29}$ Sessii Akademii Khudozhestv, 8.

${ }^{30}$ Ibid.
} 
all. ${ }^{31}$ The film-maker recalled people simply remembered works from the exhibitions. ${ }^{32}$ The books that were published with instruction often encountered major delays. An Uzbek dance manual depicting dance styles was written in 1965 , but failed to reach publication until $1973 .^{33}$

Despite the shortcomings, the formalization wave continued with instructors relying upon Russian works as the guiding force. However, unlike their predecessors such as Benkov, these painters did not encourage students to create their own works. Existing instructors were also encouraged to fall in line with the new shift. In a letter written sometime in 1949 Benkov references a notice he received as a member of the Committee of the All-Union Exhibition in 1949, that all instructors needed to be acquainted with the government's orders and training within Uzbekistan. ${ }^{34}$ Benkov requested further information on the training and orders, but would not receive them until after his death later that year. The referenced letter circulated to committee members highlights the efforts that Soviet officials were making to ensure a uniform level of instruction in key learning institutions. Instructors, whether existing or arriving, were to teach the same styles thus ensuring graduating students would be conforming to the new style and subject.

The indoctrination into a specific form of accepted artwork seems to extend further than merely within higher education. The Soviets feared the potential influence of older generations on the youth even as late as 1949. Gerasimov warned of the dangers

\footnotetext{
${ }^{31}$ Ural Tansykbaev: Vospominaniia, 36.

32 Ibid.

${ }^{33}$ Doi, Gesture, Gender, Nation, 80.

${ }^{34}$ P.P Benkov 1879-1949 VP, 212.
} 
that faced youth, who might be corrupted by adult formalist painters. ${ }^{35}$ Children, it was believed, needed to receive early instruction to ensure their paintings were not outside of the prescribed ideal in the future.

The result was that as early as 1947 , programs were designed to ensure that artistic talent could be molded from a young age. In a Moscow News report published in September 1947 there was the mention of a large children's exhibition in Tashkent where "thousands of drawings, paintings and technical models by children" were displayed. ${ }^{36}$ The article also describes that most of the drawings sent to this exhibition were "chiefly those made by children outside school hours in drawing circles which function at schools in children's clubs. ${ }^{937}$ However, even for youngsters, the influence of policy expectations can be noted in the article's statement that works "exhibited conception of the swift industrial development that has taken place during Soviet times in Uzbekistan."38 Although the article does not give specifics as to the industrial elements featured it can be assumed that the standard imagery of cotton fields and road construction appeared in their artwork.

The direct instruction would also guard against Gerasimov's fear of influence of formalist painters, who he explained in a speech "most dangerously maim and corrupt our artistic youth by knocking them off the right path of service to the nation." 39 In targeting the youth the Soviets evidently hoped to create a generation that not only avoided

\footnotetext{
${ }^{35}$ SAssr, 7.

${ }^{36}$ Coates, W. P. (William Peyton), and Zelda K. Coates. Soviets in Central Asia. (London: Lawrence, 1951), 269.

${ }^{37}$ Ibid., 270.

${ }^{38}$ Ibid.

${ }^{39}$ SAssr, 7.
} 
"corruption" by past instructors, but would be on the "correct" path of serving the state by reinforcing positive imagery.

In her study on Uzbek dance, Doi notes that at roughly the same period children also became the targets of recruitment into dance schools. ${ }^{40}$ Orphanages were seen as recruitment centres, freeing instructors to teach what they wished. The proliferation of younger children into dance reflected the belief that age was linked to dance, with only young women being selected to perform in the public sphere. ${ }^{41}$ It also reflected an attempt to ensure loyalty to the state at a younger age by showing the benefits it could provide. The increased ability to define dance became an important development that paralleled developments in visual arts.

If we recall the two 1940 exhibits and the ability to define art, then references to ceramics and wood carving as folk art point to an important example of that continued influence. The artworks were to take on a Russian definition of visual arts.

As the previously mentioned newspaper notes:

The folk-art of the people is clearly seen in the section given over to creative efforts in ceramics and wood-carving. There are fanciful jugs, teapots, bowls and dishes sent by the school children of Rishtan, Kitab and Tashkent, and lovely caskets with stylized caring and mosaic work from Khiva. ${ }^{42}$

The description of "fanciful" ceramics underscores the way the Soviets viewed art forms that did not promote the state themes of industrialization. They were simply not as important. Obviously, as folk art, unlike the previously mentioned paintings they did not present imagery of "swift industrial development".

\footnotetext{
${ }^{40}$ Doi, Gensture, Gender, Nation, 78-81.

${ }^{41}$ Ibid., 79.

${ }^{42}$ Croat and Croat, Soviets in Central Asia, 271.
} 
Besides new instructors and instructive techniques, new artistic supplies and materials also began to flow into the Republics. ${ }^{43}$ In November 1948, new equipment for poster creation-including paper and new printing equipment began arriving in the country. ${ }^{44}$ These new technologies were developed during the mass printing campaigns of the Second World War, while the Uzbeks were still using out-dated equipment. ${ }^{45}$ A year later, during an anniversary celebration of Uzbekistan supported by the Union of Soviet Artists of Uzbekistan, it was claimed in a historical review of the events (by the artists union) that poster art had finally improved with the help of the new equipment. ${ }^{46}$ Thus, "art" was something that could potentially be corrected through the upgrading of technologies and equipment, although the primary method for achieving Soviet aims remained instruction.

Prior to his death, Benkov was replaced by Zinaida Kovalevskaya as the Samarkand school's head teacher. Kovalevskaya, being a former student of Benkov, produced work that was remarkably similar to her former teacher, mainly realist. ${ }^{47}$ Officials, who increasingly encouraged the realist method, appointed her to guarantee that the leadership at such an important institution would promote this method.

If there had been any doubt that the realist techniques of Benkov were the Sovietendorsed art form, then the campaign of promotion for the artist following his death dispels it. Benkov's contributions were quickly elevated after his death. The Academy of the Arts stated that he contributed to the instruction and development of painting in the country, and it helped to rename the Samarkand school and a street in Samarkand after

\footnotetext{
${ }^{43}$ ISUz 1917-1972, 256.

${ }^{44}$ Ibid., 133-134.

${ }^{45}$ Ibid., 134.

${ }^{46}$ Ibid., 133-134.

${ }^{47}$ P.P Benkov 1879-1949 VP, 146.
} 
him. ${ }^{48}$ During Benkov's memorial service, artists of all media and from across the Republic paid tribute to the painter, with many recollections from colleagues published in an official document about his life several years later. Local newspapers, including the Leninist Path, highlighted the great contributions noting that "a memorial plaque was placed at his house." ${ }^{49}$ A honourary retrospective was also held.

The death of Benkov and marginalization of Volkov meant paintings in Uzbekistan were truly moving in a different direction. New instructors and teaching styles were taking the place of the two instructors and painters who had disproportionately dominated the previous three decades. The changes in paintings would parallel those in other art forms. In 1951, composers would arrive to further reinforce European models of music in the Republic, ${ }^{50}$ while dance at the time would take on further Russian influence-with many of the instructors staying in Uzbekistan after the evacuation..$^{51}$ The reintroduction of Russian and European art instruction marked an important turning point, since it not only confirmed that Uzbek art, until then, had been on an incorrect path, but also reinforced the idea that only Soviet-styled, formalized instruction could produce a successful artist.

\section{Greater Standardization of Works}

As the Second World War drew to a close and the Zhdanov doctrine period began I have noted a change in how artists in the Uzbek SSR represented facial features. Prior to this period most people's faces were left blank, in a profile position or with only the limited facial features regardless of the painter. The immediate postwar period, however,

\footnotetext{
48 I. Iras, Redaktor-Sostavitel', Khudoznniki Sovetskogo Uzbekistana, (Tashkent: gosudarstvennoe izdatel'stvo khudozhestvennoi literatury uzbekskoi SSR, 1959), 120.

${ }^{49}$ P.P Benkov 1879-1949 VP, 206.

${ }^{50}$ Tomoff, Uzbek Music's Separate Path, 234-235.

${ }^{51}$ Doi, Gesture, Gender, Nation, 72.
} 
witnesses an increasing level of facial detail. This observation to my knowledge has never been noted either in the USSR or by contemporary authors.

First, to be clear about the significance, this change does not seem to be momentous in other areas of the Soviet Union, where people's faces in state-sanctioned paintings had been clearly depicted since the end of the avant-garde movement in the 1930 s. ${ }^{52}$

The time span of works that display these limited facial features was concentrated in the 1920s and 1930s, although works display this phenomenon up until the Second World War. For example, Tansybayev's work Wrestling (1929), one of his early paintings, serves as an example, with people's faces left blank. His work Crimson Autumn to a lesser extent demonstrates this phenomenon, as well with its limited features. More concretely, Benkov's works at times showed blank faces of people in otherwise clear depictions, with his early works from the early 1920s including Ashhana in Bukhara (undated) displaying this fact. Limited facial features can also be found in the works of Kashina prior to the Second World War; Children is a good example with a family practically faceless.

Recalling the general definition of formalism, the art critic Kemonov's comments on "distorting the face" raises the question whether paintings in Uzbekistan up until the outbreak of the Second World War could be viewed as formalist. The issue is that they also incorporated elements of the desires of the State that advanced its own agenda via depictions of successful Soviet policies.

\footnotetext{
${ }^{52}$ Bown, Bulanova and Rosenfield do not observe any transformation in Soviet paintings during these periods.
} 
I conclude that the increased sharpness in facial features in the postwar era was a response at least in part to changes encouraged by officials. However, this does not fully account for the shift since this trend can be observed, throughout the Second World War itself. What made the war years different from the previous eight years? Evacuated citizens and increased interactions amongst artists were the main difference. This conclusion is important because it adds a new dimension to the notion of the Second World War period as a defining event in the country.

One of the major paintings of the late 1940s that highlights the changes in Uzbek art is Lunch-time by Nadezhda Vasilyevna Kashina, dated 1949. Kashina, arrived in Samarkand at the same time as Benkov and other artists in 1928. Born in Perm and studying at the Vkhutemas- a state art and technical school located in Moscow - under P. Falk and S. Gerasimov, her earlier works were abstract depictions of Uzbekistan. These pieces were in many ways similar to Benkov in capturing a slightly more idealized view of the country. Prior to the Second World War Kashina painted limited facial details in her paintings, but gradually placed more emphasis on features.

"Lunch-Time" represents a clear departure from those earlier pieces, with highly detailed faces of the three women in the foreground. The smiling women look to be having a lively debate, with a copy of a document in one of their hands. In many ways, the painting is the realized fulfillment of the idealized teahouse imagined by earlier Soviets. As previously discussed, teahouses were seen as important proper locations for male Uzbeks to socialize and discuss ideology. The appearances of a newspaper and unveiled women connect with the previous literacy as well as the unveiling campaigns and demonstrate a Soviet "success." The painting, as an added assurance to connect the 
accomplishments to the state, even includes a USSR button worn by the woman in the center. The painting, despite its obvious attempts to appeal to socialist realism tenets was nonetheless criticized in an art magazine review for its "invented" colours. ${ }^{53}$ It can be assumed recalling past criticisms of colour that the issue was due to its perceived "sugary nature" in other words its exceedingly bright colours which did not reflect "reality." The criticism of colouring is odd given the magazine was printed outside of Uzbekistan with the authors likely never having ventured into the Republic. The continued criticism of largely complying paintings was enormous. It meant that paintings began to be selected for exhibition on a haphazard basis, with older paintings sometimes displayed in lieu of new ones.

The Soviets began seeking out older works that displayed imagery of the "friendship of the nationalities" and other themes. The painter Tatevosyan Organes Karapetovich's piece Reception of Stalin at Collective Farm, completed in 1935, provides the perfect example of older painting selection and was exhibited in the 1950 All-Union Art Exhibition. The painting depicted smiling people surrounding Stalin, complete with Uzbeks wearing "national dress" and presenting cotton to Stalin. ${ }^{54}$ The work was hailed as an ideal painting and a great accomplishment giving the impression that the work had been recently created. The reason the Soviets chose to use older pieces was that later pieces did not always contain the same highly political messages. For example, Tatevosyan had started drawing still life in the late 1940s and early 1950s and teaching at the Institute of Theatre in Tashkent, established in 1944. His newer works of still life were not political, nor did they praise the regime. These newer less political

\footnotetext{
${ }^{53} \mathrm{IIUz}, 40$.

${ }^{54}$ Ibid., 36.
} 
works could have been a reflection of trauma experienced during the Second World War or else a retreat into a safer genre.

By the beginning of 1952, an article appearing in the Soviet magazine "art" declared the defeat of the "rootless cosmopolitan" arts. ${ }^{55}$ The article explained how the great achievement was possible through the guiding force of Stalin, and marginalizes Zhdanov. It fails to mention the lack of guidance given to artists during the war period and the role that key officials besides Stalin played in transforming the art world. This is problematic since it gives the false impression of an uninfluenced change of artistic works leaving the responsibility solely on the artists for the changed works. In the subsequent chapter I will demonstrate how the changes that took place during the late 1940s would fundamentally change the way painters undertook art within Uzbekistan. Even after the thaw period and a reinterpretation of socialist realism began in other parts of the Union following Khrushchev's de-Stalinization speech, paintings in Uzbekistan seem to have remained on the same path as the late 1940s. Art, as the article predicted would "develop"- that is to say; develop into a standardized method even faster in the coming years

\footnotetext{
${ }^{55} \mathrm{IIUz}, 35$.
} 


\section{Chapter Eight: The Thaw}

After Stalin's death in 1953 and Khrushchev's ascent to power, the Soviet Union underwent what is often referred to by historians as "the thaw" period. In 1959, Sharif Rashidov- a novelist and former head of the writers union who had become supreme chairman of the Uzbek SSR- told attendees at the Second Congress of Uzbekistan's Intelligentsia that the practices carried out from 1920 to the 1950s damaged Uzbek culture. ${ }^{1}$ During his address Rashidov noted a number of problems including the referral of Medieval Central Asian writings by Soviet officials as "mystical and anti-popular."2

At the same address Rashidov would conclude by stating that that the intelligentsia:

must possess the best qualities of the leading workers and farmers: proletarian purposefulness and persistence principled in ideas. Selfless devotion to party and Motherland, limitless loyalty to the ideas of Marxism-Leninism, as with all strength must fight for the purity and complete triumph of socialist ideology ${ }^{3}$

The comments nicely summarized the 1953-1960 "thaw" era, capturing the contradiction of finding a balance between the denunciations of the previous thirty years while maintaining links to the previous period's goals. In the Uzbek SSR, this meant continuing depictions of reality through the use of popular images of industrialization and maintaining the "purity" of the socialist project by censorship.

\footnotetext{
${ }^{1}$ Allworth, The Modern Uzbeks, 256.

${ }^{2}$ Ibid., 256

${ }^{3}$ Ibid., 257
} 


\section{Changing Directions Before Stalin's Death}

Even before Stalin's death evidence can be found for the easing of restrictions on art. ${ }^{4}$ G. M. Malenkov, premier of the CPSU, told the nineteenth party congress in 1952 that a reinterpretation of socialist realism was needed. He declared art "must boldly portray life's contradictions and conflicts...employ the weapon of criticism as a means of education. ${ }^{.5}$ As the researcher Arthur Voyce notes, the departure from the previous socialist realism interpretation meant artists were to be permitted greater latitude since now creators would be permitted to "portray life's contradictions," something previously not permitted. ${ }^{6}$ However, the party would maintain most of the elements of the old system, cultivating a common sense of purpose within art. This meant the visual arts would need to continue to depict images of a positive system that included these new elements.

Despite the events transpiring in Moscow, within Central Asia paintings showed few, signs of change in during the early 1950s. Officials continued to complain, even in the 1950s of the problems with paintings in the Central Asian Republics. At the Seventh Congress of the Central Committee of Tajikistan (1952) officials argued that culture had not developed in the Republic because of a lack of party leadership. ${ }^{7}$ Although Soviet officials were satisfied that industrial development had occurred in the Republic, cultural development needed further guidance. Thus while the "developed areas" (mainly Russia)

\footnotetext{
${ }^{4}$ Arthur Voyce, "Soviet Art and Architecture: Recent Developments", Annals of the American Academy of Political and Social Science, Vol. 303, Russia Since Stalin: Old Trends and New Problems (Jan., 1956), 114. 5 Ibid.

${ }^{6}$ Ibid.

${ }^{7}$ Rakowska-Harmstone, Russia and Nationalism in Central Asia, 220-221.
} 
were permitted a greater level of artistic freedom, the areas on the periphery needed continue guidance.

In Uzbekistan, this meant a continued promotion of realist artists from abroad or else increased influence from painters who had been schooled in the realist method. Benkov's former student Kovalevskaya continued as the head of the Samarkand school, now named after her former teacher. She would be joined by other former pupils of Benkov, including the Abdullaev brothers and much later R. Timurov (a previously littleknown painter) who served as instructors both in Samarkand and in Tashkent alongside the instructors who arrived in the Republic from Moscow and Leningrad during the anticosmopolitan campaigns.

Benkov's former students, painting in a realist fashion, dominated exhibits with works appearing in exhibits in Tashkent, Samarkand and even Moscow. The paintings exhibited were mainly portraits. For S.F Abdullaev, who had earned the title, "Hero of the Soviet Union" for "heroism in battle with the invaders," his paintings exemplified these new works, as he concentrated on famous Uzbek artisans and officials. ${ }^{8}$

In his painting In the Studio of Master Usman Zufarov, Abduallaev depicts the master Uzbek musician playing a dutar [a type of lute specifically from the Central Asia region, which has two strings and is meant to be plucked] with a small audience listening intently. The painting, in a realist style, bears a resemblance to many of the paintings of the 1920s with the positioning of the musician, in a similar fashion to undertakings by his former teacher Benkov. The relationship suggests in many ways a return to the earlier realist depictions, the change being that the works were no longer conducted by artists who were from abroad, but who were born and schooled within the region. The

\footnotetext{
${ }^{8} \mathrm{IIUz}, 35$.
} 
implication of this was that the Soviets had successfully achieved, in this younger generation, painters who were undertaking works that more closely aligned with state desires.

Another painter, V. Fadeev, rose to prominence during the period with styles consistent with realism. Fadeev's works were described at the time as taking on themes of famous artisans as well as the promotion of simple, non-threatening subjects. The painting $A$ Guard, completed in the latter part of the 1950s, depicts many of the same elements of $19^{\text {th }}$ century paintings. The painting features an elderly woman sitting on a box with a rifle leaning on one shoulder, while she holds a bowl of tea. The work was described by the Artists' Union as providing an image of the new national identity without ethnographic or exotic elements. ${ }^{9}$ It was seen as a depiction of the "new Soviet woman"10 and was displayed prominently as a result at a 1959 exhibition of Uzbek art in Moscow. The work removes any visual indications of specific place identification, although the displaying of the bowl was included as a definite connection to Central Asia.

Abdulhak Abdullaev (brother of L. Addullaev), another one of Benkov's top students, also generated similar portraits to S.F Abdullaev (no relation) almost exclusively of the intelligentsia in Uzbekistan starting in the mid 1940s. His most famous works during the 1940s included a depiction of A. Hidoyatov (Fig.11), an actor who had performed as Othello in a production billed at the National Uzbek Theater in Tashkent. The painter would later write:

I was very keen to present this great talent and thus express my humble recognition of it.... When Hidoyatov agreed to sit for the portrait as Othello, we were given a make-up room next to the stage. Usually, before starting a portrait, an artist is looking for a characteristic posture, an interesting turn, a typical gaze

${ }^{9} I S U z 1917-1972,170$.

${ }^{10}$ Ibid. 
of the one whose portrait he is going to paint. But Hidoyatov was so impressive in that character that there was no need to look for anything ${ }^{11}$

The artwork displayed features not dissimilar to classical Russian works. The choice of Abdullaev to embark on a portrait of a character from a European play as opposed to a character of one of the Uzbek plays, was telling of the artist's priorities. In fact, almost all of his series of portraits of theatre actors (1940-1950) are from performances of European plays. The "great talent," and Abdullaev's recognition of it, was predicated upon whether or not they performed in Euro-Russian plays.

During this period-in particular in Tashkent, the Soviets began to promote the idea of a new cultural city that could serve as a "model" for future areas both inside and outside of the Soviet Union. ${ }^{12}$ The official descriptions Soviets put forward to tourists in particular was the idea of a dual Uzbek and Russian culture. ${ }^{13}$ However, in reality, the culture that was promoted was one with heightened European elements. ${ }^{14}$ The painting of A. Hidoyatov with its dual layers of meaning is fascinating, since not only did it display the desired European styles, it also displayed a European subject, which meant it conformed to Soviet expectations on multiple levels. In painting portraits of select performances Abdullaev was giving credence to Soviet aims at the time on this multitier level.

\section{Art After Stalin's Death}

Following Khrushchev's rise to power the Soviet Union began de-Stalinization. Artists were to be given greater freedom in their expression and styles. An official

\footnotetext{
11“Abulkhak Adbukkaev "Of Human Beauty," excerpt from book titled "Craving for the Beautiful" published in 1994 by Abulkhak Adbukkaev," Accessed March 5, 2011, http://www.sanat.orexca.com/eng/3-09/abdulkhak_abdullaev.shtml.

${ }^{12}$ Stronski, Tashkent: Forging A Soviet City, 245.

${ }^{13}$ Ibid.,245.

${ }^{14}$ Ibid.,244.
} 
communiqué from the $20^{\text {th }}$ Party congress, the same in which Khrushchev would give his "secret speech", states:

Creative work in art and literature must be permeated with the spirit of struggle for communism, it must instill courage in people's hearts and firm conviction in their minds, it must cultivate a social mentality and a comradely sense of duty. ${ }^{15}$

Artists were to create art work that would depict a struggle for communism, while at the same time they were permitted to show social commentary or even paint in styles previously shunned. This meant, similar to Malenkov's comments during the $19^{\text {th }}$ Congress, that art works were no longer required to capture merely an idealized reality, but could also display challenges within the Soviet system. Although a departure from past reprisals faced under the Zhadanov period it seems the system was to undergo a slow process of change throughout the early $1950 \mathrm{~s}$.

Khrushchev would speak in one of his speeches in 1957 of the great contributions of the Russians and the need to recognize the "culture backwardness" and oppression of non-Russians prior to the helping hand of Russian involvement. ${ }^{16}$ In evaluating the various speeches by Khrushchev a renewed understanding of the arts can be found, but most of the speeches that give specific directions as to the undertakings of the arts appear only in the very late 1950s and early 1960s. Khrushchev was certain that the Stalinist period had produced poor quality art works, but seemed unsure or unwilling to describe the new direction that was needed before consolidating his leadership. The impact on the arts was clear within the cities of Moscow and Leningrad.

As art historians Maria Bulanova and Dr. Alla Rosenfield write:

\footnotetext{
${ }^{15}$ N.S. Khrushchev, The Great Mission of Literature and Art, (Moscow: Progress Publishers, 1964), 11.

${ }^{16}$ Ibid., 21.
} 
The partial liberation of society initiated by Krushchev helped unleash the concealed creative potential of a number of Soviet artists, prompting many to produce works of their own that challenged the tenets of Socialist realism. At the same time artists had to pursue alternative types of venues at which to display these works: private apartments and a range of public spaces, including clubs, scientific research institutes, cafes, and lobbies of movies theatres. ${ }^{17}$

The de-Stalinization efforts meant that specific artists and critics were out of favor. Alexsandr Gerasimov, who still led the Academy of Arts, was marginalized almost immediately after Khrushchev's secret speech, along with a number of other painters who openly criticized their peers during Stalin's reign. Khrushchev would rebuke Gerasimov semi-privately in 1957 after the artist questioned the wisdom of abandoning the previously-established form of sanctioned paintings. Gerasimov resigned the following day at the urging of colleagues and after nearly dying from a heart attack the night before due to heavy drinking. ${ }^{18}$

In Uzbekistan, the changes of the late 1950s eventually revealed a returning to previous merging of styles discussed. Kashina, the previously-discussed painter of Lunch Time painted A Small Skull Cap in 1960. The piece once more shows signs of breaking with the canon of socialist realism. Its usage of both shape and design suggests a modest return to the pieces undertaken by artists in the 1930s. However, Kashina's piece generally represents an exception rather than an example of the period suggesting that artworks may have been on a trajectory of changing once more in the 1960 s.

\section{Lasting Legacy}

Besides former pupils the few living painters from the previous generation who had shifted styles reached their height of political power. In 1956, Ural Tansykbaev, the

\footnotetext{
${ }^{17}$ Bulanova and Rosenfield, Soviet Disunion, 24.

${ }^{18}$ For a complete description see Bown's account of the evening as described in an interview with Gerasimov's son. Bown, "Painting in the Non-Russian republics,"138-139.
} 
same painter who had once done the painting Crimson Autumn, became the chairman of the board of Uzbek SSR Union of Artists, serving until 1959. The painting Collective Landscape by Ural Tansykbaev-also completed during this period - provides one sample of the lasting impact of the socialist realism project on the previous generation. The painting, as the title would suggest, features a collective farm with people gathering cotton. Its appearance in a high realism style was comparable to most of the works from the late 1940s and once more reflected the cotton production theme. During this period the Soviet government yet again emphasized cotton production with new irrigation lines being built. The painting, given its size, leaves the impression of a limitless cotton supply, but in reality the supplies of cotton had until this period had been problematic.

The painting also serves to construct labour relations within the Soviet Union. Cotton picking was a labour-intense excessive, which involved both women and children. Most paintings concerning cotton including Collective Landscape, (Fig.11) depict only women; however children do not appear. This was likely deliberate in order to minimize a mixed message of children labouring and education promotion among the same youth. The result was the association within paintings of older women with the cultivation of the "white gold".

The irony of creating an ideal that did not represent the reality was not lost on painters from the period. Even as Tansykbaev created works that largely praised the regime such as his Collective Landscape, he was aware of the artificial construction of works and persona. He once jokingly relayed a story of when he traveled with film maker M.A. Kayumov who was doing a documentary of his work. During a point in the film Tansykbaev is seen fishing, but as he later explained the entire scene was staged. The fish 
Tansykbaev was shown to have caught were purchased from local fisherman and hooked onto the line to make it seem as if Tansykbaev had caught them. ${ }^{19}$ Kayumov told Tansykbaev at the time that the fabrication was justified because the hero (Tansykbaev) could not be seen without a fish. ${ }^{20}$ The "great realist film maker" Tansykbaev reportedly laughed when he told the story, years later. ${ }^{21}$ Tansykbaev's story was likely told with a degree of sarcasm signaling that he understood the differences between reality and staged displays and the parallels faced by all artists in producing work that fit the official presentation of the arts.

Tansykbaev would also participate in the important All-Union Agricultural Exhibition, constructing the Uzbek pavilion alongside several Russian painters from Uzbekistan in $1952^{22}$. For reasons unknown other Uzbek painters did not participate. The need to draw upon Russian painters to fill the membership of Uzbekistan was not unique to the Central Asian Republic. At the Inter-Republican Show of the Artists of Central Asia and Kazakhstan in 1955, of the 18 painters representing Tajikistan only 5 had "Tadjik names"- two of whom had only recently begun to show their works. ${ }^{23}$ The marginalization of Uzbeks from official functions could be a reflection of the general trend and as added assurance that the Uzbek "model" attempting to be exported to other countries would be maintained. Since the Soviets still had reservations about the quality of Uzbek works, drawing upon Russian painters may have been seen as a way of counterbalancing those fears.

${ }^{19}$ Ural Tansykbaev: Vospominaniia, 42.

${ }^{20}$ Ibid.

${ }^{21}$ Ibid.

${ }^{22}$ Akhmedova, U. Tansykbaev:Selected works, n.p.

${ }^{23}$ Rakowska-Harmstone, Russia and Nationalism in Central Asia, 138. 
Tansykbaev's work would once more gain international recognition in 1958 winning both at a Belgium exhibition and the Brussels Expo. Morning at the Karakum Hydroelectric Plant was described as a major feat- when it took silver in Brussels. In correspondence from Moscow Tansykbaev was praised for the awards. One letter from Army General Petrov concerning the Brussels exhibit congratulated him for showing the "superiority" of Soviet over modern capitalist art. ${ }^{24}$ The Army General went on to explain how the artist had captured the beauty of nature in Uzbekistan. He finishes with a comment about the great role that Tansykbaev played in the development of Uzbek paintings over the years. The General's statements were telling of the kind of developed paintings the Soviets had envisioned for the period.

Overall, the period of 1953-1959 reveals that the Soviets continued to desire artworks that were premised upon socialist realism within Uzbekistan. Despite the ability of painters in other areas of the Union to experiment the artists living in Uzbekistan continued painting in the previously prescribed styles. The leadership promoted Russian works in the Republic, while claiming the obviously more European form was a blended style between Russian and Uzbek. The younger generation largely continued to follow the encouraged styles, with dissent that characterized the past decades now minimal to non-existent.

${ }^{24}$ Ural Tansykbaev: Vospominaniia, 147. 


\section{Conclusions}

Since the 1994 exhibit Agitation for Happiness, exposure to paintings from the Stalinist period has continued. Besides exhibits, artistic forms such as theatre and film have broadened people's knowledge of the period. In 2006, the Ilkhom Theatre - a theatre troop based in Tashkent- toured Germany with its production Usto Mumin. The play charts the life of Usto Mumin and literally displays an impressive array of documents relating to the artist's life. ${ }^{1}$ In addition to the play about the noted Uzbek artist, a documentary film entitled The Forbidden Desert has also been produced, which concentrates on the Nukus Gallery. The documentary charts the history and efforts to preserve art works from the late Soviet period to the present. It has been screened around the world, and has won several international film festival awards.

The result of these new productions has been increased knowledge of the period and increased interest from outside Uzbekistan. It is that increased interest in the art works that likely contributed to the seizure of many of the paintings and the closure of the Nukus museum nearly a year after I had visited the collection. According to the official narrative at the time it was in preparation for a new museum building, but no such building has begun as of the time of writing. Unofficially, as the New York Times recently reported, its closure was the result of state officials fearing the level of contact museum staff had with people abroad. ${ }^{2}$

\footnotetext{
1“"About", Accessed December 23, 2010, http://www.ilkhom.com/english/theatre/

${ }^{2}$ Ellen Barry “'Decadent' Russian Art, Still Under the Boot's Shadow," Accessed March 9, 2011, Updated March 7, 2011,http://www.nytimes.com/2011/03/08/arts/design/desert-of-forbidden-art-igor-savitsky collection-in-nukus.html.
} 
In many ways current events repeat the Socialist Realist period, only now targeting the institutions rather than the artists themselves. In the post Soviet period, the museum had enjoyed widespread support from the government. A large picture of President Islam Karimov inaugurating its opening was on display at the entrance of the museum when I visited in the fall of 2009. The drastic change from praise and support for the museum to closure echoes past experiences of artists discussed throughout this study. Hence the current events underway at the museum affirm the relevance of this study to the present day.

\section{Review}

In our discussion of the period before the 1930s, miniatures are shown as having combined many elements from Persia, China, Europe and Russia; in fact it has been demonstrated that the works from their inception were a combination of various methods and styles. As the $19^{\text {th }}$ century drew to a close those miniatures were undergoing further changes, declining in numbers and transferring to different mediums, such as wall panels. These developments coincided with the introduction of new instruction in stylistic techniques, as the two main Russian ideas: avant-garde and realism were introduced into the region. The result was a new blended style of Russian and indigenous works constituting a third form. Distance from Moscow and limited number of artists meant that in contrast to other locations and artistic groups, painters often interacted with each other despite disagreements over some of the art works. The variations that were apparent in the early part of the $20^{\text {th }}$ century would slowly disappear over the next two decades, as the Soviets asserted control 
The interactions between Moscow and Tashkent would only truly begin to take shape in the late 1930s. The early 1930s was characterized by a lag in policy enforcement allowing painters to continue to display their works despite a policy that directly challenged their existence. The display of certain works and the arrests of some artists meant limitations in paintings, but there were always exceptions. Volkov's arguments that some paintings undertaken during the period were in fact part of the Uzbek culture allowed their painters to elude censors for that period. If we consider that Tansykbaev was able to continue to paint miniature artworks as late as 1940 without facing reprisals, it seems that the appeal to paint on the basis of nationality was an effective strategy. However, if painters undertook this direction their works were less likely to be displayed, as the 1940 exhibition experience highlights. The exhibit also provided an important guidance to defining the arts relegating miniature art as non-compliant art.

The Second World War period proved to be a relatively relaxed interlude when officials likely cared more about winning the war than enforcing cultural policy, especially in an area so far away from Moscow or Leningrad. Artists from Uzbekistan were encouraged to document the war. Some took up this challenge, with several not returning from the front, while others struggled to maintain themselves in the cities of the Republic. The experiences between artists and ordinary citizens in Uzbekistan's cities revealed a split in wartime experience, with a promotion of art continuing despite hardships faced by evacuees. The interactions with artists from other areas of the Union produced a lasting impact, sowing the seeds for many of the changes in direction that would take place in the post-war period. It also demonstrated the influence contact with other artists had on the arts rather than policy. Artists who returned from fighting were 
similarly impacted producing works that resembled their counterparts in other areas of the Union during the time. These findings directly contradict Bown's conclusion that the war period had "limited impact."3

Stronger censorship would reappear in the post world war period Zhdanov's doctrine of culture and art developed, running parallel to the goals of socialist realism. Volkov became a primary target causing wider implications for art in the Republic, namely shifting it further away from experimentation. However, this period was also notable for a clear shift in how art was undertaken in the Republic, with a greater emphasis on instruction in European styles impacting students both at the secondary and post secondary levels. The fear that existed over the power previous artists had on youth is most revealing and demonstrates the importance of artistic instruction for the Soviets.

The Khrushchev period highlighted the extent of the impact of the events from the Second World War period. The paintings during the six-year span from 1953 to 1959 were largely unchanged from the trajectory that had been established during the Second World War. As other areas of the Union experienced greater levels of liberation, the works in Uzbekistan were relegated to maintaining the previous socialist realist project. The Soviets promoted the idea that the new artworks were now officially a combination of Uzbek and Euro-Russian culture, while unofficially they were principally Europeanized undertakings. The need to display the success led some painters-notably Abdullaev-to undertake works that highlighted the Euro-Russian element. The awarding of important international prizes to painters such as Tansykbaev solidified in the minds of officials that their "development" goals had been realized.

\footnotetext{
${ }^{3}$ Bown, "Painting in the Non-Russian republics,"148.
} 


\section{Implications}

This study has also revealed several points of interest, the first that socialist realism policy does not seem to be the only determining factor in the outcomes of paintings for the period. Throughout the study it is revealed that the impact on works was subject to much broader events taking place in the Republic. This includes the role of émigrés and the subsequent interactions between artists in generating artworks. Many of the more noted painters from Uzbekistan - such as the national artists including Pavel Benkov, Tatevosyan Organes and Aleksandr Nikolaev/Utso Mumin - were born elsewhere before coming to Uzbekistan in the early 1920-1930s and then making it their home. They served as the instructors in many of the prominent schools of the time, introducing Western or more often Russian styles into the country. However, they were not merely the transmitters of culture, but also receivers, the most extreme case being of Nikolaev changing his name to Utso Mumin and converting to Islam. Along with Tatevosyan, Usto Mumin undertook works that melded miniature styles with his previous European training. The result of the experimentation undertaken by Utso Mumin was a brief incarceration in Moscow.

The creation of blended styles was not limited to émigrés, as the painters from the region also undertook works that combined styles. These blended works slowed during the push towards socialist realism, but never truly stopped until after the Second World War. Even then we can note the emergence of painters such as Khasanova. Her work completed in the late 1940s clearly does not correspond to socialist realism, yet she continued to paint. Given these observations the study raises serious questions as to the effectiveness of the enforcement of socialist realist policy. Although policy did clearly 
change or cause the removal of some painters, the notion of an absolute policy does not match the evidence.

Still, the impacts of those policies are important. Volkov was targeted by authorities and forced to relinquish his role in the Artist Union, while Tansykbaev's early works that were compared to great European works were completely dropped, forcing him to move into a landscape genre. The leaders of the various organizations, such as Benkov in his role as the Union head in Samarkand or Alexander Gerasimov as president of the Academy of Arts for the whole of the Union, played major roles in defining the artworks and in the process creating policy. Benkov's destruction of wartime artworks helped to define the period by those works that survived. Meanwhile, Gerasimov further defined the movement by the marginalization of certain painters and the support of direct instruction. His statements of concern for the youth of the period helped to define the education of youngsters during the 1940s, as instruction attempted to steer them back on the correct path. The formation of the policy and its subsequent application therefore was not concentrated completely in any one source - it was reliant on a series of contributing factors.

As a result, the arts and cultural program within Uzbekistan became an evolving idea, rife with contradictions, which did not have a clear set of steadfast rules. This meant each artist, exhibition and official was able to define what socialist realist meant. The evidence of this can be found mainly in the early period best exemplified in particular in the Uzbek case by the art critic Chepelev's evaluation of socialist realism. His emphasis on clarity of meaning within artists' works points to a completely different way of interpreting socialist realism. Similarly, Volkov was able to place his works into a 
different interpretation allowing for his continued experimentation. His efforts would be very effective up until the anti-cosmopolitan campaign, with a Moscow artist (Gerasimov) almost single-handedly causing the artist's downfall. The shifts between praise and criticism provide further evidence of this evolving idea.

The result of this evolving policy was the contradictory applications of it. In the 1930s, the Soviets evidently could not decide how to organize their priorities. This contradictory application of policy is illustrated by the choice to fund trips to go Moscow, while providing inadequate space for artists in the republics. The issues with application of the socialist realism ideal meant some works were criticized even when they met most if not all the requirements. The 1940s era work discussed by Kashina, Lunch-Time, provides a sample of this contradiction as well. Its display of elements that were supportive of the regime were downplayed in its evaluation instead the work was criticized for its unrealistic colouring. Kashina's later work A Small Skull Cap completed in 1960 demonstrates how radically a painter's work could change in the period. It would be an interesting case to examine if other works in the 1960s also changed back to hybrid works. It is my opinion that they likely did.

Overall, it appears within the time frame examined that the paintings from 19301960 underwent complex changes and interactions often producing unintended outcomes. The earlier decade and a half in particular demonstrate this fact most pointedly. The latter half of the 1940s demonstrates increasingly that artworks were corresponding with expectations of policy. But also, showed signs of limitations even up until and including 1960. 


\section{Bibliography}

Adams, Laura Lee, Celebrating independence: Arts, institutions, and identity in Uzbekistan. Ph.D. diss., University of California, Berkeley, 1999.

Adams, Laura L. "Modernity, Post colonialism, and Theatrical Form in Uzbekistan." Slavic Review 64.2 (2005): 333-54.

Alexander Djumaev. "Musical Heritage and National Identity in Uzbekistan." Ethnomusicology Forum 14.2 (November 2005): 165.

Allworth A. Edward. Central Asia, 130 years of Russian dominance: A historical overview. Durkam, Duke University Press, 1994.

Allworth A. Edward. The Modern Uzbeks: Form the Fourteenth Century to the Present : A Cultural History. Stanford, California: Hoover Institution Press, 1990.

Akhmedova Nigora, U. Tansykbaev : Selected works - Introductory section. Moscow, Sovetsky Khudozhnik Publications, 1989.

Appiah Kwame Anthony. Cosmopolitanism: Ethics in a World of Strangers. New York: W.W. Norton, 2006.

Belëiìaev, Viktor Mikhaæilovich. Central Asian Music: Essays in the History of the Music of the Peoples of the U.S.S.R. 1st ed. ed. Middletown, Conn: Wesleyan University Press, 1975.

Bown, Matthew Cullerne, and Brandon Taylor. Art of the Soviets: Painting, Sculpture, and Architecture in a One-Party State, 1917-1992. Manchester: Manchester University Press, 1993.

Bulanova Maria and Rosenfield Alla. Soviet Disunion: Socialist Realist \& Nonconformist Art. Minneapolis, MN: Museum of Russian Art, 2006.

Chen Jack. Soviet Art and Artists. London: Pilot Publishing, 1944.

Clark, Katerina, et al. Soviet Culture and Power : A History in Documents : 1917-1953. New Haven: Yale University Press, 2007.

Coates, W. P. (William Peyton) and Zelda K. Coates. Soviets in Central Asia. London: Lawrence, 1951.

Critchlow James. Nationalism in Uzbekistan. Boulder, Colorado, USA: Westview Press, Inc, 1991. 3-218.

Current digest of the Soviet press., et al. Current Soviet Policies; the Documentary Record of the Communist Party Congress. New York: Praeger., 1952. 
Djumaev, Alexander. "Power Structures, Culture Policy, and Traditional Music in Soviet Central Asia." Yearbook for Traditional Music 25, Musical Processes in Asia and Oceania (1993): 43-50.

Doi Masayo Mary. Gesture, Gender, Nation: Dance and Social Change in Uzbekistan. Westport, CT, USA: Bergin \& Garvey, 2002.

Eremi R.V, Kazakova L A; Musina, N K Nikolayev A.V. Tashkent: Gafur Gulayam Fiction and Art publishing House 1982.

Fitzpatrick Shelia. The Cultural Front. Cornell University Press, Ithaca and London, 1992.

Getty, J. A. A. Origins of the Great Purges: The Soviet Communist Party reconsidered, 1933-1938. Cambridge [Cambridgeshire]; New York: Cambridge University Press. 1985.

Ginsbury Isabella. Ural Tansikbayev. Aura Publishers, Leningrad 1977.

Gorky, Maxim ,Karl Radek, Nikolai Bukarin, Andrey Zhdanov and Others. Soviet Writer's Congress 1934: The Debate on Socialist Realism and Modernism in the Soviet Union. London: Lawrence and Wishard, 1977.

Gregor Gallery. The Volkov Dynasty. Washington, Gregor Gallery, 1997.

Hakimov Akbar. $20^{\text {th }}$ Century Avantguard from the Collection of the State museum of Arts of the Republic of Karakalpakstan. Tashkent, Ministry of Cultural Affairs Republic of Uzbekistan, 2003.

Hall, Stuart, "Encoding and decoding" in S.Hall, D.Dobson, A.Lowe and P.Willis (ed), Culture, Media, Language. London: Hutchingson, 1984.

Hanks Reuel. World Bibligraphical Series Volume 218 Uzbekistan. Oxford, England: ABC-Clio Ltd., 1999.

Ismailova E.M, Oriental Miniatures of Abu Raihon. Beruni Institute, Tashkent, 1980.

Kamp, Marianne. "Pilgrimage and Performance: Uzbek Women and the Imagining of Uzbekistan in the 1920s." International journal of Middle East studies Vol 34.2 (2000): p. 263-78.

Karomatov, F. M., I. Radjaboy, and Theodore Levin. "Introduction to the Šašmaqam." Asian Music 13.1 (1981): 97-118. 
Khakimov, Akbar "Art Education in Uzbekistan" in L. Joubert (ed.) Educating in the Arts - The Asian Experience: Twenty-Four Essays. Dordrecht, the Netherlands: Springer Science + Business Media B.V, 2008. 182.

Khomutova, ML. Painting and Drawing of Uzbekistan Arts \& the Islamic. World no33 68-73 Aut '98.

Khrushchev, Nikita Sergeevich. The Great Mission of Literature and Art. Moscow: Progress Pub, 1964.

------ Summary of the Speeches Made at the Writer's Meeting in the C.C. C.P.S.U. on May 13,1957 at the Reception for Writers, Painters, Sculptors and Composers on May 19, 1957 and at the Party Action in July 1957.

Krader, Barbara. "Recent Achievements in Soviet Ethnomusicology, with Remarks on Russian Terminology." Yearbook for Traditional Music 22 (1990): 1-16.

Leon Albert. Centaur: The life and art of Ernst Neizvestny. Roman and Littlefield Publishers, Maryland, 2002.

Lillys, William, Robert Reiff, and Emel Esin. Oriental Miniatures; Persian, Indian, Turkish. Rutland, Vt: C.E. Tuttle Co., 1965.

Ljunggren, David. "Art show dusts off works used to paint over Stalinism's cracks." Reuters News, April 24 1994, Section Unknown, Final Edition.

Manely, Rebecca. To The Tashkent Station: Evacuation and Survivial in the Soviet Union at War, Ithaca and London: Cornell University Press, 2009.

Martin, F. R. (Fredrik Robert). The Miniature Painting and Painters of Persia, India and Turkey from the 8th to the 18th Century. New Delhi: B. R. Publishing., 1985-1912.

Martin Terry. The Affirmative Action Empire: Nations and Nationalism in the Soviet Union, 1923-1939, Ithaca and London: Cornell University Press, 2001.

McFadyen David. Russian Culture in Uzbekistan: One Language in the Middle of Nowhere. New York, NY: Routledge, 2006.

Meisel, James Hans, and Edward S. Kozera Materials for the Study of the Soviet System: State and Party Constitutions, Laws, Decrees, Decisions, and Official Statements of the Leaders, in Translation, 2d, rev. and enl. ed. Ann Arbor, Mich: G. Wahr Pub. Co, 1953.

Olcott, Anthony, Martha Brill Olcott , and Lubomyr Hajda. The Soviet Multinational State: Readings and Documents. Armonk, N.Y: M.E. Sharpe, 1990. 
Rakowska-Harmstone, Teresa. Russia and Nationalism in Central Asia; the Case of Tadzhikistan. Baltimore: Johns Hopkins Press, 1970.

Reid, Susan E. "All Stalin's Women: Gender and Power in Soviet Art of the 1930s." Slavic Review 57 no. 1 (1998): 133-73.

Robinson, B. W. (Basil William). Persian Drawings from the 14th through the 19th Century. New York: Shorewood Publishers, 1965.

Sahadeo, Jeff. Russian Colonial Society in Tashkent : 1865-1923. Bloomington: Indiana University Press. 2007.

Said W. Edward. Orientalism, Patheon Books, New York, 1978.

Shay, Anthony(2008) "Choreographing Hypermasculinity in Egypt, Iran, and Uzbekistan." Dance Chronicle 31:2,211-238

Stronski Paul. Tashkent Forging A Soviet City 1930-1966, Pittsburg: University of Pittsburgh Press, 2010.

Tillett, Lowell.The Great Friendship; Soviet Historians on the Non-Russian nationalities. Chapel Hill: University of North Carolina Press, 1969.

Tomoff Kiril Uzbek Music's Separate Path: Interpreting “Anticosmopolitanism"in Stalinist Central Asia, 1949-52 The Russian Review 63 (April 2004): 212-40.

TSK KPSS and Andrei Zhdanov. The Central Committee Resolution and Zhdanov's Speech on the Journals Zvezda and Leningrad, Trans. Felicity Ashbee and Irina Tidmarch. Bilingual ed. Royal Oak, Mich: Strathcona Pub. Co, 1978.

Umarov Adulakh Rashidovich. The Art of Soviet Uzbekistan. Leningrad: Aurora Art Publishers, 1972.

Voyce Arthur. Soviet Art and Architecture: Recent Developments. Annals of the American Academy of Political and Social Science, Vol. 303, Russia Since Stalin: Old Trends and New Problems (Jan, 1956).

\section{Online sources}

"About." Accessed December 23, 2010, http://www.ilkhom.com/english/theatre.html.

Abulkhak Adbukkaev. "Of Human Beauty, "Except from book titled "Craving for the Beautiful" published in 1994 by Abulkhak Adbukkaev." Accessed March 5, 2011, http://www.sanat.orexca.com/eng/3-09/abdulkhak_abdullaev.shtml. 
Dilbar Saidova."Pearl of the Uzbek Art - artist Shamsroi Khasanova." Accessed March 5,2011. http://www.sanat.orexca.com/eng/1-05/pearl_of_art.shtml.

Ellen Barry "'Decadent' Russian Art, Still Under the Boot's Shadow." Accessed March 9, 201 1, Updated March 7, 2011. http://www.nytimes.com/2011/03/08/arts/design/desertof-forbidden-art-igor-savitsky collection-in-nukus.html.

"Masters of New East" in global artistic process." Accessed August 12, 2010. http://www.sanat.orexca.com/eng/3-4-05/master.shtml.

Nigora Kultasheva. "The Art of Bahrom Hamdami." Accessed August 12, 2010. http://www.sanat.orexca.com/eng/3-09/nigora_kultasheva.shtml.

\section{Sources in Russian}

Abdurazakova S.H. Kommunisticheskaeiia Partiia Uzbekistana i Rabota Sredi Zhehshchin Respubliki, 1938-1958 god: Sbornik Dokumentov i Materialov. Tashkent: Uzbekistan, 1982.

Iskusstvo Sovetskogo Uzbekistana 1917-1972, Moscow: Sovetskii khudozhnik,1976.

Iskusstvo Sovetskogo Uzbekistana, Tashkent: Nauchno-issledovatelskii institut iskusstvoznaniia UzSSR, 1957.

Iras. I, Redaktor-Sostavitel, Khudoznniki Sovetskogo Uzbekistana, Tashkent: gosudarstvennoe izdatel'stvo khdozhestvennoi literatury uzbekskoi SSR, 1959.

Mastera iskusstv Uzbekistana Karaxan, Tashkent: literaturyi isksussteva imeniga furliiama, 1978.

Miunts M.V. Axmedova H.R. Glazkova H.I.. Tansykbaev E.I.A, Ural Tansykbaev Vospominaiia Dokumenmy, Tashkent: Gafura Guliiama, 1988.

Muminova, I.M. Uzbekskoi SSR, Tashkent: Ihstitut Istorii, 1974.

Oganes Tatevosyan, Tashkent: Sovetskii Khudozhnik ,1977.

Pygrachenhova G.A. and Raximova Zi, Sredneaziatskie Miniatiura, Tashkent: Glavnaia redaktsiia zhtsiklopedii, Gafura Guliama, 1987.

Sessii Akademii Khudozhestv SSR Tretiia, Sessiia Voprosy Teorii i Kritiki, Sovetskogo Izobrazitelnogo Iskusstvo, 24 Ianvarl-Fevral 1949, Moscow: Izdatelstvo Akademii Khudoznestv, 1949. 
Soyuz Khudozhnikov Uzbekistana UzSSR, Pervaiia Respublikanskaiia Vystavka Proizvedenii Khudoznnikov-Uchastnikov Velikoi Otechestvennoi Voiny, Katalog, Tashkent: Gazety Frunzevets, 1984.

Soyuz Khudozhnikov Uzbekistana, P.P Benkov 1879-1949 Vospominaniia Perepiska, Tashkent: Gafura Guliama, 1981.

Soyuz Khudozhnikov SSR, Ministerstvo Kultury Uzbekskoi SSR, P.P. Benkov 18791949, Katalog, Moscow: Soyuz Khudozhnikov Uzbekskoi SSR sentral'nyi dom Rabotnikov Iskusstv, 1961.

Veimarn.V, Istoriia Iskusstvo Narodov SSR Vol 8, Moscow: izobrazitelnoe iskusstvo, 1977.

Veimarn.V, "Vystavki Izobrazitel'nogo Iskusstva Uzbekskoi SSR, Zhivopis, Skulptura, Grafika", Iskusstva, 1-11 (Ianvar-Fevral, 1952). 


\section{Plates}

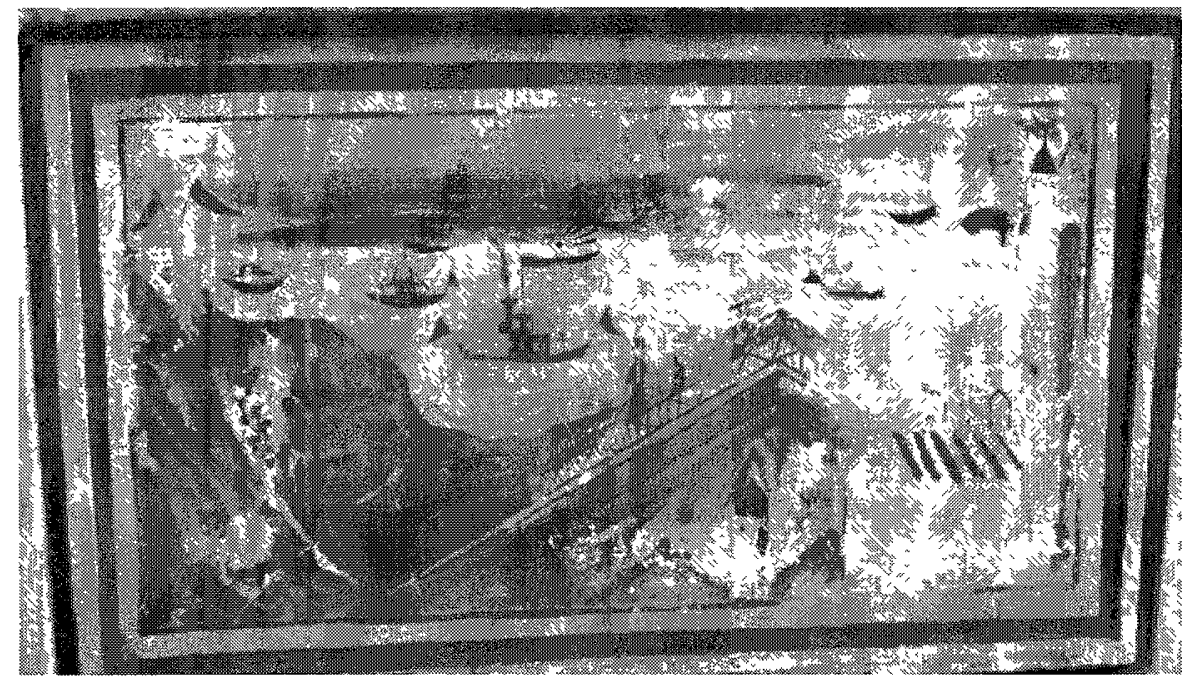

Figure 1 Untitled, Panel, gouache, Late 19th century to 20th

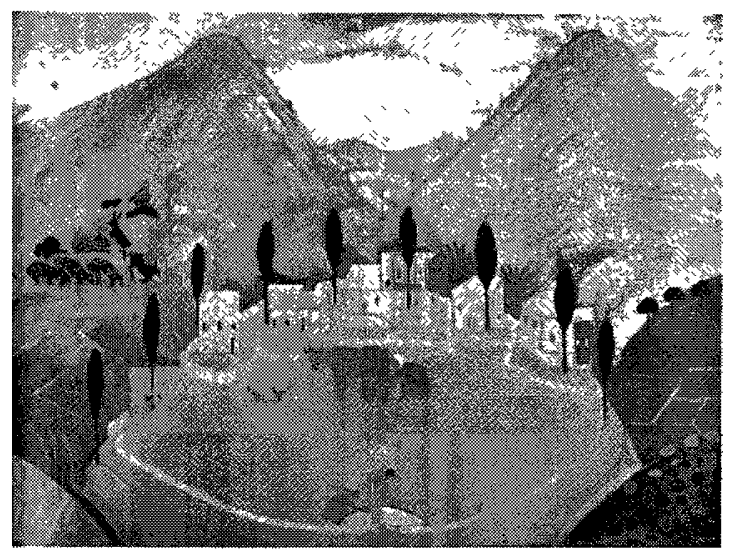

Figure 2 Tatevosyan Oragnes Karapetovich, material unknown, Village, 1919 


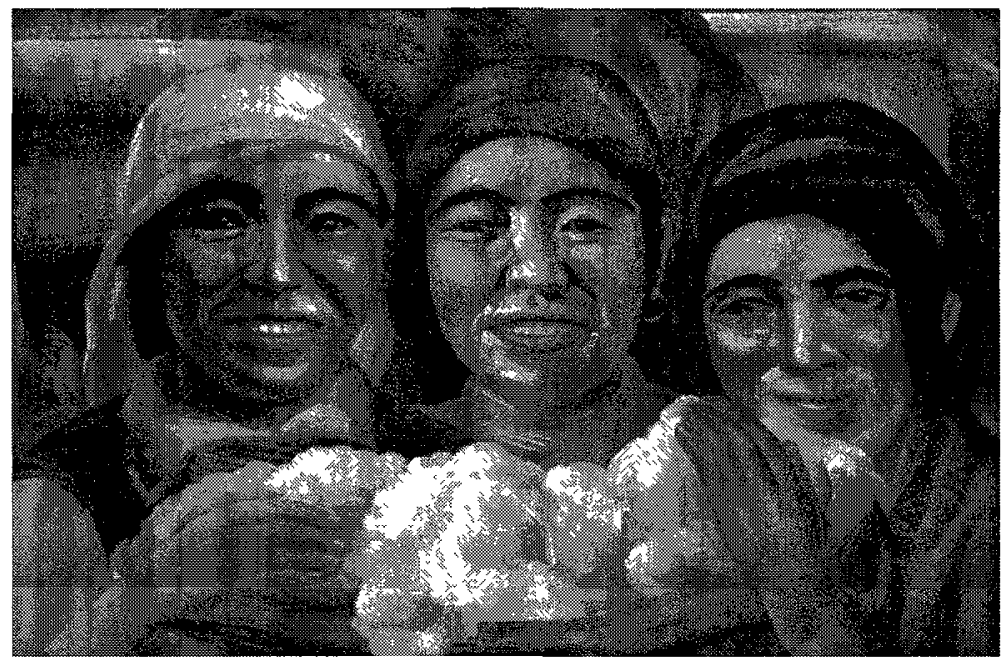

Figure 3 A Volkov, Cotton Girls, oil on canvas, 1939-1940

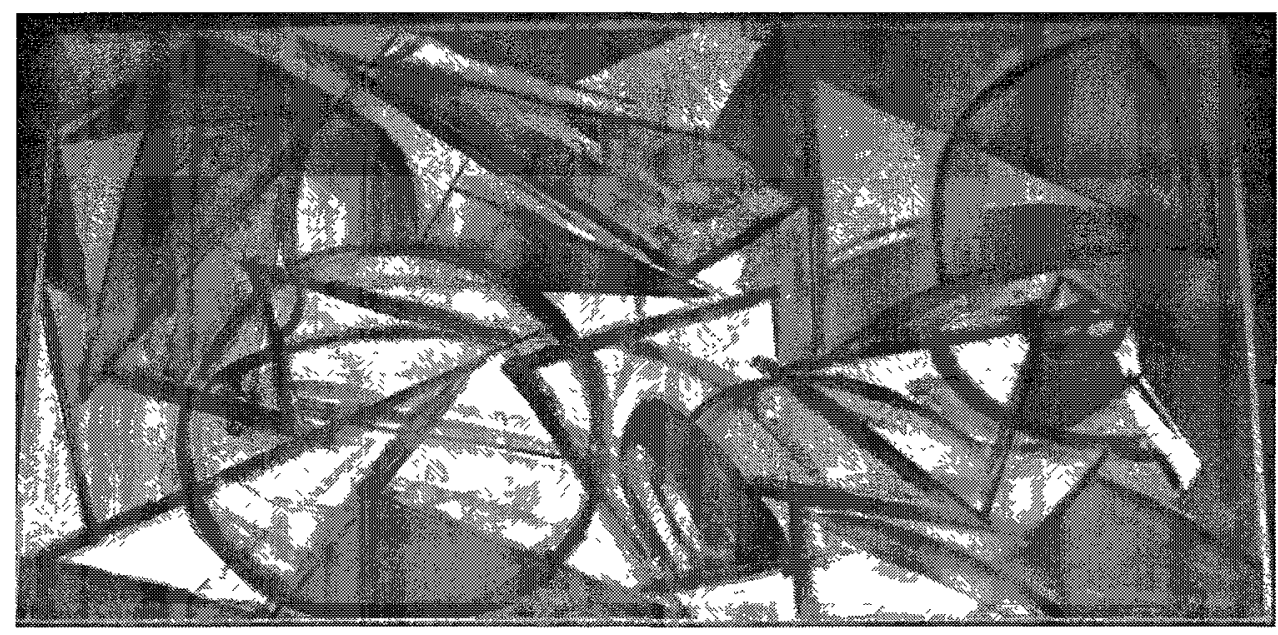

Figure 4 A Volkov. Artba (Uzbek Cart), watercolour on paper, 1919 


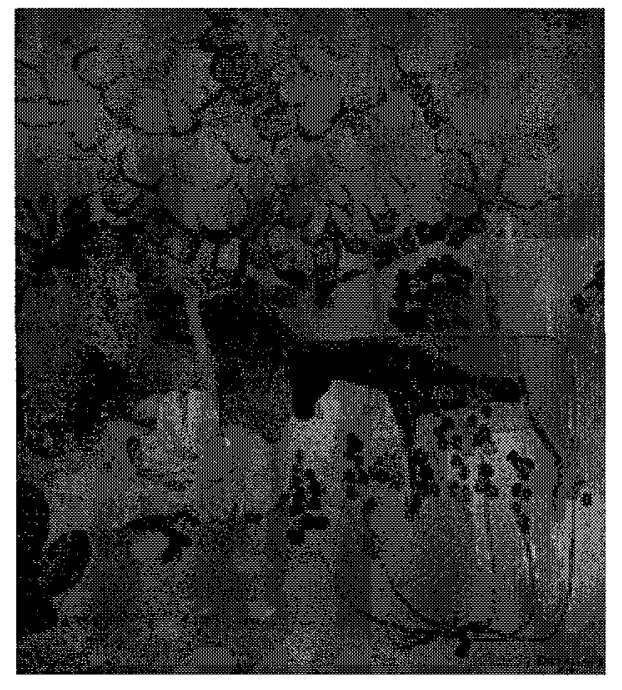

Figure 5 Ural Tansikbayev, Crimson Autumn, oil on canvas, 1931

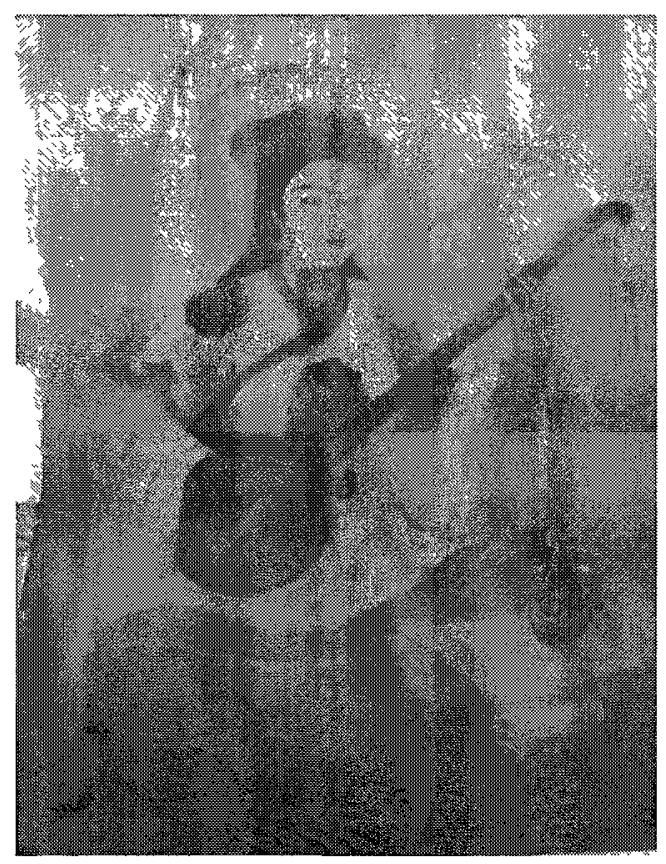

Figure 6 Shamsroi Khasanova, Portrait of Matraba, Poetess of Kashgar, canvas Distemper, 1947 


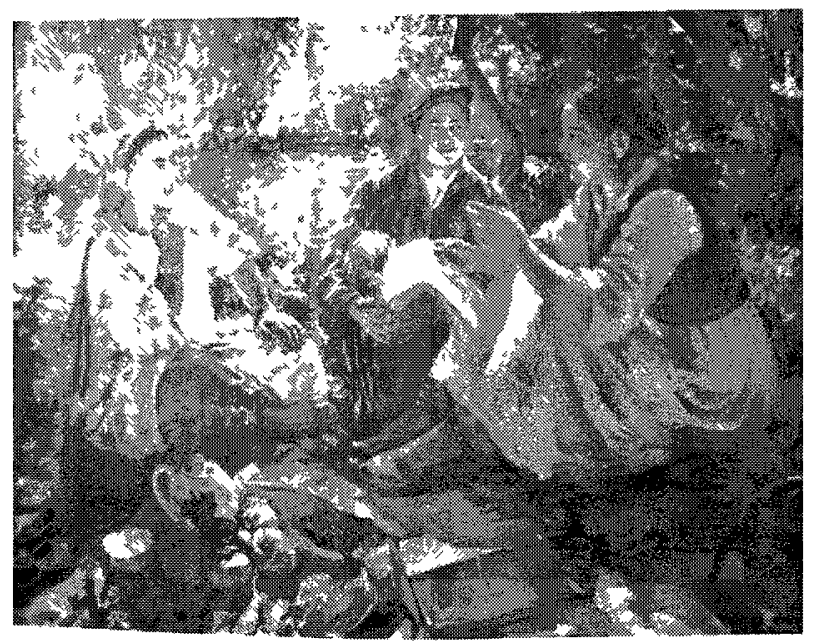

Figure 7 N.V. Kashina, Lunch-time, oil on canvas, 1949

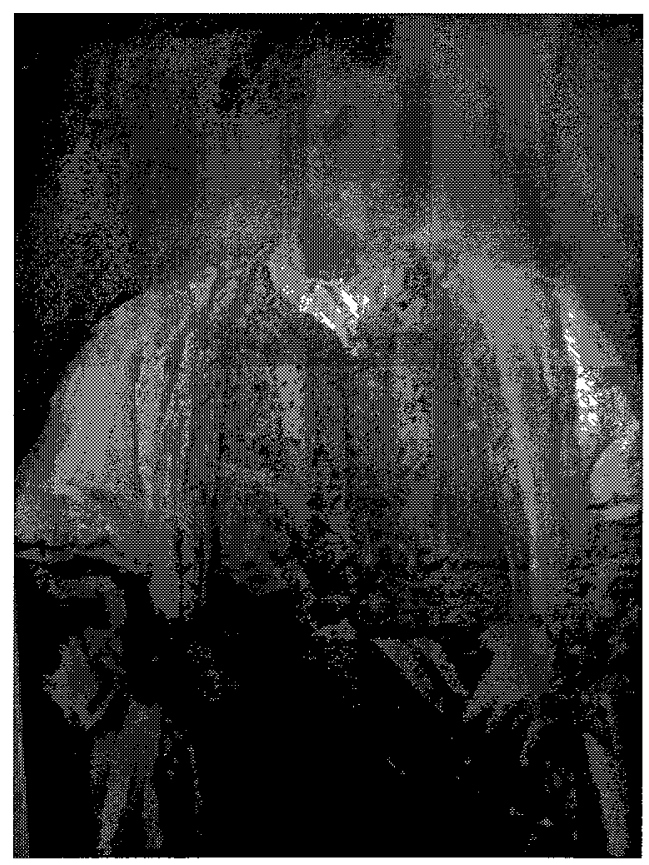

Figure 6 Abdulhak Abdullaev, A. Hidoyatov, in the Part of Othello, oil on canvas, 1946 


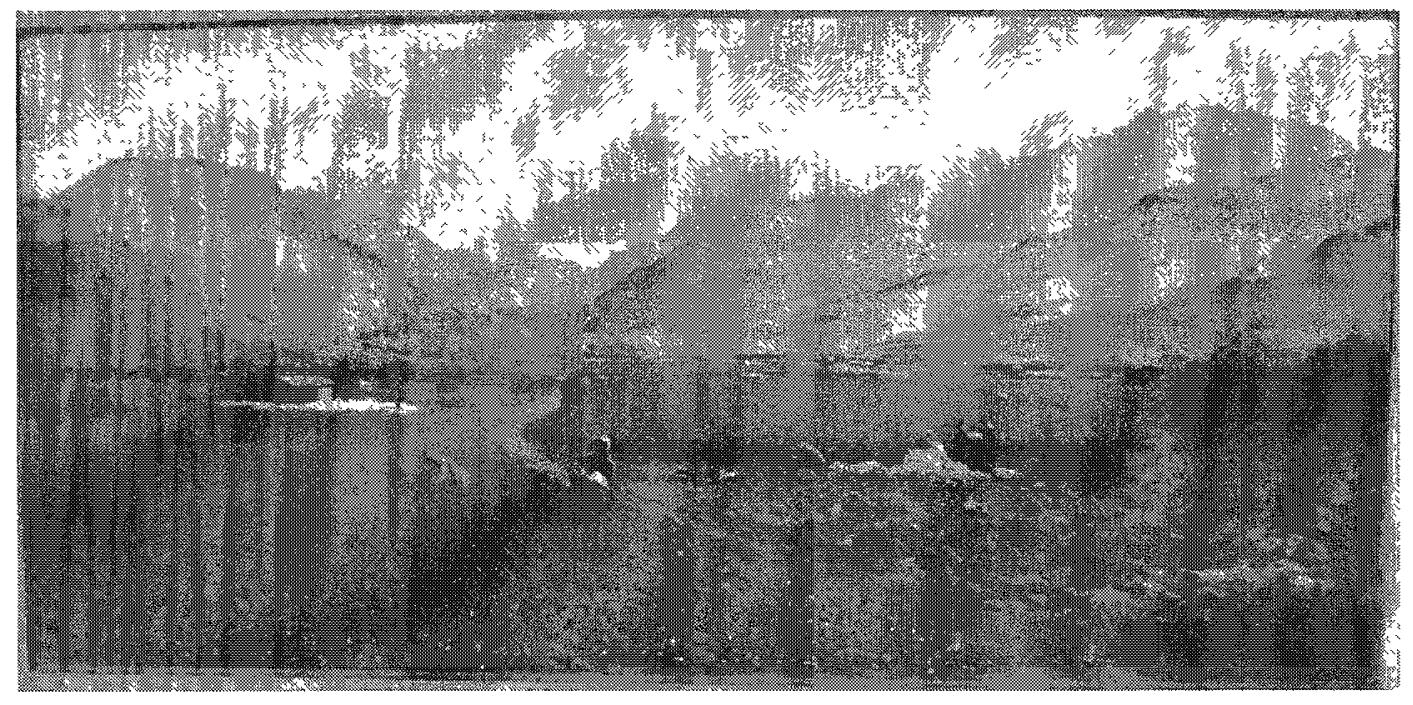

Figure 7 Ural Tansikbayev, Collective Farmscape, oil on canvas, 1958

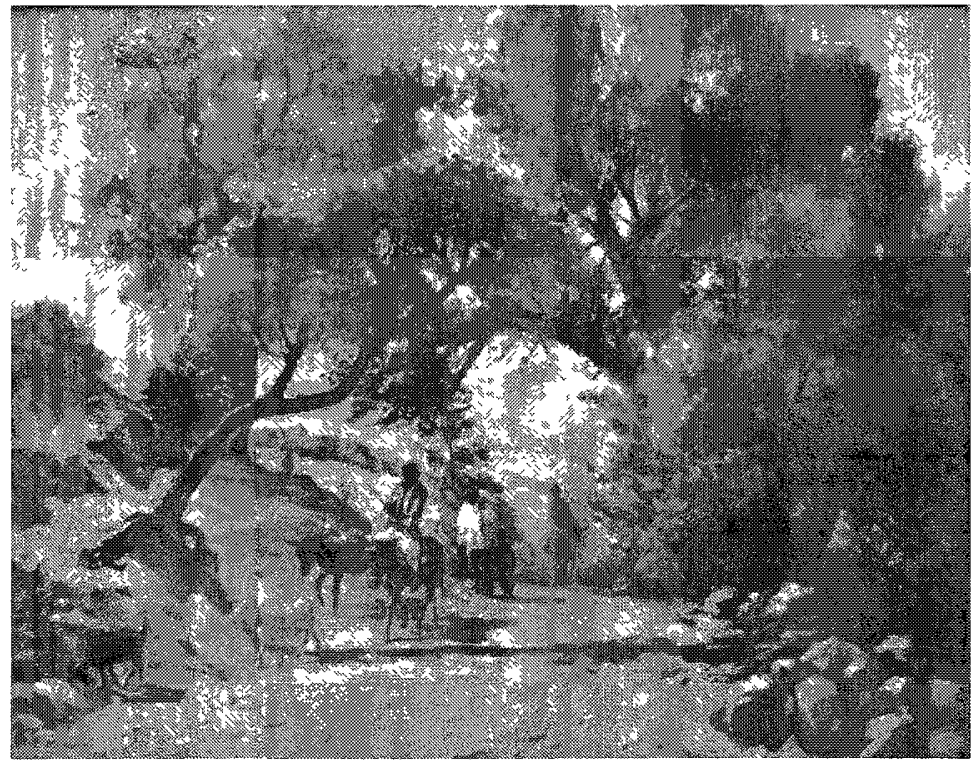

Figure 8 N.V. Kashina, Italy in the Khumsam (mountains in the Tashkent region), 1957 


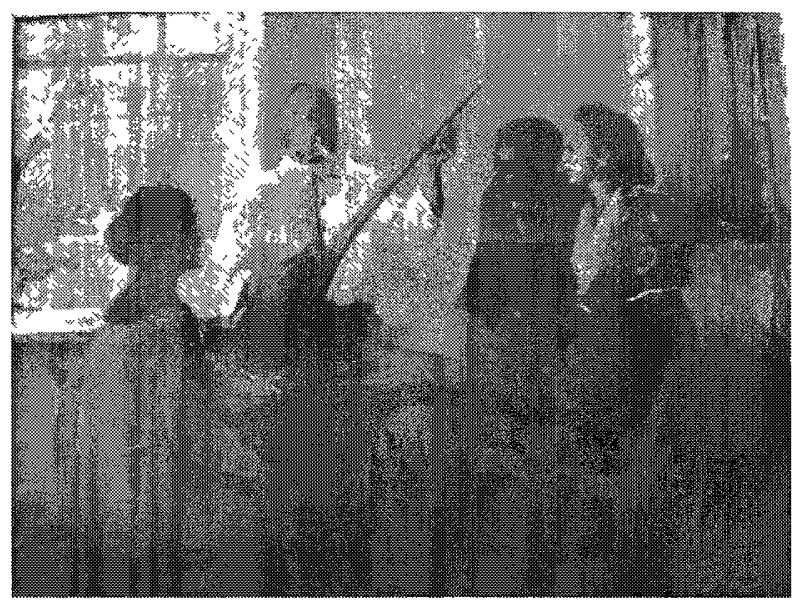

Figure 9 S.F Abduallaev, In the studio of Master Usman Zufarov, oil on canvas, 1958

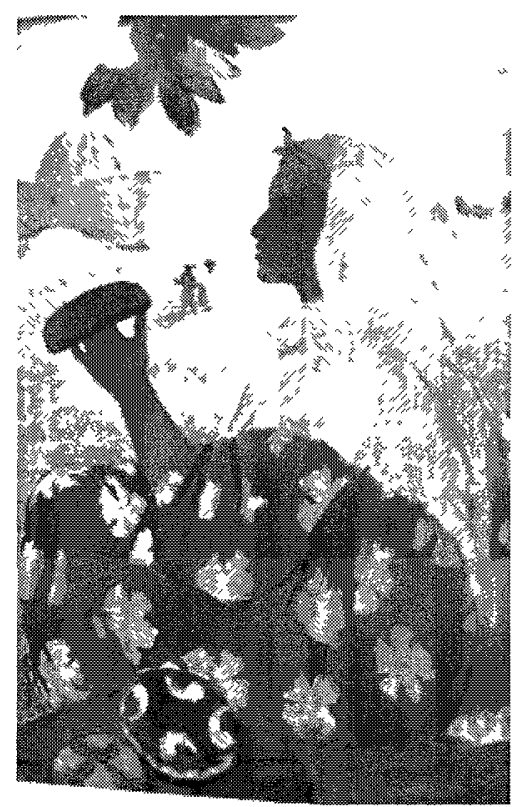

Figure 12 N.V. Kashina, A Small Skull Cap, oil \& wax on canvas, 1960 